\title{
CIVIC ARCHITECTURE \\ Empowering Ottawa's Unremarkable Urban Fragments
}

by

Tessa Kampman

A thesis submitted to the Faculty of Graduate Studies and Research in partial fulfillment of the requirements for the degree of

\section{Master of Architecture}

Carleton University, Ottawa, Ontario

May, 2011

Tessa Kampman 두 2011 


Library and Archives
Canada
Published Heritage
Branch
395 Wellington Street
Ottawa ON K1A ON4
Canada

NOTICE:

The author has granted a nonexclusive license allowing Library and Archives Canada to reproduce, publish, archive, preserve, conserve, communicate to the public by telecommunication or on the Internet, loan, distribute and sell theses worldwide, for commercial or noncommercial purposes, in microform, paper, electronic and/or any other formats.

The author retains copyright ownership and moral rights in this thesis. Neither the thesis nor substantial extracts from it may be printed or otherwise reproduced without the author's permission.
Bibliotheqque et

Archives Canada

Direction du

Patrimoine de l'édition

395 , rue Wellington

Ottawa ON K1A ON4

Canada
Your file Votre référence

ISBN: 978-0-494-81597-7

Our file Notre référence

ISBN: 978-0-494-81597-7

AVIS:

L'auteur a accordé une licence non exclusive permettant à la Bibliothèque et Archives Canada de reproduire, publier, archiver, sauvegarder, conserver, transmettre au public par télécommunication ou par l'Internet, prêter, distribuer et vendre des thèses partout dans le monde, à des fins commerciales ou autres, sur support microforme, papier, électronique et/ou autres formats.

L'auteur conserve la propriété du droit d'auteur et des droits moraux qui protège cette thèse. $\mathrm{Ni}$ la thèse ni des extraits substantiels de celle-ci ne doivent être imprimés ou autrement reproduits sans son autorisation.

In compliance with the Canadian Privacy Act some supporting forms may have been removed from this thesis.

While these forms may be included in the document page count, their removal does not represent any loss of content from the thesis.
Conformément à la loi canadienne sur la protection de la vie privée, quelques formulaires secondaires ont été enlevés de cette thèse.

Bien que ces formulaires aient inclus dans la pagination, il n'y aura aucun contenu manquant.

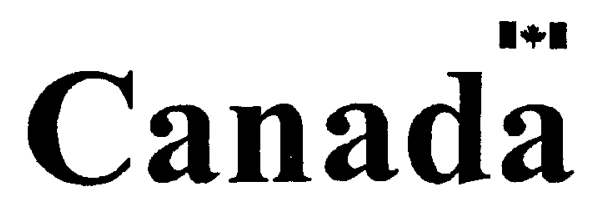




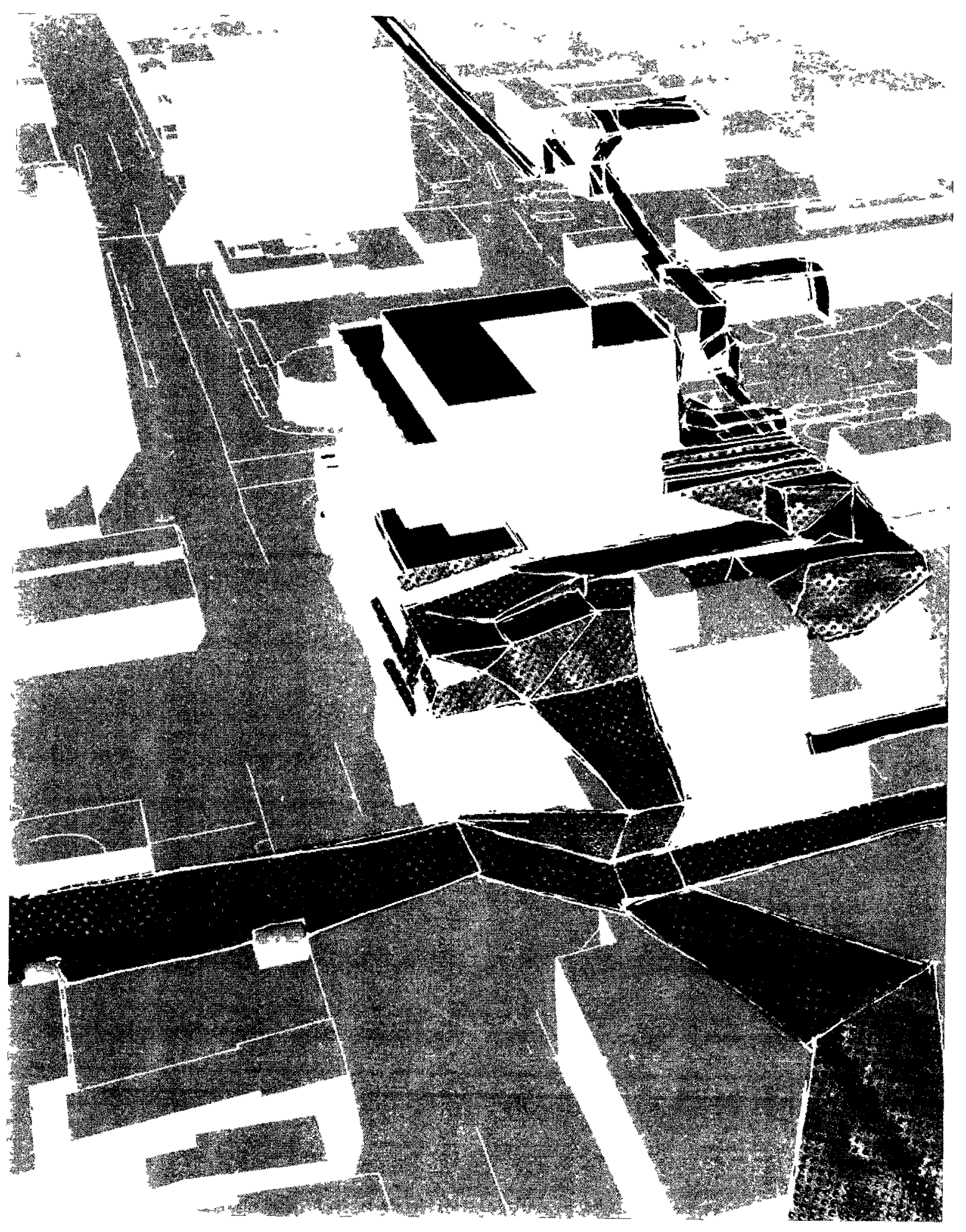

[Plate 1]

Frontispiece 


\section{[Abstract]}

This thesis proposes that the citizens of Ottawa should be able to recognize in the city's architecture a representation of their unique vibrant life and values - their civic identity. However, recent discourses in Ottawa suggest that what the citizens actually perceive are powerful emblems of national identity and a residual urban fabric that is unremarkable. In response to this bleak perception, this thesis develops a process for expressing civic identity through architecture. It investigates the reality of the city to discover the life that is currently hidden from view. It then relies on these discoveries to inspire architectural innovations intended to reveal this reality to the citizens. This process is tested in the proposal for the new Central Ottawa Library. The intention of the project is to create civic architecture that not only provides the citizens with one symbol of civic identity but transforms their perception of the entire urban fabric. 


\section{[Acknowledgements]}

Many thanks to Stephen Fai, for his helpful insights and suggestions but most importantly for his enthusiasm and encouragement, which inspired me to continue pushing forwards despite the uncertainty of the outcome.

I would also like to thank my fiancé, lan Carswell for his endless support, love, and marvellous cooking. Thank you to my parents, to my father Michael Kampman for the patience and energy with which he helped me work through my ideas and methodology, and to my mother Marcella Kampman for her unwavering faith in my success.

This project would also not have been possible without the generosity of those who assisted me with my research. I would like to thank the caretaker of the Seventh-day Adventist Church, architect Barry Padolsky, Hagit Hadaya and Laurie Dougherty from the Jewish Archives, Lt. Renée Jessop for escorting me around the Constitution Building, Stéphane Mainville for getting me the Constitution drawings, Gord Seymour from Dynar Architect \& Associates Inc., Jeff Copeland for finding the drawings of the Days Inn, and Bruce White for letting me measure the Bytowne Cinema.

To all my friends and family, thank you. 
[Table of Contents]

Title Page i

Frontispiece ii

Abstract iii

Acknowledgements iv

Table of Contents v v

List of Illustrations vi vi

List of Plates viii

List of Appendices $\quad$ ix

Introduction $\quad x$

Chapter 1

The Contemporary's Guide for Creating Civic Identity

Chapter 2

Reality from the Ottawa Peasant's Perspective

Chapter 3

Alchemy 101: Using Collage to Transform Worthless

Urban Fragments

Chapter 4

Ottawa's Urban Design Guidelines for Suppressing

Civic Identity

Chapter 5

A Proposal for the New Ottawa Central Library

Conclusion

Bibliography 


\section{[List of Illustrations]}

Figure 1 | Photographs comparing Ottawa's federal monuments xi to its "unremarkable" civic architecture Images by Author.

Figure 2 | Main Salon of Palau Guëll Lahuerta, Antoni Gaudi, 100.

Figure 3 | Diagrams of Tensions - Park Guëll Porticoes Lahuerta, Antoni Gaudi, 130.

Figure 4 I Sanctuary of the Colonia Guëll Crypt

Figure 5 | Stereostatic Model of Sagrada Familia Lahuerta, Antoni Gaudi, 215.

Figure 6 | Sketch of Sagrada Familia

Figure 7 Photograph of Rideau Street Image by Author.

Figure 8 | Adath Jeshurun Synagogue prior to 1922 Ottawa Jewish Archives 5-220

Figure 9 | Adath Jeshurun Interior in 1949

Figure 10| Francophone Seventh-day Adventist Church of Ottawa in 2010 Image by Author.

Figure 11 Constitution Building in 2011 Image by Author.

Figure 12 | Town House Motor Hotel - Perspective 1973 George E. Bemi, Architect.

Figure 13| Days Inn in 2010 Image by Author.

Figure 14 Nelson Theatre in 1947

Miguelez, A Theatre Near You, 275.

Figure 15 Fruit Dish and Glass - Georges Braque (1912)

Taylor, Collage, 16.

Figure 16 Still Life with Chair Caning - Pablo Picasso (1912) Warncke, Pablo Picasso, 81.

Figure 17| Squares According to the Laws of Chance - Hans Arp (c. 1917) Taylor, Collage, 39. 


\section{[List of Illustrations cont'd]}

Figure 18 | Dada Cino-Raoul Hausmann (1920)

Taylor, Collage, 43.

Figure 19| The Worker Picture - Kurt Schwitters (1919)

Taylor, Collage, 46.

Figure 20| Merzbau - Kurt Schwitters (c. 1930)

Dietrich, The Collages of Kurt Schwitters, 165.

Figure 21 Nate's Deli (August 26, 2010)

"Wreckers send remains of Nate's Deli into Ottawa's dusty memory." Photograph by Pat McGrath

Figure 22 New Shoppers Drug Mart

http://forum.skyscraperpage.com/showthread.php?t=177291

Figure 23| Helsinki's Consistent Urban Massing

City of Ottawa, Uptown Rideau, 12.

Figure 24| Kitchener City Hall - KPMB

Polo, "Mannered Modernism," 212.

Figure 25 Ottawa Central Archives - Ottawa Public Library Materials Centre 


\section{[List of Plates]}

Plate 1 | Frontispiece

Plate 2 | The Contemporaries 1

Plate 3 | The Urban Fabric 9

Plate 4 | The Urban Collage 19

Plate 5 | The Antithesis 29

$\begin{array}{lll}\text { Plate } 6 \text { | The Project } & 38\end{array}$

Plate 7 | Preserving the Urban Fabric 41

Plate 8 | Celebrating Collage Space 46

$\begin{array}{ll}\text { Plate } 9 \text { | Synthesizing the Fragments } & 49\end{array}$ 


\section{[List of Appendices]}

$\begin{array}{llr}\text { Appendix A | Plans } & 57\end{array}$

$\begin{array}{ll}\text { Appendix B | Massing Model Photographs } & 61\end{array}$

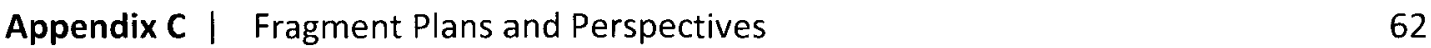

$\begin{array}{ll}\text { Concourse Atrium } & 62\end{array}$

Heritage Gateway $\quad 64$

Business \& Careers Centre and Language \& Literacy Centre 66

$\begin{array}{ll}\text { Welcome Centre } & 67\end{array}$

$\begin{array}{ll}\text { Teen Services } & 69\end{array}$

$\begin{array}{ll}\text { Community Library } & 70\end{array}$

$\begin{array}{ll}\text { Children's Services } & 71\end{array}$

Fiction, Newspapers \& Magazines $\quad 72$

$\begin{array}{ll}\text { Non-Fiction A } & 73\end{array}$

$\begin{array}{ll}\text { Non-Fiction B } & 74\end{array}$

Non-Fiction C $\quad 75$

$\begin{array}{ll}\text { Administration } & 76\end{array}$

Media \& Technology Centre $\quad 77$

$\begin{array}{ll}\text { Library Staff Spaces } & 78\end{array}$

Materials Handling \& Operations $\quad 80$

Appendix D | Sections $\quad 81$

Appendix E | Perspective 83 


\section{[Introduction]}

Architects have an obligation to design buildings that respond to the specific needs of the lives they are intended to harbour If architecture was intentionally designed to fulfill this obligation, then the uniqueness and vitality of the buıldıng's life would be evident in its form, functionalıty, and detaıls The building would be the physical expression of its inner life If all buildings in the city were designed in this way, then the city's urban fabric would express the full variety of its citizens' lives and values - Its civic identity The citizens would be able to recognize In the urban fabric their own reflection, which would inspire them to take pride in and ownershıp of their cIvIC architecture

Recent discourse in Ottawa suggests, however, that the citızens can recognize neither their Individual lives nor theır shared Identıty in the cıty's urban fabrıc Barbara Clubb and Elaıne Condos went so far in their New Central Library Functional Building Program report for the Ottawa Publıc Library Board as to state that the cıty's identıty has absolutely no architectural representation "Ottawa, whıle proud of the graceful Parlıament Buıldıngs and other federal Institutıons, is sıngularly lackıng in a symbol of city life - somethıng with symbolıc presence that provides a sense of cIvic identity where people go" ${ }^{1}$ Beyond confirmıng the city's lack of representation, this statement also introduces the reason for its neglect As a federal capital the city has allowed its great ambition to celebrate the identity of the nation to overshadow the need to express the values of its citizens The results of this negligence are summarized in an

\footnotetext{
${ }^{1}$ Barbara Clubb is the City Librarian and CEO of the Ottawa Publıc Library Elaıne Condos is the Divisıon Manager for Centralızed \& Informatıon Services City of Ottawa Ottawa Public Library Board, New Central Library Functional Building Program, prepared by Barbara Clubb and Elaıne Condos (Doc P1) (Ottawa Ottawa Public Library Board, June 10, 2009), 8
} 
interview with architect Rick MacEwan following his resignation from the Downtown Ottawa Urban Design Review Panel:

Imagine Ottawa without any of the property built and maintained by the federal government - Parliament Hill, the Rideau Canal, Vincent Massey and Gatineau Parks, the Experimental Farm, Rideau Hall and the River Parkways.

Now, remove any buildings older than 30 years old, the churches and the buildings in the Byward Market. 'The stuff you are left with is purely unremarkable. As an architect, that's a damning confession, but other cities do better than we do.'

The failure to recognize architecture's responsibility to the
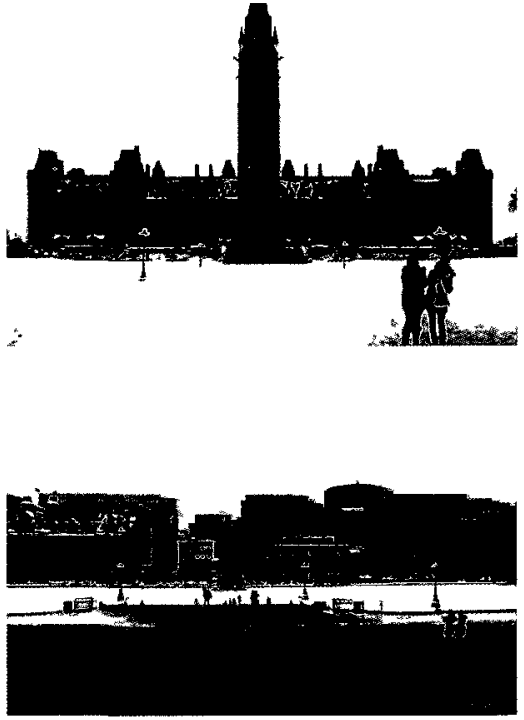

Figure 1 | Photographs comparing Ottawa's federal monuments to its "unremarkable" civic architecture - taken from the same location

citizens and the reliance on national monuments to represent their identity has resulted in a residual urban fabric that is "unremarkable": not only unable to inspire the citizens to remark but also incapable of remarking, or communicating, on their behalf.

This oversight demonstrates that it is not only the civic responsibility of architecture that has been disregarded but also the crucial role that regional architecture plays in the formation of the national identity. As Northrop Frye explains in his preface to The Bush Garden: Essays on the Canadian Imagination, "the question of Canadian identity: so far as it affects the creative imagination, is not a 'Canadian' question at all, but a regional question... identity is local and regional, rooted in the imagination and in the work of culture." ${ }^{3}$ Just as the city's identity is composed of the diverse values of its citizens, the nation's identity is formed by the unique cultures of its different regions. Therefore, by declining to reflect the local identity, Ottawa's

\footnotetext{
${ }^{2}$ Tim Wieclawski, "Design lost on city council, says architect," Metro Ottawa, December 9, 2009, accessed October 6, 2009, http://www.metronews.ca/ottawa/local/article/391895--design-lost-on-city-councilsays-architect.

${ }^{3}$ Frye quoted in Sherry McKay, "Ideas of Canadian Architecture," in Substance over Spectacle: Contemporary Canadian Architecture, ed. Andrew Gruft. (Vancouver: Arsenal Pulp Press, 2005), 198.
} 
architecture is also inadvertently undermining the national identity, whose representation has been the city's only architectural concern. In order to reverse these harmful effects and ensure that Ottawa's architecture has a positive impact on the development of both the civic and national identity, this thesis proposes that the city's architecture should fulfil its responsibility to the local citizens and work towards reflecting their civic life.

By emphasizing the importance of regional expression, this thesis participates in the discourse of "Critical Regionalism," which was first proposed by Alexander Tzonis and Liane Lefaivre in 1981 and later theorized by Kenneth Frampton in his Prospects for a Critical Regionalism. The thesis adheres to the basic principle of Frampton's Critical Regionalism, which is that architects should "represent and serve, in a critical sense, the limited constituencies in which they are grounded." ${ }^{4}$ However, it acknowledges the criticisms of Frampton's theory and challenges his notion that Critical Regionalism is the product of the tensions between universal modernism and rooted culture; ${ }^{5}$ it agrees instead with Richard Ingersoll's observation that, "the ever-changing elements of modernity are no longer in opposition to but become the fundamental reality of one's context." ${ }^{\prime 6}$ Architecture must strive to capture the city's "fundamental reality," rather than its romanticized traditions, in order to participate in "the progressive rise of hot culture." ${ }^{7}$ This reasoning follows Tzonis' own reassessment of Critical Regionalism, which led him to conclude:

that 'regionalism' is an unsatisfactory metaphor for a critical architecture that is complimentary to modern technological possibilities and performs competently for modern community formations and crossed out four letters turning the word into the more desirable concept of 'realism. ${ }^{8}$

\footnotetext{
4 Kenneth Frampton, "Prospects for a Critical Regionalism," Perspecta Vol. 20 (1983): 148.

5 Frampton, "Prospects for a Critical Regionalism," 149.

6 Richard Ingersoll, "Conference Review: Context and Modernity: Delft, June 12-15, 1990," Journal of Architectural Education (1984-) Vol. 44, No.2 (1991): 124.

7 Ingersoll, "Conference Review," 125.

${ }^{8}$ This quote is from a summary of Alexander Tzonis' presentation at the Context and Modernity conference by Ingersoll, "Conference Review," 125.
} 
It is, therefore, Ottawa's "realism" which this thesis attempts to uncover and represent through the project's architecture in order to create an accurate expression of the city's identity.

The first three chapters of the thesis deal with the question of how to achieve the architectural expression of Ottawa's civic identity. Chapter one reveals the process that will lead to the discovery of the city's reality and provides an example of how this can be effectively communicated using the language of architecture. It presents a general methodology for uncovering the reality of the present, which is guided by Giorgio Agamben's essay What is the Contemporary? It then proposes that, in order to represent the city's identity, the products of "Contemporary" investigation, the singular insights that reveal the obscurity of the present reality, ${ }^{9}$ must be used to inspire new architectural proposals. The chapter uses a case study of Antoni Gaudi's work in Barcelona to demonstrate how this process can generate extraordinary architectural innovations that are capable of redefining the identity of the city.

Chapter two appropriates this methodology for the specific purpose of revealing Ottawa's hidden civic reality. It explores Ottawa from the citizen's perspective, where one can actively engage with the city through all senses. Following the example of Louis Aragon's Paris Peasant, it interprets these sensual observations through reasoning to inspire a new mythological understanding of reality. The Ottawa Peasant's mythology exposes the importance of Ottawa's "unremarkable" urban fabric, which contains fragments of civic life imbued with the potential to express the city's identity. It demands that these fragments be preserved and permitted to speak on the citizens' behalf.

Chapter three describes the mechanisms that can empower Ottawa's urban discards to become the emblems of its civic identity. It describes how, through the alchemical properties of Cubist collage, the urban fragments can gain value and the capacity to project meaning. It

\footnotetext{
${ }^{9}$ Giorgio Agamben, "What Is the Contemporary?" in What is an Apparatus? and Other Essays (California: Stanford University Press, 2009), 44.
} 
further investıgates the descendents of collage, ıncludıng Zurıch and Berlın Dada, to discover the means with which to celebrate the fragments so that they are recognized by the citizens as representations of their own vibrant life Finally, a study of Kurt Schwitters' Merz works reveals methods for synthesizing the fragments to create a unified visıon that can shape the future of the city's Identity

The first three chapters of the thesis lead to the conclusion that Ottawa architecture should preserve, celebrate, and create the city's unique identity The fourth chapter compares these new priorities with the current state of Ottawa's urban development to highlight Inconsistencies, which pinpoint the causes of the city's current lack of architectural identity The chapter establıshes that Ottawa's identity crisıs is caused by the city's destruction or avoidance of its important urban fragments, its idolatry of foreign forms of cIVIc identity that conflict with Its own reality, and its dependence on "Mannerist Modern" architecture, which has lost all social relevance, ${ }^{10}$ to represent its identity

Chapter five documents the design project, which responds to the Ottawa Public Library Board's petition for a "Central Library" to "provide a distınguished city landmark, a symbolic presence and a sense of civic Identity "11 The desıgn exploits the prodigıous importance of the new Central Library project to draw attention to the urgent need to preserve and celebrate the city's existıng fabric and to create a new vision for the identity of the city, one which is born out of the citizens' reality and values The intention of the project is to not only provide the city with one solitary symbol of civic identity but to elevate the symbolıc potential of the entire urban fabric, so that it may be cherished by the citizens and become a source of cIVIc pride

\footnotetext{
10 Marco Polo, "Mannered Modernism Fifteen Years of Canadian Architecture," In Substance over Spectacle Contemporary Canadian Architecture, ed Andrew Gruft (Vancouver Arsenal Pulp Press, 2005), 217

${ }^{11}$ City of Ottawa Ottawa Public Library, New Central Library Functıonal Buıldıng Program, Resource Plannıng Group Inc (Confıdentıal Fınal Draft) (Ottawa Ottawa Publıc Lıbrary, March 2009), 3
} 


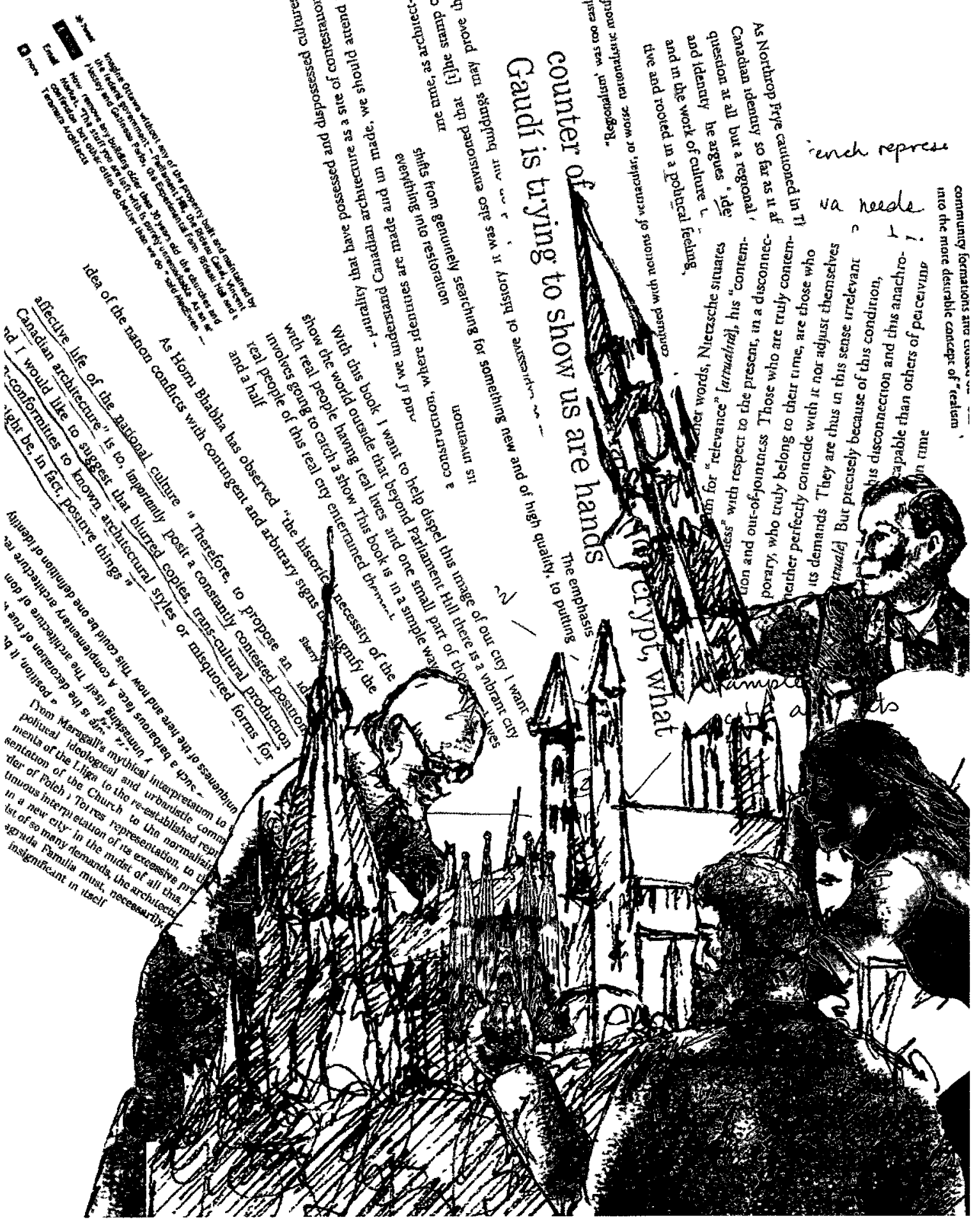

[Plate 2]

The Contemporaries

Enlisting the Help of Gaudi, Berlage and Aalto 


\section{[Chapter 1]}

\section{The Contemporary's Guide for Creating Civic Identity}

The statement of the Ottawa Public Library Board and the confession of local architect Rick MacEwan suggest that the citizens of Ottawa are dissatisfied with their current civic representation. They feel that the city's architecture is unexceptional and has fallen short of expressing their vibrant life. This bleak perception of Ottawa's condition cannot go unheeded; instead an effective process for its remediation must be implemented. This process involves uncovering the reality of the civic identity and developing innovative methods for its reflection that inspire the citizens to recognize in the city's architecture their own likeness, culture, and values. This recognition will encourage the citizens to find satisfaction in their urban fabric and its representation of their civic identity.

In order to accurately represent Ottawa's identity, local architects must come to an authentic and comprehensive understanding of the city's present reality. To this effect they must be truly "contemporary." In his essay What is the Contemporary? Giorgio Agamben outlines the different attributes of the contemporary: the qualities that can empower Ottawa architects to fully understand the unique nature of their own time and place. He demonstrates the necessity of being detached from the conventional understanding of the present in order to be contemporary:

Those who are truly contemporary, who truly belong to their time, are those who neither perfectly coincide with it nor adjust themselves to its demands... But precisely because of this condition, precisely through this disconnection and this anachronism, they are more capable than others of perceiving and grasping their own time. ${ }^{12}$

\footnotetext{
${ }^{12}$ Agamben, "What Is the Contemporary?" 40.
} 
Agamben explains that from this disjointed position the contemporary is able to see the "obscurity of the present," ${ }^{13}$ that which has gone unnoticed by others, and to perceive withın this darkness the "light that strives to reach us but cannot "14 But beyond merely understandıng the present, the one who is contemporary can also forge connections between different eras since "he is also the one who, dividıng and Interpolatıng tıme, is capable of transforming it and puttıng it in relation with other tımes"15 Therefore, by observing Ottawa from the unconventional vantage of being contemporary, an architect can capture the obscurity of the city's past and present and Illumınate it through architectural projection, enablıng the citizens to recognize the light of their own civic identity that was previously unable to reach them

The Illumination of contemporary insights into the present cannot be achieved through obsolete architectural means, instead they must be used to inspire architects to generate alternate, innovative methods for civic expression This new architectural language will differentiate the identity of the city from others and provide the citizens with a source of civic pride In Architecture in Transition From Art to Practice, Kelly Crossman advances the Importance of innovation in the creation of identıty "[t]he stamp of originality which we hope will be placed on our bullıngs may prove that Canada is a natıon"16 By placıng the "stamp of orıgınalıty" on the city's architecture, local architects may prove that Ottawa has a distınct cıvic Identıty Therefore, the power of architectural ınnovatıon comes not from pursuing origınalıty for its own sake, but from providing the citizens with a new expression of civic identity, one that they will take ownership of because it was inspired by their own unique civic life

One example of an architect who was able to achieve this level of originality in civic architecture, who was able to not only capture the identity of the citızens but also reflect their

\footnotetext{
${ }^{13}$ Agamben, "What Is the Contemporary" 44

${ }^{14}$ Agamben, "What is the Contemporary?" 46

${ }^{15}$ Agamben, "What is the Contemporary?" 53

${ }^{16}$ Crossman quoted in McKay, "Ideas of Canadıan Archıtecture," 196
} 
spirit in bold architectural innovations, is Antoni Gaudí. A study of Gaudi's work in and around Barcelona reveals that his process for creating civic identity is analogous to that proposed in this chapter. His work therefore demonstrates how, by being truly contemporary and developing revolutionary methods for expressing the hidden reality of the present, it is possible to redefine the identity of a region. The impact of Gaudi's work and its ability to create civic identity are affirmed by the texts of the Catalan poets, writers, and critics of his time.

Juan José Lahuerta relies on these original texts to present a multifaceted understanding of Gaudi's work in Antoni Gaudi 1852-1926: Architecture, Ideology and Politics. Lahuerta establishes Gaudís contemporary position, outside of the present, through his interpretation of Frederic Rahola's evaluation of Palau Guëll: "Rahola says of Gaudí that his constructions battle against routine and fashion. Against the flat, constant and mediocre time of the everyday and of habit, but also against the ever-changing, always 'other' time

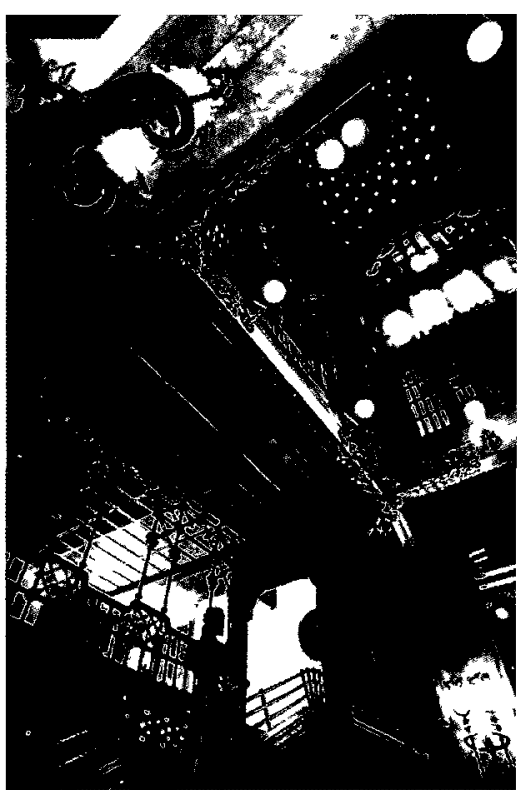

Figure 2 | Maın Salon of Palau Guell of fashion."17 This position is further reinforced by Lahuerta's explanation of Gaudi's intentional overuse of material and labour in the Palau: "the object is to be not modern but anachronistic."18 ${ }^{1 \mathrm{t}}$ is this detachment from the present which allowed Gaudi to singularly grasp the hidden qualities of Catalan culture and perceive new methods for its representation.

As a true contemporary, Gaudí was able to move beyond the reliance on established emblems for portraying Catalan identity and discovered new methods for conveying its more

\footnotetext{
17 Juan José Lahuerta, Antoni Gaudí 1852-1926: Architecture, Ideology and Politics (Milano: Electa Architecture, 2003), 88.

${ }^{18}$ Lahuerta, Antoni Gaudi, 61.
} 
"obscure present." One of these well established emblems was Catalonia's medieval past, which according to Lahuerta had already become, "the motif and symbol of the restoration of the country's greatness." ${ }^{19}$ In the numerous artworks and sculptures that enriched the interior and exterior detailing of his early works, Gaudi injected multiple medieval and mythical references that resonated with the bourgeoisie. Frederic Rahola was particularly affected by the Palau Güell and his writing reveals that for him, "the Palau Güell is literally neither more nor less than the spirit of Catalonia made flesh and blood, incarnate." ${ }^{20}$ In later projects, however, Gaudi developed unique and innovative methods for expressing the more obscure facets of the region's identity. For Park Güell he designed grand porticoes that doubled as retaining walls, whose sculptural form perfectly corresponded to the lines of its tensional diagram that began not at, but from, the earth. For Gaudi's collaborator Joan Rubió i Bellver these porticoes represented integrity; they were the product of the earth's laws and were equally rational. ${ }^{21}$ In his writing, Rubio declares that these porticoes are the manifestation of the Catalan spirit: "sculptural form, stony creation, visible and palpable manifestation of our innovative and practical, idealistic and scientific spirit, fond of soaring to distant horizons and enamored of simple and practical means for obtaining grand effects." 22 This likeness to the regional spirit is not only

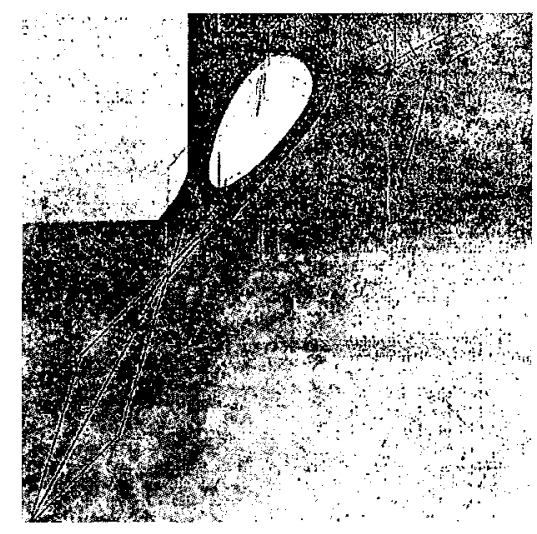

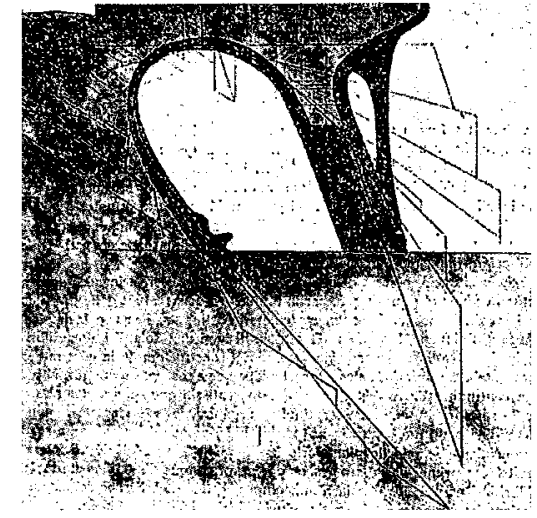

Figure 3 | Diagrams of Tensions Park Guëll Porticoes

\footnotetext{
${ }^{19}$ Lahuerta, Antoni Gaudi, 22.

${ }^{20}$ Lahuerta, Antoni Gaudi, 103.

${ }^{21}$ Lahuerta, Antoni Gaudi, 131.

${ }^{22}$ Lahuerta, Antoni Gaudi, 130.
} 
created by the porticoes' form but by their deeply rooted connection to the soil, which poet Joan Maragall had claimed was the source of a people's soul.

According to Maragall the soil of Catalonia made the people, "accustomed to triumph through work," because, "the Catalan earth is hard, but grateful."23 Gaudí developed architectural details that celebrated the labour of Catalan hands for his design of the church crypt for Colonia Güell: the worker's community for Güell's corduroy factory just outside Barcelona. In the crypt, which eventually became the church proper, Gaudí used intentionally crude and brutal joining

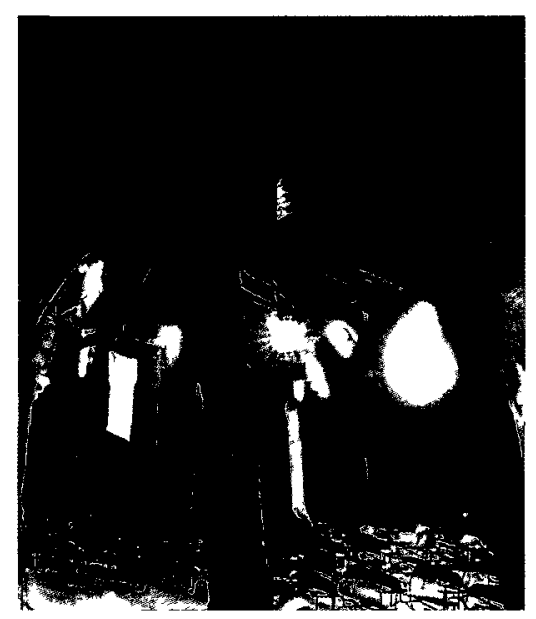

Figure 4 | Sanctuary of the Colonia Guëll Crypt

techniques, incorporated over-fired bricks in visible areas, and repurposed needles from the factory's weaving machines to create a hexagon mesh for window screening. According to Lahuerta these unorthodox details show, "The immediacy of work represented as force, as pain." 24 He reveals Gaudís intentions by writing, "In each trace, in each wound, in the difficult encounter of each of the materials in the crypt, what Gaudí is trying to show us are hands." 25 From these examples it is clear that Gaudi's innovative structural forms and his unconventional use of material were the result of his tenacious aspiration to express the complexity of the Catalan identity.

Gaudi's imaginative reinterpretation of Gothic architecture demonstrates another contemporary quality: his ability to manipulate time and create new relationships with past eras. His critical questioning of Gothic architecture was nurtured by his early employer, Joan Martorell, who was opposed to the "archaeologism" of the academy's Gothic Revival and

\footnotetext{
${ }^{23}$ Lahuerta, Antoni Gaudi, 131.

${ }^{24}$ Lahuerta, Antoni Gaudi, 209.

${ }^{25}$ Lahuerta, Antoni Gaudi, 209.
} 
advocated instead a "modern Gothic" style. Under Martorell, Gaudí and a group of other young architects attempted to regenerate Gothic architecture by correcting its structural imperfections and freeing its decorative language to accept multiple sources of inspiration. They improved on the Gothic structural system by devising the parabolic vault, which eliminated the outward thrust of the pointed Gothic arch. Gaudi, however, distinguished himself from the group by taking their new formal language to "almost unrecognizable

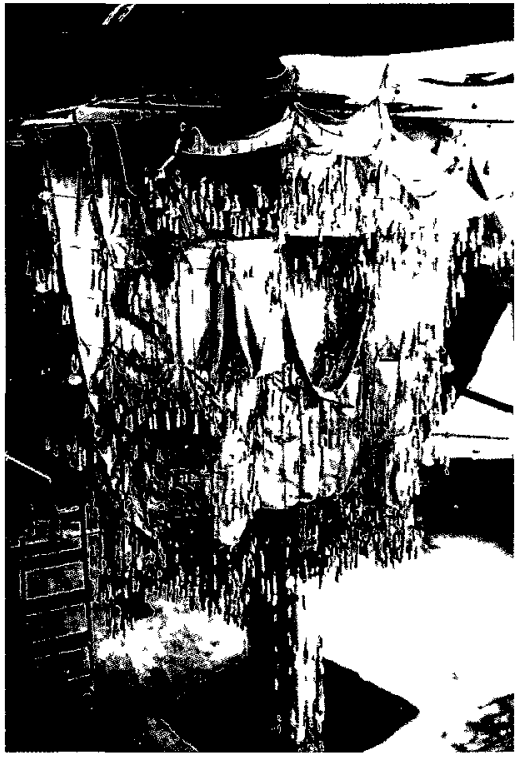

Figure 5 | Stereostatic Model of Sagrada Familia extremes." ${ }^{26}$ He exploited the full potential of the parabolic arch in the development of his stereostatic model, which calculated and balanced the loads in a system of interconnected arches that were represented by strings loaded with bags of lead pellets. It was on these new models that Gaudí based his design for his largest and most prominent work, the Sagrada Familia. By building on the foundations of Gothic architecture and drawing from it the inspiration for his revolutionary structural systems, Gaudi forged a strong connection between Catalonia's cultural past and his new vision for its future.

Through his veneration of the past and his belief in architecture's civic purpose, Gaudí differentiated his work from his "Modernista" contemporaries. Modernisme, which was the dominant architectural style in Barcelona during Gaudi's time, was the Catalan version of the international Art Nouveau and Jugendstil movements that attempted a total break with traditional architecture. ${ }^{27}$ Gaudí opposed Modernisme's disregard for architectural tradition as well as its superficial notion of art pour l'art. Along with the other members of the Cercle Artistic de Sant Lluc, Gaudi saw his art as part of a religious and social restoration. The Cercle

\footnotetext{
${ }^{26}$ Lahuerta, Antoni Gaudí, 32.

${ }^{27}$ Lluis Permanyer, Gaudi of Barcelona, (New York: International Publications, Inc., 1997), 7.
} 
believed in the idea of "an objective art... that was recognizable not in its own right but as a functional part of a plan." 28 Through his endeavour to create purposeful architecture, which was inspired by the region's past and worked to reveal its hidden present, Gaudi distinguished his work from all others.

His "stamp of originality" possessed the individuality to redefine Catalan identity and the depth to represent the complex reality of the citizens, enabling them to recognize in his work their own likeness. Lahuerta demonstrates in his conclusion of Antoni Gaudi 1852-1926 that the true legacy of Gaudís Sagrada Familia is the creation of a new sense of civic identity that was so effectively established that, in the end, the building itself was immaterial:

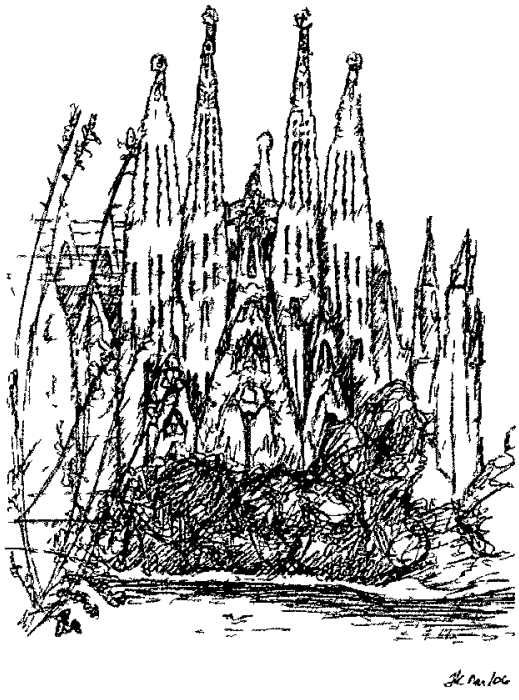

Figure 6 | Sketch of Sagrada Famılı

From Maragall's mythical interpretation to the political, ideological and urbanistic commitments of the Lliga, to the re-established representation of the Church, to the normalizing order of Folch i Torres' representation, to the continuous interpretation of its excessive presence in a new city: in the midst of all this, in the midst of so many demands, the architecture of the Sagrada Familia must, necessarily, be irrelevant, insignificant in itself. ${ }^{29}$

It is this level of insignificance that Ottawa architecture should strive to achieve. Civic architecture cannot be realised by buildings designed purely for their own self promotion and glorification. On the contrary it is created by the desire to capture the citizens' imagination, inspiring them to take pride in their civic identity and interest in how it is reflected in their urban fabric.

\footnotetext{
${ }^{28}$ Lahuerta, Antoni Gaudi, 224.

${ }^{29}$ Lahuerta, Antonı Gaudi, 312.
} 
[Chapter 2] |9

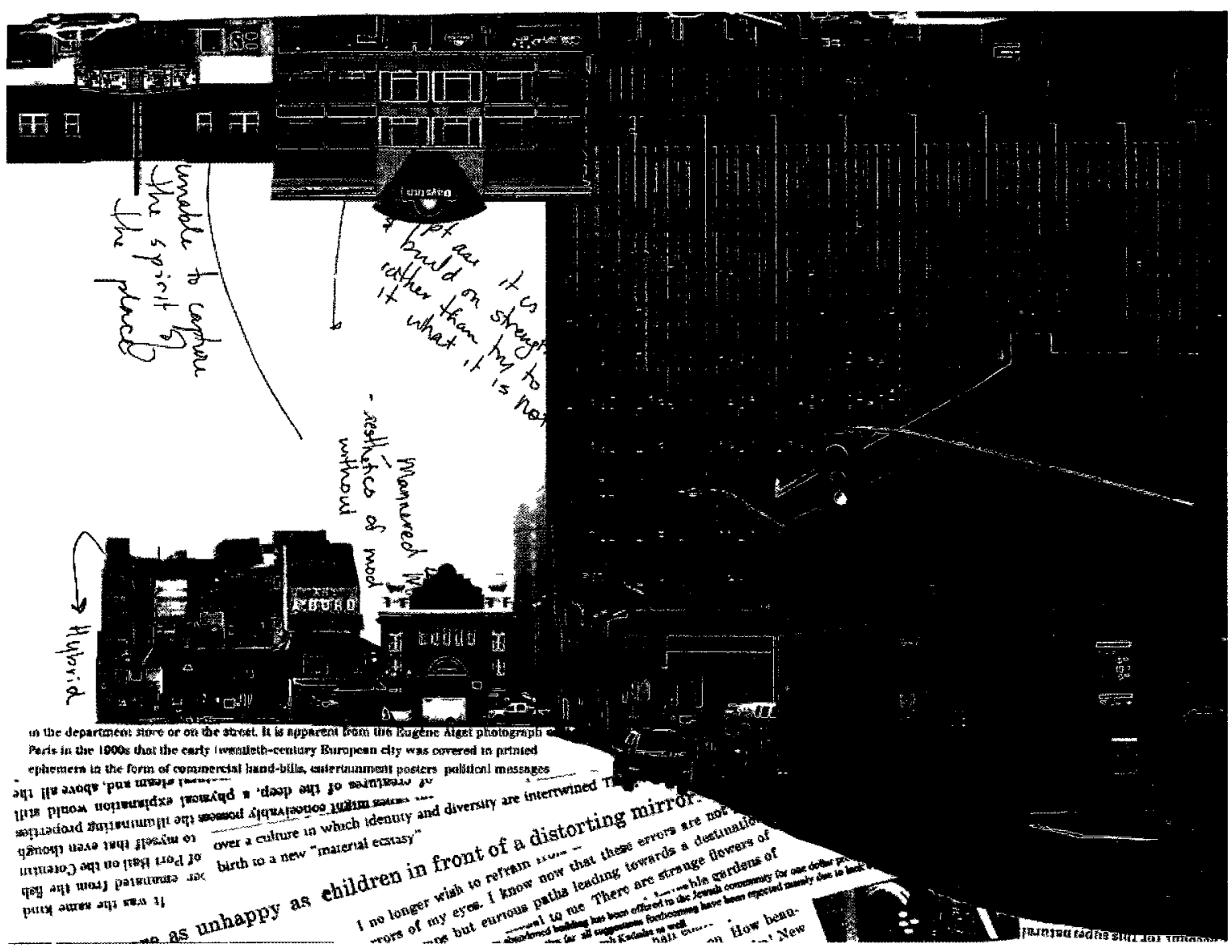

\section{[Plate 3]}

The Urban Fabric 


\section{[Chapter 2]}

\section{Reality from the Ottawa Peasant's Perspective}

To discover Ottawa's obscure reality, the lessons of the contemporary must be adapted to suit the city's unique condition. The inability of citizens to perceive any symbol of civic life on the surface of the urban fabric confirms that the reality of the city is currently hidden from the view of those, "who coincide too well with the epoch, those who are perfectly tied to it in every respect. ${ }^{30}$ It is clear that in order to discover Ottawa's civic identity, architects must view the city through the lens of the contemporary in order to overcome this superficial perception of reality. Because the element that is currently missing from the city's architectural presence is the vibrant life of the citizens, it is from their intimate perspective that this investigation should take place. From this modest pedestrian vantage point, contemporary architects can engage with the city through all the senses and can use their unconventional insight to generate from these observations a new understanding of the city's obscure reality. This method for revealing hidden realities from sensual experiences is demonstrated by Louis Aragon in Paris Peasant.

In his Preface to a Modern Mythology, Aragon explains the thought processes that inspired him to write Paris Peasant. At that time, in 1924, he was critical of the predominant procedure for developing philosophical thought, which favoured certainty and reason over error and sensorial experience. Instead, his reflections led him to the realization that, "neither the senses nor reason can be apprehended separately from each other." ${ }^{31}$ Upon concluding that sensitive error should not be considered subordinate to human reason, Aragon decided to allow

\footnotetext{
${ }^{30}$ Agamben, "What Is the Contemporary?" 41.

${ }^{31}$ Louis Aragon, Paris Peasant (Boston: Exact Change, 1994), 10.
} 
the senses and their inherent errors to take on leading roles in the development of his reasoning:

I no longer wish to refrain from the errors of my fingers, the errors of my eyes. I know now that these errors are not just booby traps but curious paths leading towards a destination that they alone can reveal to me. There are strange flowers of reason to match each error of the senses... New myths spring up beneath each step we take... Each day the modern sense of existence becomes subtly altered. A mythology ravels and unravels... ${ }^{32}$

By encouraging his powers of reasoning to act upon sensorial misinformation, Aragon conjured mythology from everyday experiences.

Aragon's modern mythology is described in meticulous detail in The Passage de l'Opéra, the first chapter of Paris Peasant. Here Aragon carefully composes an authentic and vivid depiction of street life in the ill-fated landscape of covered arcades, or "human aquariums," soon to be demolished to provide access to the Boulevard Haussmann. When Aragon has exhausted all information absorbed by the senses, he shifts imperceptibly into a narrative daydream following his mental journey from reason to myth. In one such instance his illustration of an ordinary cane shop and its wares becomes interwoven with memories of the sea to a point where he recognizes a siren floating in the window display among the canes. ${ }^{34}$ Later in the chapter he is berated for writing this account by a woman who is outraged by the embarrassment and confusion Aragon's writing has caused the local people. She explains that the locals "find it impossible to disentangle what is pure invention from what purports to be a recording of their views, and so they are as unhappy as children in front of a distorting mirror." ${ }^{35}$ The woman is frustrated not by Aragon's observations or imaginative ramblings but by the new

\footnotetext{
${ }^{32}$ Aragon, Paris Peasant, 10.

${ }^{33}$ Aragon, Paris Peasant, 14.

${ }^{34}$ Aragon, Paris Peasant, 22.

${ }^{35}$ Aragon, Paris Peasant, 85.
} 
mythology he has created, one which is contradictory to her own. His new mythology depicts a reality made from the interweaving of "pure invention" and factual representation.

Although the woman misunderstands it as a trivial, and even malicious, flight of fantasy, Aragon's modern mythology is the product of his attempt to express a more complete understanding of reality. Upon embarking on his enterprise to allow the errors of the senses to manipulate reason, he immediately realised its potential: "Thus, for the first time, I found myself advancing deliberately along the conscious path of what I later came to call realism." ${ }^{36}$ Aragon's notion of realism is more inclusive than those based on reason alone; it not only accepts but takes advantage of the human experience, which is informed by flawed information from the senses and is constantly distracted by the unpredictable trajectory of the imagination. Because Aragon's realism ventures beyond the conventional understanding of reality it is considered to be above realism - Surrealism. By following in his "conscious path," the contemporary Ottawa architect can likewise push beyond the superficial perception of reality in order to capture the full complexity of the city's "surreality."

To pursue Aragon's path, the contemporary Ottawa architect must explore the city from the Ottawa Peasant's vantage point and absorb all the richness of the information gathered by the senses. In the eyes of the Ottawa Peasant, who has not yet lost the "taste and texture of the unwonted, [sic] the unthought of, ${ }^{\prime 37}$ the city exhibits a wealth of sensual experiences waiting to be explored. However, these explorations into the city's vibrant life cannot take place amidst the federal monuments on Parliament Hill, where the only sign of life is the lone protestor who increases his efficacy by holding a sign that reads "Stop Persecuting Immigrants" on one side and "Stop Wasting Taxpayer's Money" on the other. The search for civic vital signs must move deeper into the urban fabric, past the architectural landmarks on Wellington Street

\footnotetext{
${ }^{36}$ Aragon, Paris Peasant, xiv.

${ }^{37}$ Aragon, Paris Peasant, 11.
} 
and the mausoleum of civic life that was Union Station. It is just beyond the transit station on Rideau Street, the chasm that is bounded by the blank facades of the Rideau Centre and The Bay, where the faint pulse of civic vitality begins to reveal itself. It is here that the discovery of Ottawa's civic life can commence.

In this most westerly section of Rideau Street, one can observe the innumerable variations and idiosyncrasies that contribute to the sensual complexity of Ottawa's civic life. Here there are shops selling everything from howling wolf figurines and moose-shaped mugs to bongs and pipes in

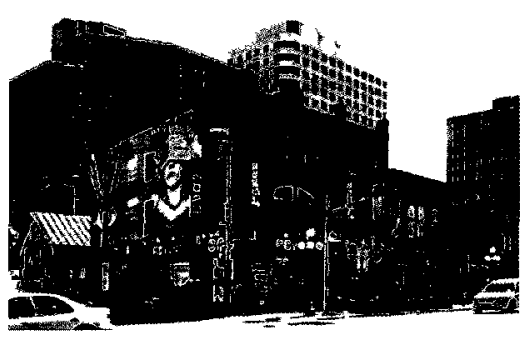

Figure 7 | Photograph of Rideau Street all varieties of colour and size. There is a clothing shop that specializes in "premium" clothing where the second item costs only one dollar, a piercing studio that offers two piercings for the price of one on Mondays, and an internet café that moonlights as a karaoke bar. Reputable banks and cafés are intermingled with tattoo parlours and hair salons that advertise their ability to braid any shape into the customer's head.

Here the variety of products and services offered to the citizen is only surmounted by the deviations in the massing and form of the buildings that house them. Old three-storey warehouses and their modern doppelgangers are butted up against small temporary structures in glass and metal that share walls with tall brutalist office towers or mundane condominium structures. This eccentrically composed streetscape appears to obey Aragon's "laws of divergence," which he describes as the statutes of "God's imagination: an imagination attuned to infinitesimal and discordant variations, as though the great question was to bring together, one day, an orange and a piece of string, a wall and a glance." In this section of Ottawa, one can 
find all of the stage props that Aragon claims are used by God in His still-life arrangements, "the absurd, the trumpery, the banal." 38

Looking to a broader scope, however, one will notice that these still-lifes of discordant urban fragments are not confined to this one section of Ottawa alone. They permeate the city and are evident throughout its neighbourhoods. They are a dominant feature in the urban landscape and compose the majority of the citizen's field of view. As such, these urban compositions are integral to the understanding of Ottawa's reality from the pedestrian perspective and require further investigation, at an even more intimate level. At the corner of Rideau and King Edward Streets, where the vibrant neighbourhoods of Lower Town, Sandy Hill, and Downtown Rideau all converge, there is an intriguing still-life in which absurdity, trumpery, and banality are all shamelessly present.

At the north end of this composition is an old synagogue from 1904 that is ornamented with Romanesqueinspired rounded windows and Moorish onion domes. These details were designed by British immigrant architect John W. H. Watts and composed into a curious eclectic historicist style in an attempt to convey a feeling of nostalgia and remembrance for the Eastern-European Jewish congregation, "to serve as a comforting link to the world they had left

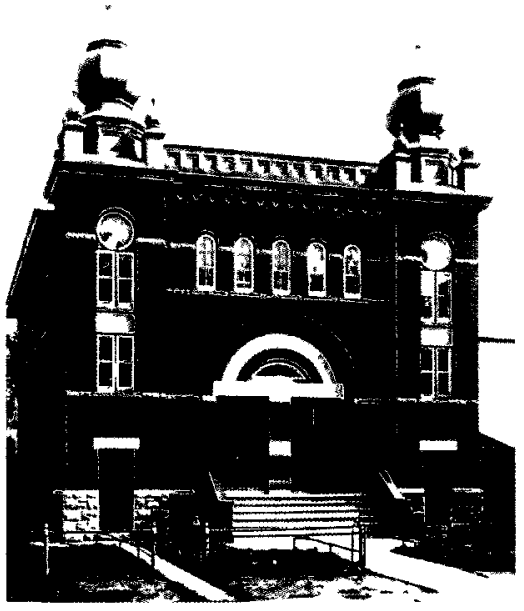

Figure 8 | Adath Jeshurun Synagogue prior to 1922 behind." ${ }^{39}$ This eclecticism is even more confused on the interior, where Watts introduced Arts and Crafts wood carvings, inspired by his English architectural training. ${ }^{40}$ The building was

\footnotetext{
${ }^{38}$ Aragon, Paris Peasant, 47-48.

${ }^{39}$ Hagit Hadaya, "The First Synagogues in Ottawa," Society for the Study of Architecture in Canada Bulletin Vol. 19, No. 2 (1994): 82.

${ }^{40}$ Hagit Hadaya, "Lack of Parking May Doom Ottawa's Oldest Synagogue," Jewish Heritage Report Vol. II, No. 1-2 (1998)
} 
originally intended for Ottawa's first Jewish congregation, Adath Jeshurun, who is rumoured to have come to Ottawa on account of the city's low peddling fees. ${ }^{41}$ Over time, however, the inhabitants have changed; in 1953 it was sold to the Chevra Kadisha to serve as a funeral chapel, and at the end of 1997 it was abandoned. At this time the building was

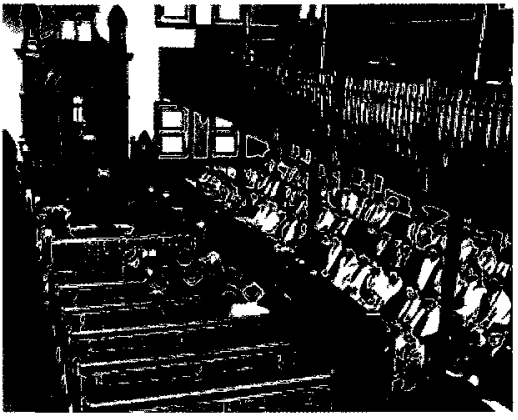

Figure 9 | Adath Jeshurun Interıor in 1949

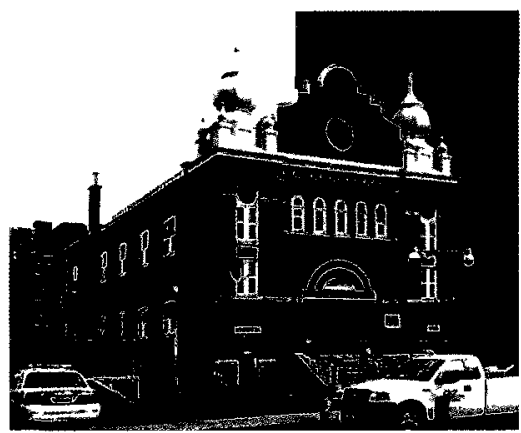

Figure 10 | Francophone Seventh-day Adventist Church of Ottawa in 2010 immigrant population. The congregation has been increasing in number and is now overwhelming the small building. Although the building shows the telltale signs of past additions, including a seam on the side walls that betrays an addition to the length in 1922 and a decorative gable end that was made to conceal a new pitched roof addition in 1930 , it appears as though more additions may be required if the congregation is to remain.

Directly south of the synagogue, and looming heavily above, is an eleven-storey office tower from 1963 that often appears completely devoid of any vital signs. Its windows at streetlevel are white-washed to block the view of pedestrians, and to protect against any that might venture inside, there is an immediate blockade of turnstiles in the lobby to reject unwelcomed visitors. There is one anomaly however in the building's otherwise unwelcoming facades; on the south side there is the small Union Smoke Shop that has a barber shop in one corner of its retail space. This building is currently used for laboratories and offices for the Department of National

\footnotetext{
${ }^{41}$ Hadaya, "The First Synagogues in Ottawa," 78.

42 Hadaya, "Lack of Parking May Doom Ottawa's Oldest Synagogue."
} 
Defence, who was lured here by the attractive low rental rates that accompany office buildings "within B plus or B government classification." ${ }^{43}$ From the exterior it is possible to perceive the amount of work that was done to sustain this level of mediocrity; in 1985 all pre-cast panels were washed, all single-glazed windows were replaced with double-glazed

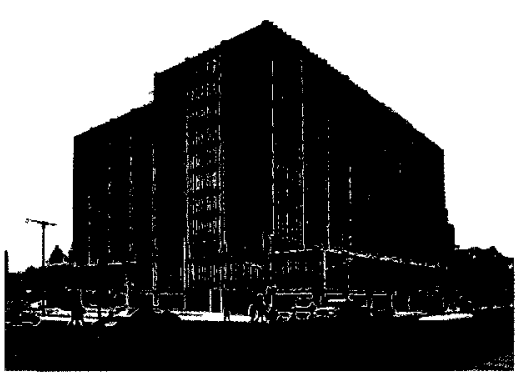

Figure 11 | Constitutıon Buıldıng in 2011

units, and insulation was installed in the exterior walls. ${ }^{44}$ Despite all this, the Department of National Defence may be vacating these premises as part of a restructuring that involves the relocation of many of their downtown offices outside of the city core.

To the east of the Constitution Building is the Days Inn, which was designed in 1960 by George E. Bemi and was originally the Town House Motor Hotel. Bemi's modernist design was articulated with clean lines and large expanses of glass on the front facade. The design featured suites with equally modern interiors and multiple amenity spaces,

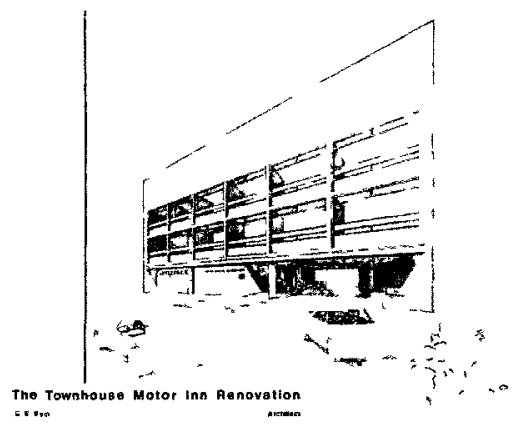

Figure 12 | Town House Motor Hotel Perspective - 1973

including a sun deck, meeting rooms, and the "Gourmet Room," which was a fine dining restaurant known for its live lobster tank. The building has had several additions and alterations over the years, including one renovation by Bemi in 1973, which were executed in order to maximize the

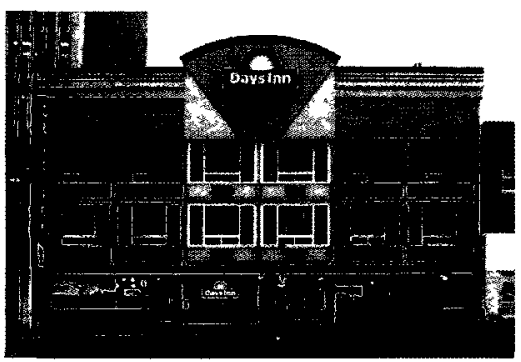

Figure 13 | Days Inn in 2010 number of suites. Over the years the covered parking area, storage rooms, meeting spaces, and sun deck have all been converted into additional hotel rooms. The restaurant space has also

\footnotetext{
${ }^{43}$ David Lees, Capital Realty Management Corp.: Constitution Building (Rideau) (Ottawa: Royal LePage, 1985), 3.

${ }^{44}$ Lees, Capital Realty Management Corp., 16.
} 
experienced numerous renovations and is currently occupied by the Maru Korean Restaurant. When the building was converted into a Days Inn franchise, a process of de-modernization and re-branding began that entailed the construction of arched parapets and the repainting of the facades, which are now shrouded in a pastel palette of peach and beige.

The Town House Motor Hotel was owned by Hyman Berlin, who also built the neighbouring Nelson Theatre in 1947. Because the hotel was built directly abutting the theatre, the two buildings share a stairwell that connects the hotel stairs with the theatre's balcony fire exit. The Nelson

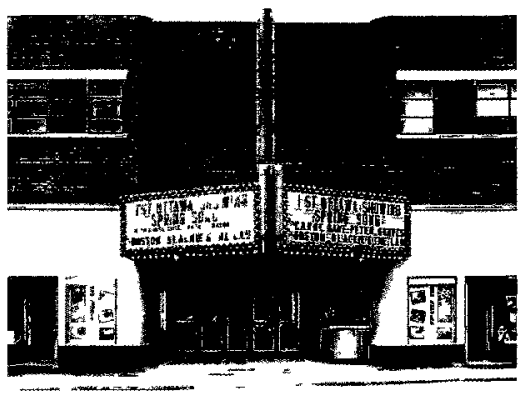

Figure 14 | Nelson Theatre in 1947 Theatre was run by Berlin for only five years, after which it was leased to Famous Players. In 1988 the theatre was sold to Bruce White, who renamed it the Bytowne. Throughout the building's lifetime, only minimal changes have been made; the windows have been replaced and the sign and terrazzo flooring have been altered to say "Bytowne" instead of "Nelson." In order to keep the original marquee, which did not comply with city bylaws, the owner continues to pay annual municipal encroachment fees for overhanging a public right-of-way. ${ }^{45}$

Through a close study of just one of the city's many still-lifes, it becomes evident that these disparate urban fragments play an important civic role by harbouring the life of the citizens. What one sees in these urban fragments: the crowds of well-dressed Seventh-day Adventist worshippers leaving an old synagogue on a Saturday afternoon, the man getting his hair cut in the middle of a convenience store, the students having a full English breakfast in a Korean restaurant, and the old couple who have been coming to the same theatre for over sixty years, is Ottawa's unique civic life. These fragments are "human aquariums" whose diversity is a direct reflection of the variety of their uses and of the people who have inhabited them.

\footnotetext{
${ }^{45}$ Alain Miguelez, A Theatre Near You: 150 Years of Going to the Show in Ottawa-Gatineau (Canada: Penumbra Press, 2004), 281.
} 
Furthermore, they do not only support life but allow themselves to be shaped by it; these fragments display the history of the lives they have contained in their scars and additions. These urban fragments are, therefore, the true emblems of Ottawa's civic identity; they contain the potential to express the lives and values of Ottawa in their very real, physical presence.

By investigating the city from the perspective of the Ottawa Peasant, a new modern mythology is discovered. In this version of reality the city's identity is contained in various urban fragments that are arranged in discordant assemblages throughout the city. However, because these fragments are seen as "unremarkable" and have not been able to effectively communicate their civic lives, they are at risk of demolition, which would result in the loss of their important contributions to the city's identity. It is evident that in order to fully express the complexity of Ottawa's identity these fragments must be preserved and incorporated into new constructions. 


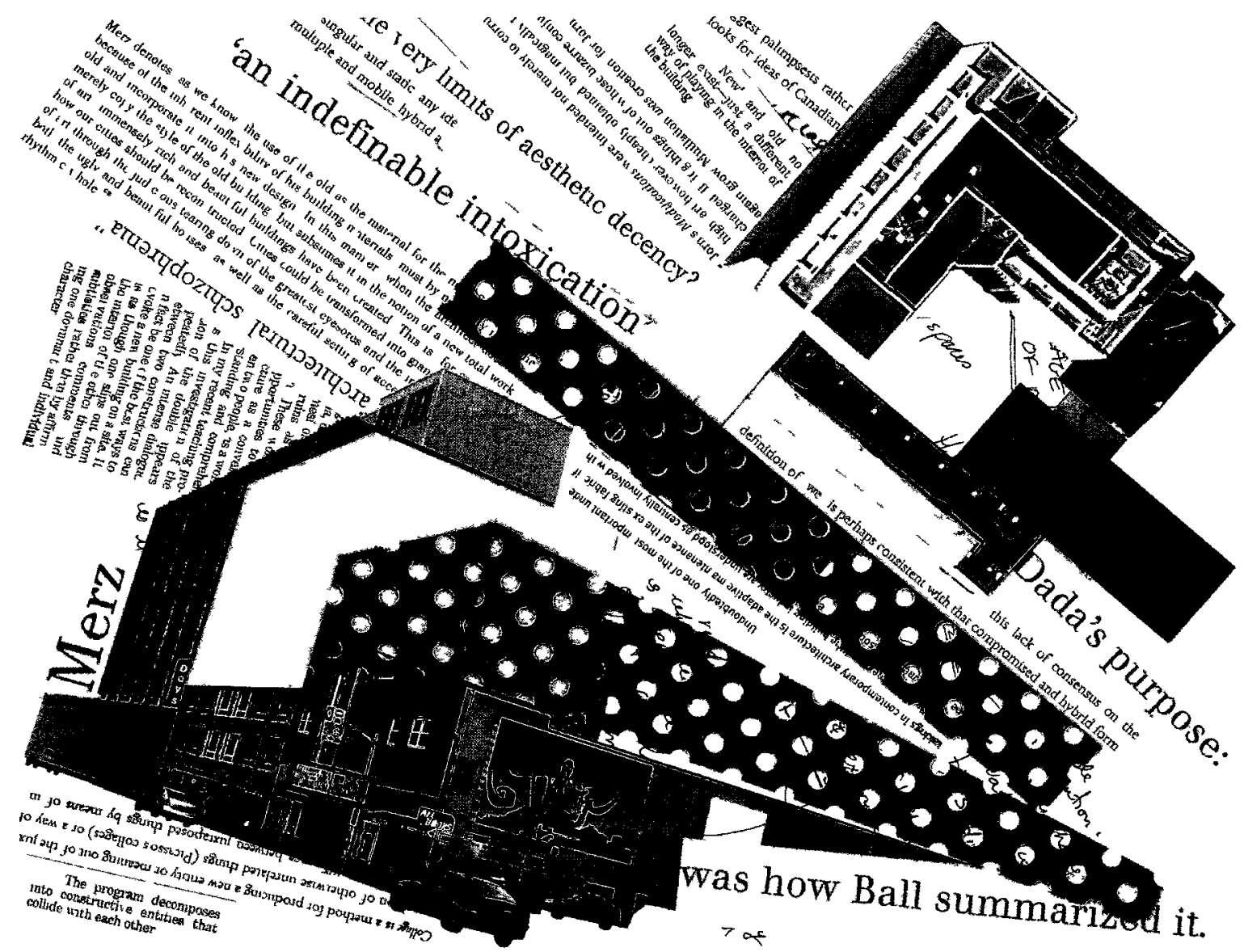

[Plate 4]

The Urban Collage 


\section{[Chapter 3]}

\section{Alchemy 101: Using Collage to Transform Worthless Urban Fragments}

Ottawa's surreal mythology, uncovered through the explorations of the Ottawa Peasant, demonstrates that the civic identity that must be expressed by the city's architecture is currently trapped within its unremarkable fabric. The very urban residue that the citizens perceive as a detriment to the expression of their identity is actually its guardian; the urban fragments are the supporters of the lives and values of the citizens. But because the fragments are modest and unable to communicate their hidden vitality they are often demolished, depreciating the city's identity. To prevent this depreciation, the fragments must be preserved and given value in the eyes of the citizens in a way that reflects their significant civic role.

One method for converting worthless materials into objects of great value was discovered through the experiments of Cubist collage. Colin Rowe and Fred Koetter demonstrate in Collage City that, not only is it possible to apply the principles of collage at an urban scale, it is imperative. "It is suggested that a collage approach, an approach in which objects are conscripted or seduced from out of their context, is - at the present day - the only way of dealing with the ultimate problems of, either or both, utopia and tradition." ${ }^{46}$ Collage City is Rowe and Koetter's response to the problems of "the city of modern architecture" that is "a congeries of conspicuously disparate objects" 47 and outlines their proposal for "what to do with it?"48 They propose a dialectic architecture that reconciles traditional and modern, figure and ground, specific and general, structure and event, certainty and ad hoc. In order to achieve

\footnotetext{
${ }^{46}$ Colin Rowe and Fred Koetter, Collage City (Massachusetts: MIT Press, 1978), 144.

${ }^{47}$ Rowe and Koetter, Collage City, 58.

${ }^{48}$ Rowe and Koetter, Collage City, 63.
} 
this dialectic of the future, architects must enter the territory of collage "a territory from which the architect and urbanist have, for the most part, excluded themselves," where "the blinding self-righteousness of unitary conviction is at last placed alongside a more tragic cognition of the dazzling and the scarcely to be resolved multiplicity of experience." 49

This thesis, however, requires more from the collage approach than a solution for "what to do with" the fragments of the modern city. Collage and its descendents, including Zurich and Berlin Dada, can provide further insight into how urban fragments can be transformed into valuable entities and celebrated as the emblems of Ottawa's civic life. Kurt Schwitters' Merz collages reveal additional mechanisms that can be used to unify the fragments, allowing them to represent the citizens' common identity and to project new meanings. Collage in its various forms, therefore, provides a model for how the city's disparate urban fragments can become the building blocks of its civic architecture.

The Cubist experiments that led to Georges Braque and Pablo Picasso's serendipitous discovery of the alchemical nature of collage are explained in Carsten-Peter Warncke's book Pablo Picasso: 1881-1973. Initially, the collaborating artists were challenging the limits of art as the imitation of nature by fluctuating between, "the twin poles of mimesis: on the one hand the ideal coincidence of object and representation, and on the other hand the complete absence of any representational value." ${ }^{50}$ This endeavour led to the development of Analytical Cubism, which involved the representation of the subject as a reordering of its dissected parts. In these works the elements of the image, such as colour and line, were freed from defining the subject and allowed to "obey the curious rules of the composition instead." ${ }^{51}$ Once these elements had been liberated from representation, Braque began to imbue them with their own expressive

\footnotetext{
${ }^{49}$ Rowe and Koetter, Collage City, 63.

${ }^{50}$ Carsten-Peter Warncke, Pablo Picasso: $1881-1973$ (Cologne: Taschen, 2003), 61.

${ }^{51}$ Warncke, Pablo Picasso, 72.
} 
potential by combining them to imitate material textures or by giving them their own physical materiality by mixing paint with sand and plaster. ${ }^{52}$

Braque's experiments with the materiality of painting reached a climax when he decided to substitute woodgrained wallpaper for his illusionist painting techniques, creating the first papier collé. In Collage: The Making of Modern Art, Brandon Taylor explains the significance this material substitution: "the drawing and the paper defined each other in a series of procedural and semantic orderings that would have massive implications for what was to follow." ${ }^{53}$ Picasso fully exploited the potential of Braque's invention ${ }^{54}$ by creating collage works, such as Still Life with Chair Caning, that combıned physical materials, illusionist surfaces, and Cubist painting. Warncke exposes the ramifications of collage by writing: “In collage - unlike papier collé - an object is introduced into a context in such a way as
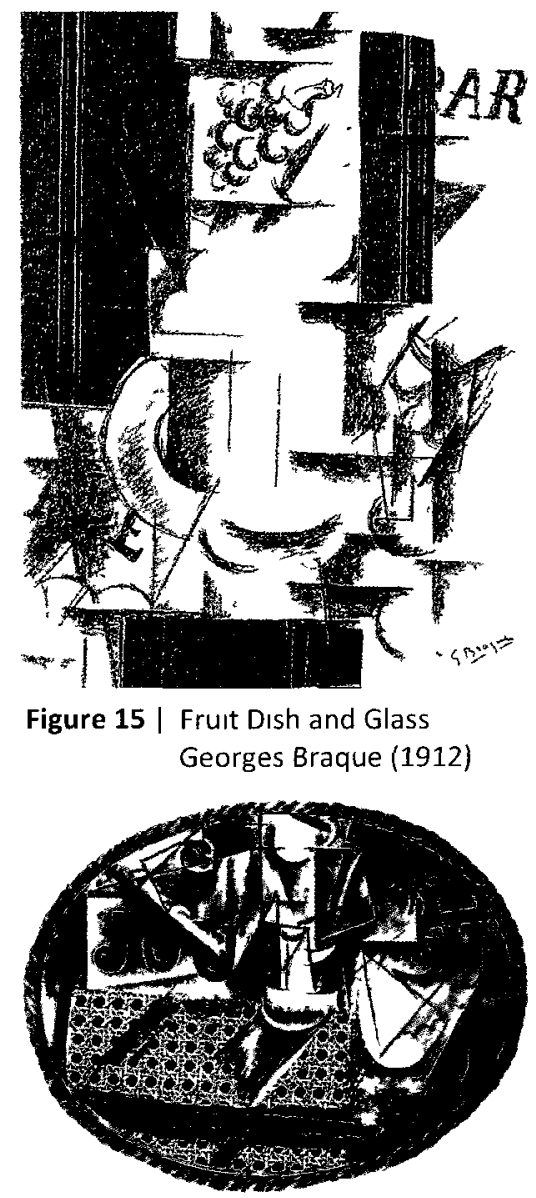

Figure 16 | Stıll Life with Chair Canıng Pablo Picasso (1912) to alter not only the medium but also the style and meaning of the motif." ${ }^{35}$

The great breakthrough of Cubist collage is the realization that the meaning of art need not be embedded deep within its figurative content but can instead rest lightly on its surface, in its physical materiality. Art is itself a sign. As Picasso's dealer, Daniel-Henry Kahnweiler explains: "The products of these arts are signs, emblems for the external world, not mirrors

\footnotetext{
${ }^{52}$ Warncke, Pablo Picasso, 83.

${ }^{53}$ Brandon Taylor, Collage: The Making of Modern Art (New York: Thames \& Hudson, 2004), 17.

${ }^{54}$ Taylor, Collage, 19.

${ }^{55}$ Warncke, Pablo Picasso, 86.
} 
reflecting the external world in a more or less distorting manner." ${ }^{56}$ Although the mission of Cubism was the liberation of the image, it also had the effect of elevating the value of the material. In collage, the material is the projector of meaning and therefore the steward of the artwork's value. Herein lies the alchemical formula of collage; humble materials are transformed into valuable signifiers by contributing their meanings to the overall sign of the artwork. Through collage, lead can not only equal but can exceed gold in value.

This alchemical formula can be equally applied to the humble materials that currently constitute the majority of Ottawa's urban fabric. Through the composition of the city's unremarkable fragments into a work of collage, the city's individual expressions of civic life are consolidated into a comprehensive representation of the city's identity. As a result of providing the citizens' with a physical manifestation of their common identity, the fragments gain immeasurable value. However, beyond simply recognizing the value of the urban fabric, it must also be celebrated so that it may engender a feeling of civic pride. The mechanisms for imbuing collage with emotive capacities were developed by the descendents of Cubism.

The movements that followed Cubist collage furthered its original investigations by continuing to push the boundaries of representation and meaning. According to Louis Aragon, artists had no choice but to continue the work of cubism because, "The principle of collage once admitted, painters had unknowingly passed from white to black magic. It was too late to retreat." 57 One of these descendents is Zurich Dada, which Taylor describes as a reaction against "the political madness of the First World War." ${ }^{58}$ In response to the war, the Dadaists abandoned all meaning; this is demonstrated in the works of Hans Arp who wrote, "we rejected

\footnotetext{
${ }^{56}$ Kahnweiler quoted in Taylor, Collage, 28.

${ }^{57}$ Aragon quoted in Taylor, Collage, 71.

${ }^{58}$ Taylor, Collage, 37.
} 
all mimesis and description, giving free reign to the Elementary and Spontaneous." ${ }^{59}$ Taylor explains how all products of Zurich Dada were vigorously combined in Hugo Ball's Cabaret Voltaire:

Dada's liking for sensory overload - the remorseless piling up of sensations without reference to the distinctions between writing, painting, music, theatre and dance as separate arts. The collision of these forms in a chaotic interplay of free and raucous expression was entirely to Dada's purpose: 'an indefinable intoxication' was how Ball summarized it. ${ }^{60}$

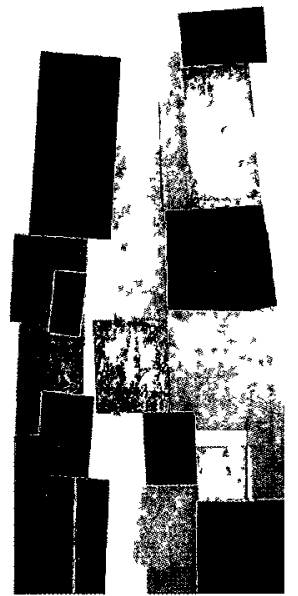

Figure 17 | Squares According to the Laws of Chance Hans Arp (1917)

By demonstrating the ability of collision and overload to generate a feeling of Intoxication, the Cabaret Voltaire reveals that while Dadaists relinquished the creation of meaning they still worked to arouse emotion. The emotive potential of Zurich Dada suggests that it might also be possible to use the language of collage to generate the feeling of celebration that is required to elevate the status of Ottawa's urban fabric. Through the excessive contrast and juxtaposition of old and new buildings, forms, and materials this emotional intoxication can be heightened to an urban scale. At this magnitude the feelıng of jubilation has the potential to inspire the citizens to take pride in their cityscape. However, they must also be encouraged to recognize that the cause of this celebration is their own civic identity.

In Berlin, Dadaists intentionally manipulated the meanings of the materials in their collages to inspire social awareness. The founder of Berlin Dada, Richard Huelsenbeck described his new Dadaist vision in his first lecture as, "a single step away from politics." ${ }^{\text {11 }}$ Berlin Dadaists opposed the Zurich artists' rejection of literal meaning and chose instead to use collage

\footnotetext{
${ }^{59}$ Arp quoted in Taylor, Collage, 39.

${ }^{60}$ Taylor, Collage, 38.

${ }^{61}$ Huelsenbeck quoted in Taylor, Collage, 40.
} 
elements such as photo-fragments that were "daringly referential" examples of "dangerous political metaphorization." ${ }^{62}$ As Raoul Hausmann explains, in his Synthetic Cino of Painting pamphlet of 1918, other collage materials were also used to generate political metaphor: "In Dada you will recognise your own true condition... Wonderful constellations in real materials, wire, glass, cardboard, textiles are the organic equivalents of your own complete brittleness, your own shoddiness." ${ }^{63}$ By using

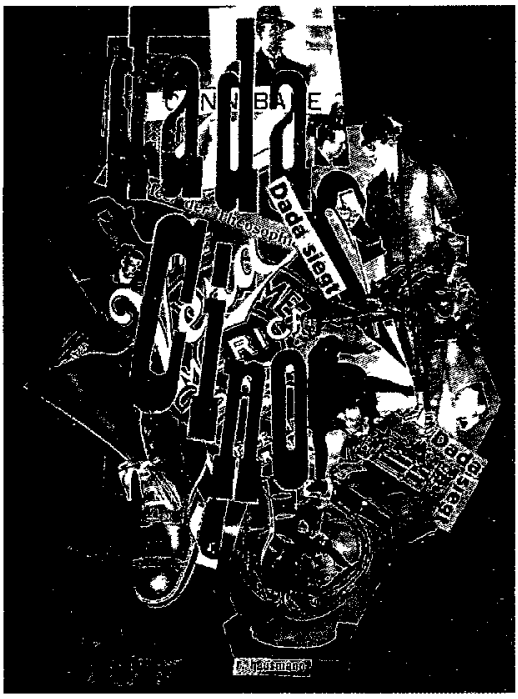

Figure 18 | Dada Cino Raoul Hausmann (1920) commonplace materials, Hausmann forces the viewer to intellectually engage with materials that are usually taken for granted. Once the viewer realizes this fact, their familiarity and intimate tactile knowledge of these "real" materials causes the analysis to be reflected back towards the viewer's own self.

The accessible and ephemeral qualities of everyday materials, which Hausmann used to reveal the "true condition" of the individual, can also be found in Ottawa's everyday urban fabric. Therefore, when used in an architectural collage, these qualities should be equally capable of exposing the "true condition" of the city. Their familiarity with the commonplace urban fabric should cause the citizens to question its inclusion in new architecture, which will help the citizens' to realize that the new architectural entity is actually a reflection of their own lives. Through the mechanisms of collage the citizens' lives find their representation in commonplace buildings, which are composed into an expression of celebration and assigned a great value for their ability to convey the city's identity. This identity, however, is more than just the sum of its parts; it symbolizes the unity of the citizens and their common values. As

\footnotetext{
62 Taylor, Collage, 43.

63 Hausmann quoted in Taylor, Collage, 40.
} 
such, the architectural collage must also display a level of synthesis that allows for the citizens to read it as a unified expression.

Kurt Schwitters' collage revolution was the result of his use of synthesis and metamorphosis to transform materials and create collages that not only expressed the sum of the meanings inherent in their materials but projected completely new signs. Schwitters distinguished his work by giving it the name Merz, a term derived from a fragment of the word Kommerz that appeared in one of his collages. ${ }^{64}$ His compulsion to build something new was the product of the political upheavals of Germany in 1918 that

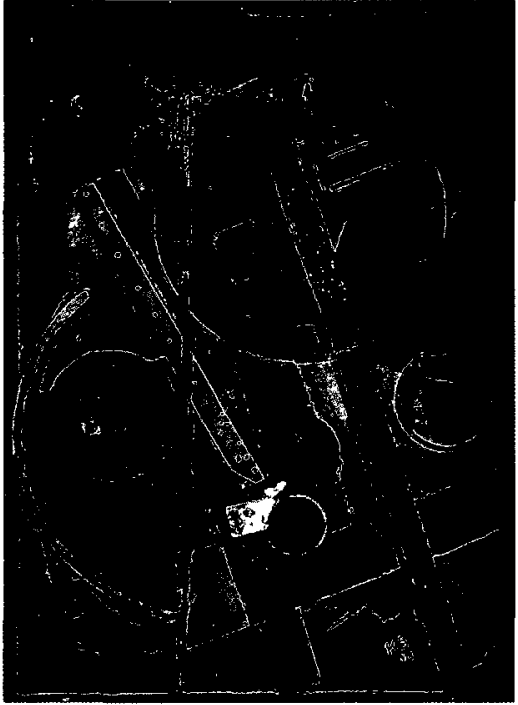

Figure 19 | The Worker Picture Kurt Schwitters (1919)

culminated in the outbreak of the November Revolution and inspired him to realize that, "Everything had broken down in any case and new things had to be made out of the fragments." 65

Schwitters' fragments were the products of what Taylor describes as his, "joyous descent into the material residuum of the gutter and the dustbin." ${ }^{66}$ He would wander the streets of Hanover collecting scraps of wood, metal, wire, cloth and mechanical parts: "real" materials selected for the same qualities that caught the attention of his Dadaist counterparts. However, unlike the Dadaists, Schwitters saw beyond their inherent meanings to the signs the materials could achieve through metamorphosis. Schwitters explained that he transformed materials through, "dividing, deforming, overlapping, or painting over," and, regardless of their original functions, he saw new artistic potential in each fragment:

\footnotetext{
${ }^{64}$ Taylor, Collage, 45.

${ }^{65}$ Schwitters quoted in Taylor, Collage, 44.

${ }^{66}$ Taylor, Collage, 45.
} 
In Merzmalerei [Merzpainting] the box top, playing card and newspaper clipping become surfaces; string, brushstroke and pencil stroke become line; wire-netting becomes overpainting, pasted-on greaseproof paper becomes varnish, cotton becomes softness... ${ }^{67}$

In The Collages of Kurt Schwitters: Tradition and Innovation, Dorothea Dietrich describes the different forms of Schwitters' Merz. In Merzbau (Merzbuilding) Schwitters increased the scale and complexity of Merz by completely transforming his studio and adjacent rooms, "into an allencompassing, ever-expanding collage environment." ${ }^{\prime 68}$ Dietrich explains that the main goal of Merzbau was to create a synthesis from the fragments, which "were not simply conceived as polar opposites, but together, as building stones for a new, greater whole." ${ }^{69}$ Schwitters intended his Merzbau to function as a "blueprint for a new kind of

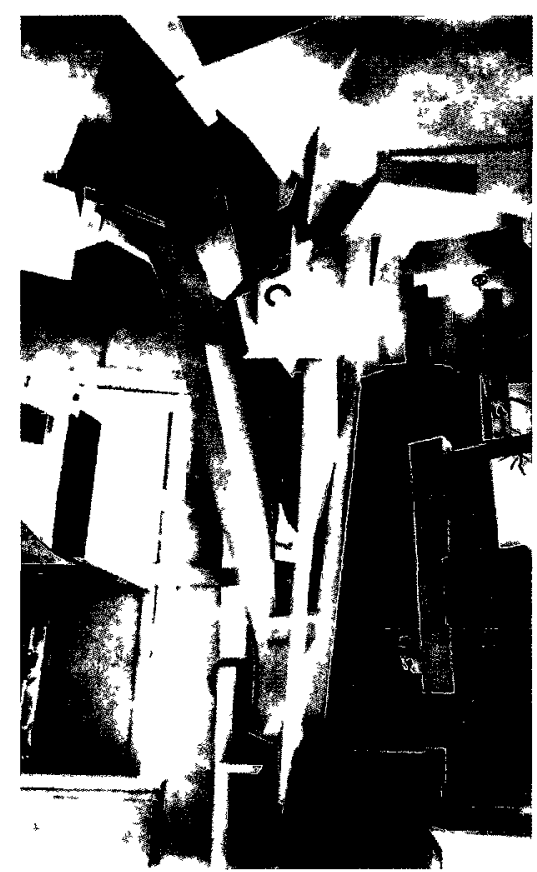

Figure 20 | Merzbau Kurt Schwitters (c. 1930) architecture;" ${ }^{70}$ he wrote:

"Merz denotes, as we know, the use of the old as the material for the new... This is, for example, how our cities should be reconstructed. Cities could be transformed into giant Merz works of art through the judicious tearing down of the greatest eyesores and the incorporation of both the ugly and beautiful houses, as well as the careful setting of accents, in a larger rhythmic whole." ${ }^{71}$

Schwitters' process of transforming the various materials into a new unified entity is the final step in the creation of a new architectural expression of Ottawa's identity. By dividing and deforming the urban fragments, giving them new functions, and synthesizing them through

\footnotetext{
${ }^{67}$ Schwitters quoted in Taylor, Collage, 46.

68 Dorothea Dietrich, The Collages of Kurt Schwitters: Tradition and Innovation (New York: Cambridge University Press, 1993), 164.

${ }^{69}$ Dietrich, The Collages of Kurt Schwitters, 198.

${ }^{70}$ Dietrich, The Collages of Kurt Schwitters, 200.

${ }^{71}$ Schwitters quoted in Dietrich, The Collages of Kurt Schwitters, 200.
} 
overlapping and overpainting an original form of architectural expression can be created. This process follows Schwitters' architectural blueprint in principle, but it must be further adapted to satisfy the specific needs of Ottawa's search for civic representation. The collage model - of giving the urban fragments valuable meaning to preserve them, celebrating their ability to reflect the citizens' life, and synthesizing them to create a new vision - must be tested in a real urban situation to determine if it is truly capable of generating civic architecture.

The Ottawa Public Library Board has specifically stated that the new Ottawa Central Library should provide a "distinguished city landmark, a symbolic presence and a sense of civic identity. ${ }^{\prime 72}$ Because of these demands and because the Ottawa Central Library must represent the lives and values of all citizens, this project presents the ideal opportunity to test the ability of the collage model to transform the city's urban fragments into the emblems of its unique identity. If it succeeds, the Ottawa Central Library would provide the city with a convincing precedent for the preservation of the city's unremarkable fragments, which are currently being thoughtlessly demolished. The building would demonstrate that standard development practices such as these are actually the cause of the city's current lack of architectural representation.

\footnotetext{
${ }^{72}$ Ottawa Public Library, New Central Library, 3.
} 


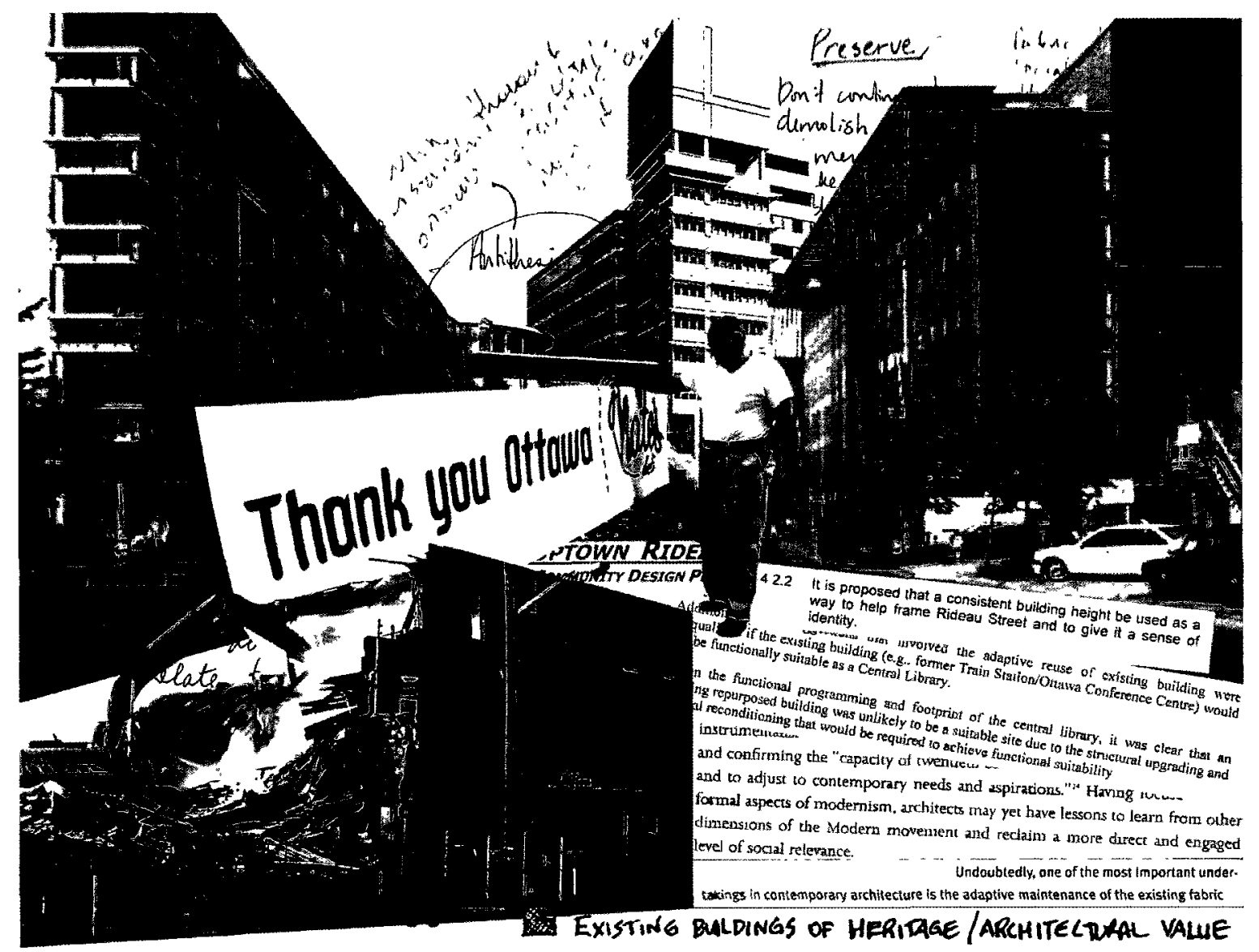

[Plate 5]

The Antithesis 


\section{[Chapter 4]}

\section{Ottawa's Urban Design Guidelines for Suppressing Civic Identity}

The previous three chapters of this thesis outline a process for revealing Ottawa's architectural identity, currently hidden within the city's urban fabric. I have argued that the city's architects should preserve the urban fragments that harbour the life of Ottawa's citizens, celebrate them by elevating their status through collage, and draw from them the inspiration to create a new vision for the future. However, these suggestions present a stark contrast when compared to Ottawa's current development practices. The argument for preserving materially valueless urban fragments opposes the usual tendency to thoughtlessly demolish all unremarkable buildings on site. It also challenges the practice of avoiding sites with existing buildings and disregarding the opportunity to transform the city's existing fabric into something remarkable. The conviction that the city's identity is the product of the lives of its citizens discredits the common practice of looking elsewhere to find alien forms of civic identity to be, no doubt unsuccessfully, imitated. These contradictions expose the fact that current urban development practices are actively suppressing any potential for representing the city's identity through its architecture.

The search for the civic identity of Ottawa is an exercise in futility because the city is in a state of perpetual demolition. Ottawa's developers and their architects have neglected to acknowledge that the city's fragile urban fragments harbour this identity and, as a result, continue to demolish them. One blatant example of this form of civic negligence is the total 
destruction of the "landmark" "Nate's Deli, which used to be located directly across Rideau Street from the project site. This deli was one of the few independent Jewish delis in Ottawa. It remained open for exactly fifty years at 316 Rideau Street and was "famous among locals and Parliamentarians alike." ${ }^{74}$ Nate's was completely destroyed along with: the rental space for the African Heritage Languages and Cultural Centre; The Place Next Door, which was a restaurant and catering company associated with

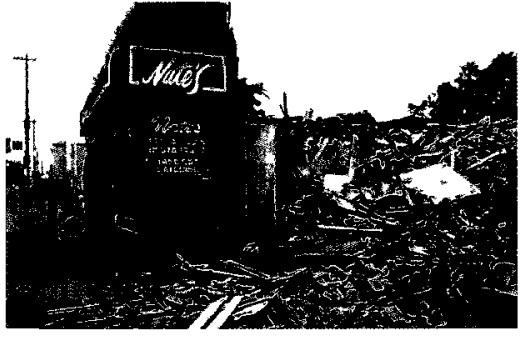

Figure 21 | Nate's Delı (August 26, 2010)

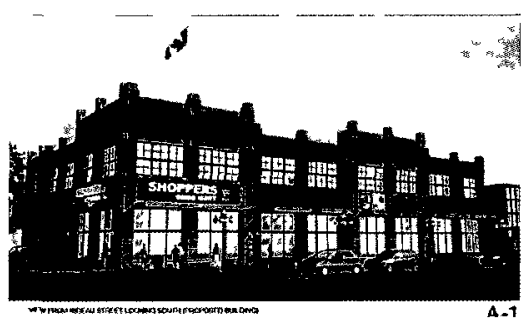

Figure 22 | New Shoppers Drug Mart Nate's; and three private homes along Besserer Street. These buildings will soon be replaced by a mixed-use development comprised of a large Shoppers Drug Mart franchise with its storage and loading facilities, a medical clinic, three apartments, and an over-sized parking lot that will accommodate forty-two cars. By demolishing this human aquarium, the civic life that it contained has been extinguished.

Although the building that housed Nate's Deli was irrefutably unremarkable, it was still distinguished by the local community, as represented by the Rideau Street Redevelopment Working Group (RSRWG), as one of the "Buildings of Heritage/Architectural Value."75 The RSRWG was made up of representatives from the Rideau Street businesses, from the adjacent neighbourhoods of Sandy Hill and Lower Town East, and from the City of Ottawa who collaborated to put forward the Uptown Rideau: Community Design Plan, which is "a road map

\footnotetext{
73 "Wreckers send remains of Nate's Deli into Ottawa's dusty memory," Ottawa Citizen, August 26, 2010, accessed February 13, 2011, http://www.ottawacitizen.com/life/Wreckers+send+remains+Nate+Deli+ into+Ottawa+dusty+memory/3442783/story.html

74 "A Lesson for Europe from Nate's Deli," National Post, May 29, 2010, accessed February 13, 2011, http://fullcomment.nationalpost.com/2010/05/29/a-lesson-for-europe-from-nates-deli/

${ }^{75}$ City of Ottawa, Uptown Rideau: Community Design Plan, Rideau Street Redevelopment Working Group (Ottawa: City of Ottawa, 2005), 9.
} 
to the successful and respectful transformation of this area into an image of pride for everyone."76 In Uptown Rideau the RSRWG valued the building for containing a "landmark business" ${ }^{177}$ and planned to add the building to the city's Heritage Reference List. ${ }^{78}$

By the simple act of showing preference to a structure with no obvious architectural value, the citizens demonstrated their civic values. They reveal their attachment to independent and unique establishments where all are welcome and their will to sustain the inspirational story of the owner, David Smith, the son of Russian-Jewish immigrant parents who not only succeeded with his small business in Ottawa but rose to become an exemplary member of society. ${ }^{79}$ They demonstrate that this urban fragment had the ability to represent not only their civic life, but also their common values and identity. By wanting to preserve this structure, the citizens recognize its capacity to influence the identity of future generations; however, the thoughtless act of demolishing Nate's Deli has ensured that this potential shall never be realized.

Since demolition is the most common method for dealing with the unremarkable urban fabric of Ottawa, those who want to circumvent its associated costs often choose to avoid sites that contain urban fragments altogether. This preference for empty lots shows that developers have little interest in celebrating the city's important human aquariums. One such developer is the Ottawa Public Library Board who, in its various reports between 2009 and 2010, provided several excuses for their avoidance of "site encumbrances such as... buildings that require

\footnotetext{
${ }^{76}$ City of Ottawa, Uptown Rideau, 1.

${ }^{77}$ City of Ottawa, Uptown Rideau, 9.

${ }^{78}$ City of Ottawa, Uptown Rideau, 16.

${ }^{79}$ Smith is a dedicated philanthropist who founded the David Smith Youth Centre (a drug treatment and rehabilitation centre for Ottawa teens) that has expanded to campuses in Carleton Place and Carp, as well as the Ottawa Technical Learning Centre. He participated in numerous other local and international charitable organizations and, among various other awards, received an Honorary Doctorate from the University of Ottawa in 2001 and the Order of Ontario in 2006.
} 
demolition, or buildings that must remain on the site." 80 There were several site suggestions that proposed the adaptive reuse of important civic buildings such as Union Station and the Ottawa Congress Centre, but the board disqualified them for not being functionally suitable. The board also determined that it was unlikely that any existing buildings would be appropriate for reuse, "due to the structural upgrading and general reconditioning that would be required to achieve functional suitability." ${ }^{81}$ By only focussing on the "encumbrances" of reusing existing buildings, which are common to every reuse project and not insurmountable, the library board has failed to see the incredible potential for civic expression that lays dormant in the city's existing fabric.

Based on this oversight, the Ottawa Public Library Board has come to the misinformed conclusion that the city of Ottawa is, "singularly lacking in a symbol of city life." ${ }^{82}$ However, Ottawa's problem lies not in the city's lack of vital signs but in the inability of developers and architects to recognize and revive those that already exist in a way that effectively conveys the importance of their civic contributions. By declining to engage with existing buildings, the library board is forfeiting the opportunity to lead the way towards elevating the city's fabric to its rightful place, as the expression of Ottawa's identity. Instead, the board is naively hoping to create Ottawa's missing symbol of city life by replicating the success of "so many cities around the world" that have "been building new public libraries," which "have also become symbols of civic pride" simply because they are "Architecturally inspiring." 83

\footnotetext{
${ }^{80}$ Ottawa Public Library, New Central Library, Appendix B1.

${ }^{81}$ City of Ottawa. Corporate Services and Economic Development Committee, Report 44 (Ottawa: City of Ottawa, 2009), 92.

${ }^{82}$ Ottawa Public Library Board, New Central Library, 8.

${ }^{83}$ Ottawa Public Library Board, New Central Library, 5.
} 
This eagerness to replicate the architectural forms of other cities presents yet another hurdle in the way of the citizens' quest to discover Ottawa's unique identity. Even the RSRWG's Uptown Rideau: Community Design Plan, which had so astutely argued for the preservation of unremarkable

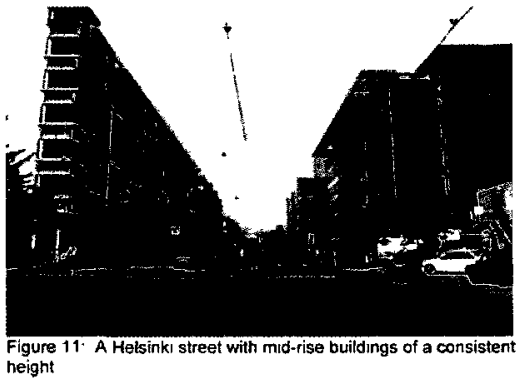

Figure 23 | Helsinki's Consistent Urban Massing - Uptown Rideau urban fragments such as Nate's Deli, failed to recognize their potential as emblems of the city's identity. Instead, the RSRWG looked to imitate the urban form of European cities as a means with which to create identity. The plan proposes that the buildings along Rideau Street should have a more consistent height, following the models of Helsinki and Paris that have "a more disciplined and more homogeneous style of development." 84 The justification for this urban makeover is that the new consistency will, "help frame Rideau Street and to give it a sense of identity. ${ }^{85}$ Somehow the urban form of Helsinki and Paris has become synonymous with civic identity and is considered to be a universal cure for urban identities in crisis.

This questionable remedy is not only ineffective; it also inflicts further damage by causing the city of Ottawa to turn against its true identity for its failure to conform to the "ideal" urban form. Although Rideau Street contains numerous capsules of civic life whose diversity reflects that of their purpose and inhabitation, the RSRWG sees their resulting formal inconsistency as a shortcoming which is to blame for the city's lack of identity: "This form of urbanization can best be described as a scattered collection of individual buildings and has left the Uptown Rideau area in search of an identity" ${ }^{86}$ This failure of the citizens to recognize their own civic reflection when standing directly in front of it, demonstrates the extent of the damage

\footnotetext{
${ }^{84}$ City of Ottawa, Uptown Rideau, 12.

${ }^{85}$ City of Ottawa, Uptown Rideau, 12.

${ }^{86}$ City of Ottawa, Uptown Rideau, 4.
} 
caused by searching for Ottawa's identity in other cities. It also exposes the urgency with which the city's inconsistent urban identifiers must be celebrated and empowered to reveal their civic importance.

By affirming architecture's social responsibility to the citizens and suggesting that the expression of Ottawa's unique identity should inspire a new architectural language, the project also opposes the tenets of the country's dominant architectural style: Mannerist Modernism. In Marco Polo's essay Mannered Modernism: Fifteen Years of Canadian Architecture, he explains that Modern architecture re-emerged in Canada as a source of formal expression in the

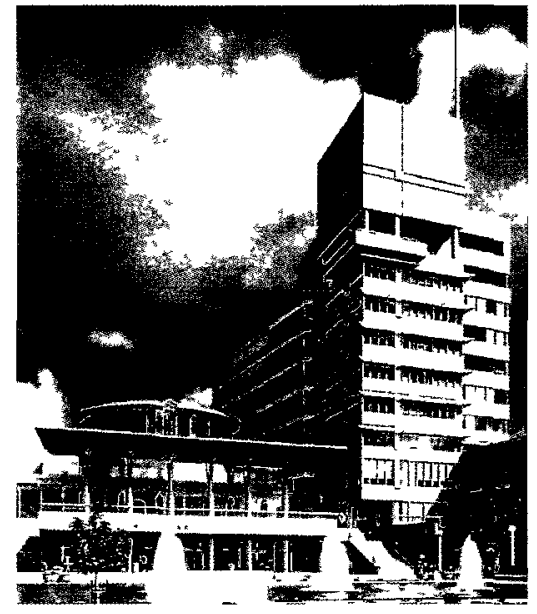

Figure 24 | Kitchener City Hall - KPMB late 1980 s as a reaction against a brief period of postmodern historicism. This renewed Modernism turned architecture's attention towards "concerns unexplored in late Modern works: history, urbanity, spatial and material complexity. ${ }^{87}$ However, it also displayed eclectic revivalist tendencies in projects, such as the final entries for the 1989 Kitchener City Hall competition, where architects were influenced by numerous sources from Modernist history and ironically used "modernism, founded on the rejection of the historicism of the nineteenth century, as a mannered historic style." ${ }^{18}$

In this later iteration, Modern architecture lost its previously important social agenda. Polo explains: "The Modern aesthetic is decontextualized from the socio-political and economic conditions from which it originally emerged, and recontextualized... in a milieu where it is valued not as an agent of cultural change, not as a means to an end, but as an end in itself." ${ }^{\prime 9}$ In

\footnotetext{
${ }^{87}$ Polo, "Mannered Modernism," 214.

${ }^{88}$ Polo, "Mannered Modernism," 222.

89 Polo, "Mannered Modernism," 217-218.
} 
effect it has become another form of art pour l'art which retreats from "the social dimension of modernism" to indulge its new "fascination with 'surface, image and play.",90 This aesthetic approach to architecture, which involves arranging various Modernist elements into a new composition, is evident in Ottawa's most recent civic

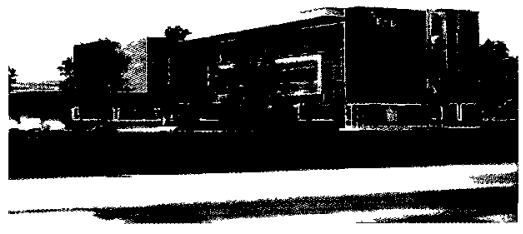

Figure 25 | Ottawa Central Archives Ottawa Public Library Materials Centre

buildings, including the new City of Ottawa Central Archives that was designed by Shoalts and Zaback Architects and built in joint venture with Barry J. Hobin and Associates Architects. Instead of conforming to this dominant superficial style, the design for the new Ottawa Central Library should instead heed Polo's concluding suggestion that, "architects may yet have lessons to learn from other dimensions of the Modern movement and reclaim a more direct and engaged level of social relevance." ${ }^{91}$

Beyond the accusation that the city's current architecture displays superficial mannerist tendencies, it has also been blamed for the city's lack of architectural identity. Andrew Grufts condemns this form of architecture in his introduction to Substance Over Spectacle: Contemporary Canadian Architecture: "The resultant work ends up exuding an anonymity that somehow drains its character and 'authenticity,' leaving some sort of architectural simulacrum a generic architecture indistinguishable from any other, to which no one can relate." ${ }^{92}$ The Ottawa Central Library project must instead counter these effects by generating purposeful architecture that creates a new language that is specific to the city, is inspired by the desire to express its current identity, and projects a bold vision for its future. The project must create a "Spectacle of Substance" that exudes a particularity that enriches its character and

\footnotetext{
${ }^{90}$ Mary McLeod quoted in Polo, "Mannered Modernism," 218.

91 Polo, "Mannered Modernism," 223.

${ }^{92}$ Andrew Gruft, introduction to Substance over Spectacle: Contemporary Canadian Architecture, edited by Andrew Gruft (Vancouver: Arsenal Pulp Press, 2005), 8.
} 
"authenticity" resulting in an architectural innovation - a unique architecture distinguishable from all others, to which all citizens can relate. 


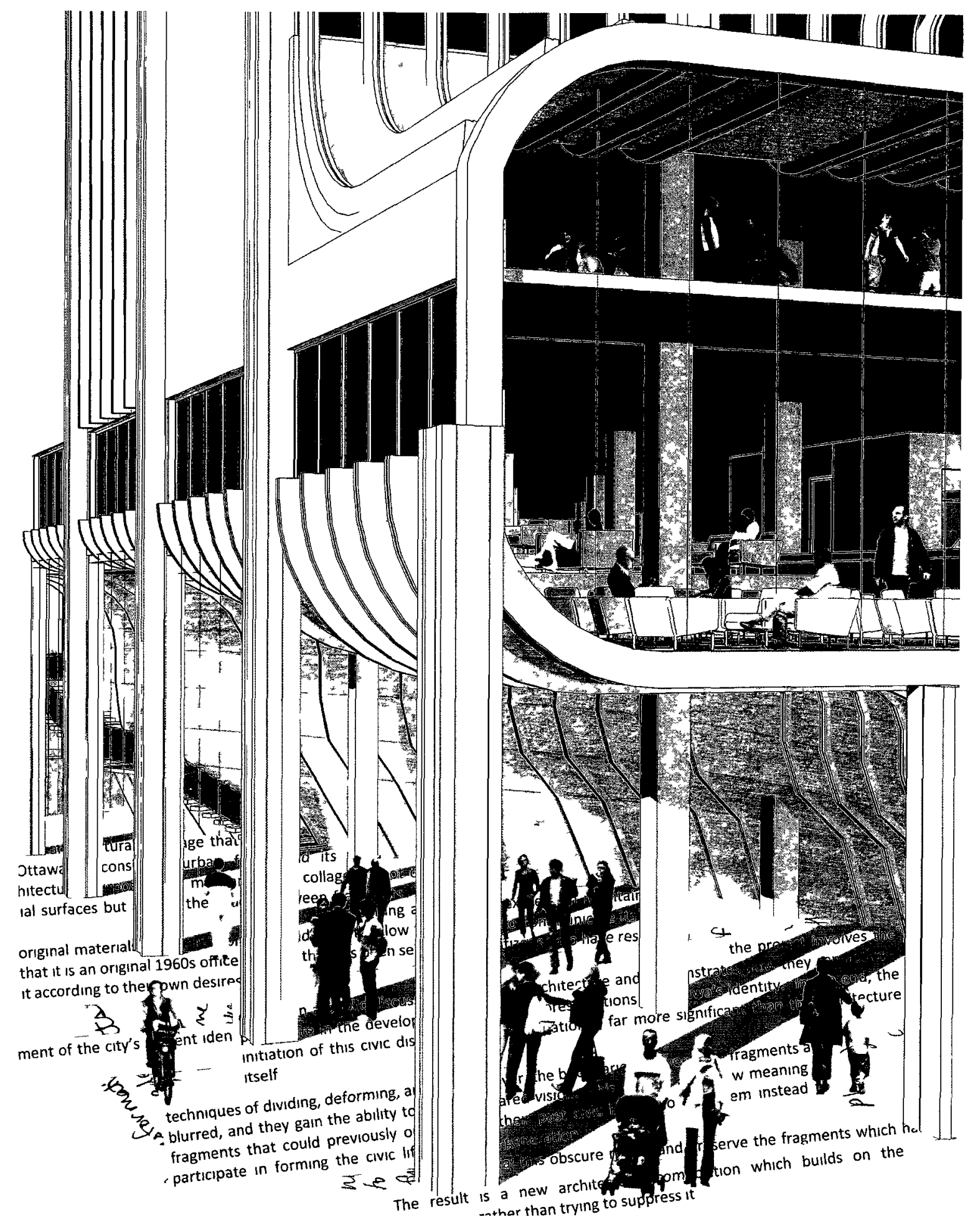

[Plate 6]

The Project 


\section{[Chapter 5]}

\section{A Proposal for the New Ottawa Central Library}

The "stamp of originality" and architectural innovation of the Ottawa Central Library project, which are necessary for differentiating Ottawa's civic identity, must be inspired by the contemporary reality of the city. Since Ottawa's reality is currently hidden from view and trapped within the city's unremarkable urban fragments, the project's architecture must endeavour to reveal this obscure reality and preserve the fragments which harbour it. To this effect, the project will employ the alchemical formula of collage. It will compose important urban fragments and new entities into a work of collage that values the fragments for their inherent meanings and civic life. It will celebrate and elevate them using the collage mechanisms of juxtaposition and excess. It will synthesize the new fragments with the old through a process of metamorphosis. The project will test the proposed collage model and its ability to create civic architecture - the embodiment of the city's present identity and the new vision for its future.

The functional program for the Ottawa Central Library is derived from the Resource Planning Group's (RPG) New Central Library: Functional Building Program that was prepared for the Ottawa Public Library Board. All program elements from this document have been accommodated in the design of the project. This strict adherence to the program is meant to demonstrate that, contrary to the opinions expressed in the Corporate Services and Economic Development Committee report, existing buildings do have the potential to: "be functionally suitable as a Central Library." ${ }^{193}$ Furthermore, beyond mere suitability, this project demonstrates

\footnotetext{
${ }^{93}$ Corporate Services and Economic Development Committee, Report 44, 92.
} 
that the use of existing buildings can also inspire innovative arrangements and interrelationships of the different library functions. Although RPG included component functional diagrams in the Functional Building Program to demonstrate how components should be spatially organized and interrelated, this Ottawa Central Library project proposes a different composition that is inspired by the existing urban fragments and their connections to the site and the community. In effect, these functional diagrams have been disassembled into fragments that are then either merged with existing buildings or added on to the composition as distinct architectural entities.

The project preserves four of the city's unremarkable urban fragments and, more importantly, the civic life they have contained. It appreciates the diversity of the buildings that were originally the Adath Jeshurun Synagogue, Constitution Building, Town House Motor Hotel, and Nelson Theatre, which allows them to express their different uses and the lives they have contained. It draws on the unique characteristics of the fragments when assigning to them new program elements, which either coincide with the existing form or contradict it in a way that requires alterations to improve not only functionality but also the composition as a whole. Any additional program elements are designed following the logic of the original urban fabric; their massing and materiality reflect their unique inner lives, giving each new fragment its own individual quality. The result is a new architectural composition which builds on the heterogeneity of the urban fabric rather than trying to suppress it.

The new programmatic elements engage with the existing urban fragments in a way that builds on the past civic lives that they have contained and that they express through their physical forms. The life of the former synagogue and its later incarnation as a Seventh-day Adventist church inspired the use of the building as the library's Heritage Gateway, which allows this fragment to continue telling the history of Ottawa as it has been influenced by different generations of immigrant communities. It will provide temporary exhibit, event, and lecture 


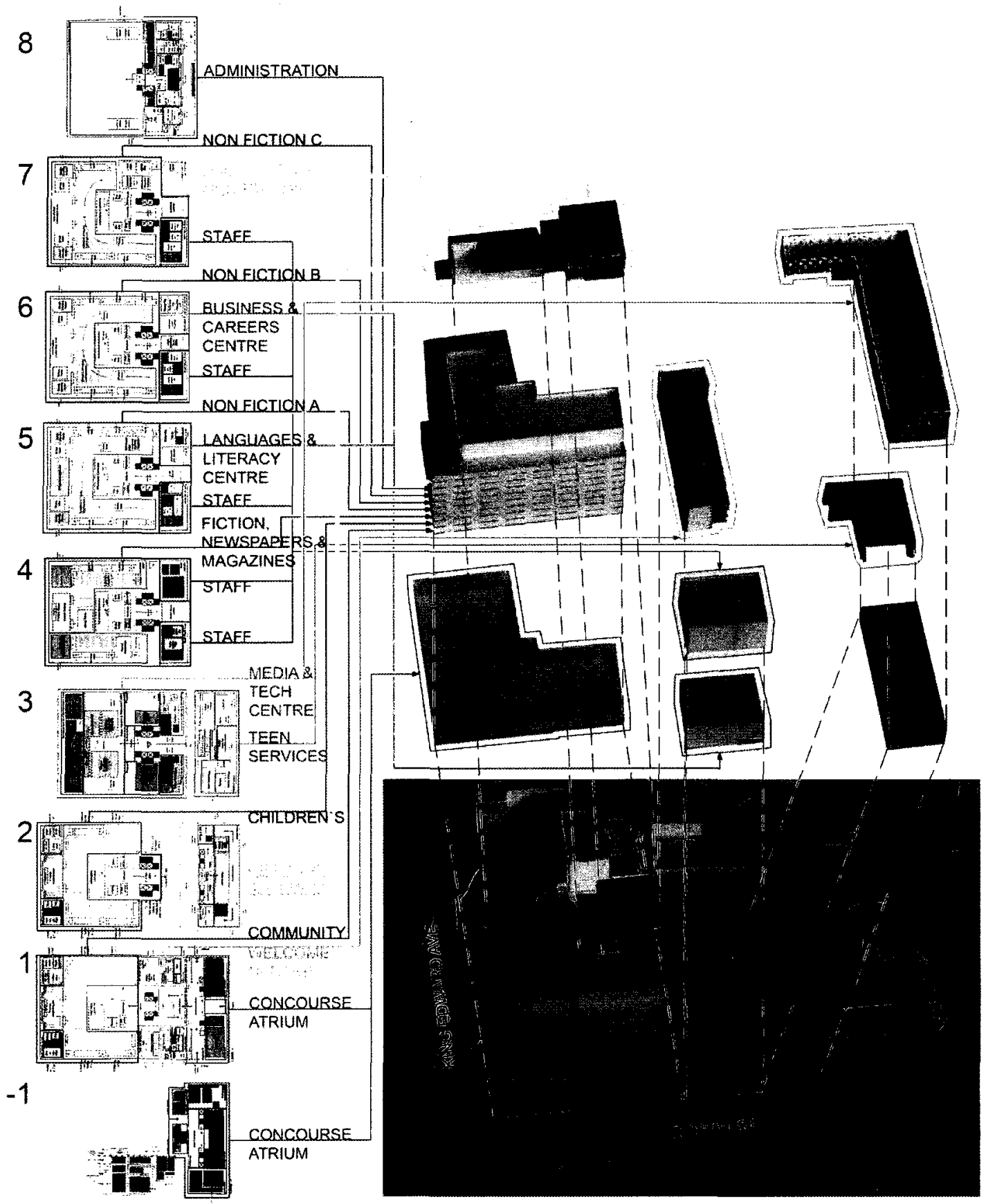

Ottawa Public Library: New Central Library - Functional Building Program Confidential Final Draft (March 2009 - Resource Planning Group Inc.)

\section{[Plate 7]}

Preserving the Urban Fabric 
spaces for showcasing city developments that deal with heritage issues, which can also be used by the community for receptions and recitals. ${ }^{94}$

The private and reclusive life of the Constitution Building is symbolically subverted by its new functions, which assimilate the building into the vibrant civic life of the street and take advantage of the building's prominent corner location. The first two levels are used for the Concourse Atrium that provides public gathering spaces, including an auditorium with performance space, meeting rooms, and the library café as well as retail spaces. ${ }^{95}$ The third to eighth levels accommodate the traditional library areas, including the Community Library, Children's Services, Fiction/Newspapers and Magazines, and the Non Fiction collections $A$, B, and $C$ that contain all reference materials in the Dewy system from 000 to $999 .^{96}$ The Community Library is closest to and most visible from the street and uses the exterior area created by the setback of the upper stories as an exterior amenity space. All other library floors make use of the Constitution Building's generous L-shaped floor plates, which provide ample space for the collections and excellent daylighting for the reading areas. The ninth floor is partially used for the library's Administration spaces, which take advantage of the sweeping views from this level by using them to create a stunning backdrop for the important Civic Suite, which is comprised of the boardroom and offices for senior library personnel. ${ }^{97}$ The remaining portion of the ninth floor, as well as the tenth and eleventh floors, is used as Leasable Space that can also accommodate any future expansion of the library. ${ }^{98}$

The odd, transient life of a 1960s motor hotel, which has persisted in a downtown location, is preserved in the memory of its telltale auto-centric form; however, this form has

\footnotetext{
${ }^{94}$ Ottawa Public Library, New Central Library, A.2.

${ }^{95}$ Ottawa Public Library, New Central Library, A.1.

${ }^{96}$ Ottawa Public Library, New Central Library, B.2 - B.3, B.5, B.7-B.9.

${ }^{97}$ Ottawa Public Library, New Central Library, C.1.

${ }^{98}$ Ottawa Public Library, New Central Library, D.1.
} 
been repurposed to provide generous pedestrian-centric outdoor amenity spaces instead. New programs have been inserted into the building's shell, which provide vital civic amenities for the community. The Business and Careers Centre is located on the ground floor fronting on Rideau Street so that it may provide a welcoming and easily accessible environment for local citizens who are either looking for work, networking possibilities, or assistance with starting a new business. $^{99}$ The Languages and Literacy Centre is located on the second floor, but it uses the same accessible entry point to invite new immigrants and those seeking to improve their literacy. ${ }^{100}$ The Welcome Centre is housed in the main body of the motel, which is at the centre of the site. This location allows for all street-fronting programs to be completely autonomous from the library; they are fully accessible to the public, with no need for security gates, and can remain open beyond the working hours of the library. The Welcome Centre therefore provides the secure entry point to the traditional library spaces and all of their precious literary holdings. ${ }^{101}$

The unique civic life of the Bytowne, one of the last independent movie houses in the city and the only one to feature independent and foreign films, will be preserved in its entirety and will act as an additional amenity space to the library program. It will continue with its usual line-up and its participation in festivals but will provide an additional auditorium space for the library during the day or for special events. This will ensure that the Bytowne maintains its important civic role and continues to shape the civic identity of future generations.

The fragments of additional program elements were designed and located according to the specific needs of the civic life they will harbour. The permanent exhibition spaces for the Heritage Gateway have been combined with the collections, reading and staff areas for the

\footnotetext{
${ }^{99}$ Ottawa Public Library, New Central Library, B.8.

${ }^{100}$ Ottawa Public Library, New Central Library, B.7.

${ }^{101}$ Ottawa Public Library, New Central Library, B.1.
} 
Local History/Genealogy Centre ${ }^{102}$ in a new addition that connects the Heritage Gateway and the Welcome Centre This new fragment uses the traditional, local materials of reclaımed tımber and brick to create the atmosphere for tellıng the story of the city's history, but it employs these materıals in a contemporary manner to dıstınguısh the buildıng from the original fragments and to express its own lifetıme The Carnegie Lounge is an extension of this program that is suspended between the Constitution Buildıng and the old synagogue It relies on the support of the Constitution Buıldıng to allow it to hover over the synagogue, stealıng glances into its historical interior from above, where the lounge provides an intımate gatherıng and reading space that honours the city's first city library through the preservation of a precious fragment its orıgınal staıned glass wındow

Teen Services is essentially a teen community centre, featuring a black-box theatre, art dısplay areas, meetıng rooms, gamıng areas, and study spaces ${ }^{103}$ it is located behınd the Bytowne on the second and third floors of a new additıon Due to its unıque needs, it is situated away from the traditional library spaces in a location where teens can feel independent and unsupervised The fragment contınues the industrial and rough material palette of the Bytowne's rear facade to present a durable and unpretentious environment that teens can inhabıt with their own installatıons and artworks

Above the Bytowne Cinema there is a new fragment composed of glass and layers of perforated and stretched metal that houses the spaces for the library's Medıa and Technology Centre This materiality expresses the high-tech programs that are contained, including the Information commons computer workstatıons, technology classrooms and meetıng rooms, and digital desıgn centre, as well as the staff spaces for virtual library services, communications, and

\footnotetext{
${ }^{102}$ Ottawa Public Library, New Central Library, B 9

${ }^{103}$ Ottawa Public Library, New Central Library, B 4
} 
marketing. ${ }^{104}$ This low, two-storey addition with its translucent, layered cladding was positioned here to have minimal impact on the right to light and privacy for its residential neighbours. Between this new fragment and the existing Constitution Building are the staff spaces which are associated with the different levels of the library. They are situated directly adjacent to the elevators that transport the books from Materials Handling below to the library spaces on each level. The materiality of this fragment demonstrates its unique circumstance of being caught between the worlds of the traditional library and the contemporary office; here the materials transition from the precast panels of the Constitution Building to the layered metal facade of the Media and Technology Centre.

This arrangement of diverse new and old urban fragments is composed into a work of collage that combines the various expressions of civic life into the shared vision of Ottawa's identity. As a result, the unremarkable urban fragments are elevated and become the building blocks of important civic architecture. The layering and juxtaposition of the fragments and their meanings creates a new architectural language that celebrates diversity and idiosyncrasy, the very attributes of Ottawa's inconsistent urban fabric and its vibrant civic life. When appropriated for architectural purposes, the mechanisms of collage do not only allow for the celebration of material surfaces but also to the spaces between fragments. The space of the overlap and the connections between fragments generate incredible architectural moments that further celebrate the potential of the existing urban fabric.

The site plan, which is formed by the in-between spaces of existing and new urban fragments, exhibits a complex and varied web of pedestrian zones that enrich the city's public spaces. The carriageway that used to provide access to parking behind the Constitution building now acts as open atrium space, which guides pedestrians to the inner court that is now

\footnotetext{
${ }^{104}$ Ottawa Public Library, New Central Library, B.6.
} 


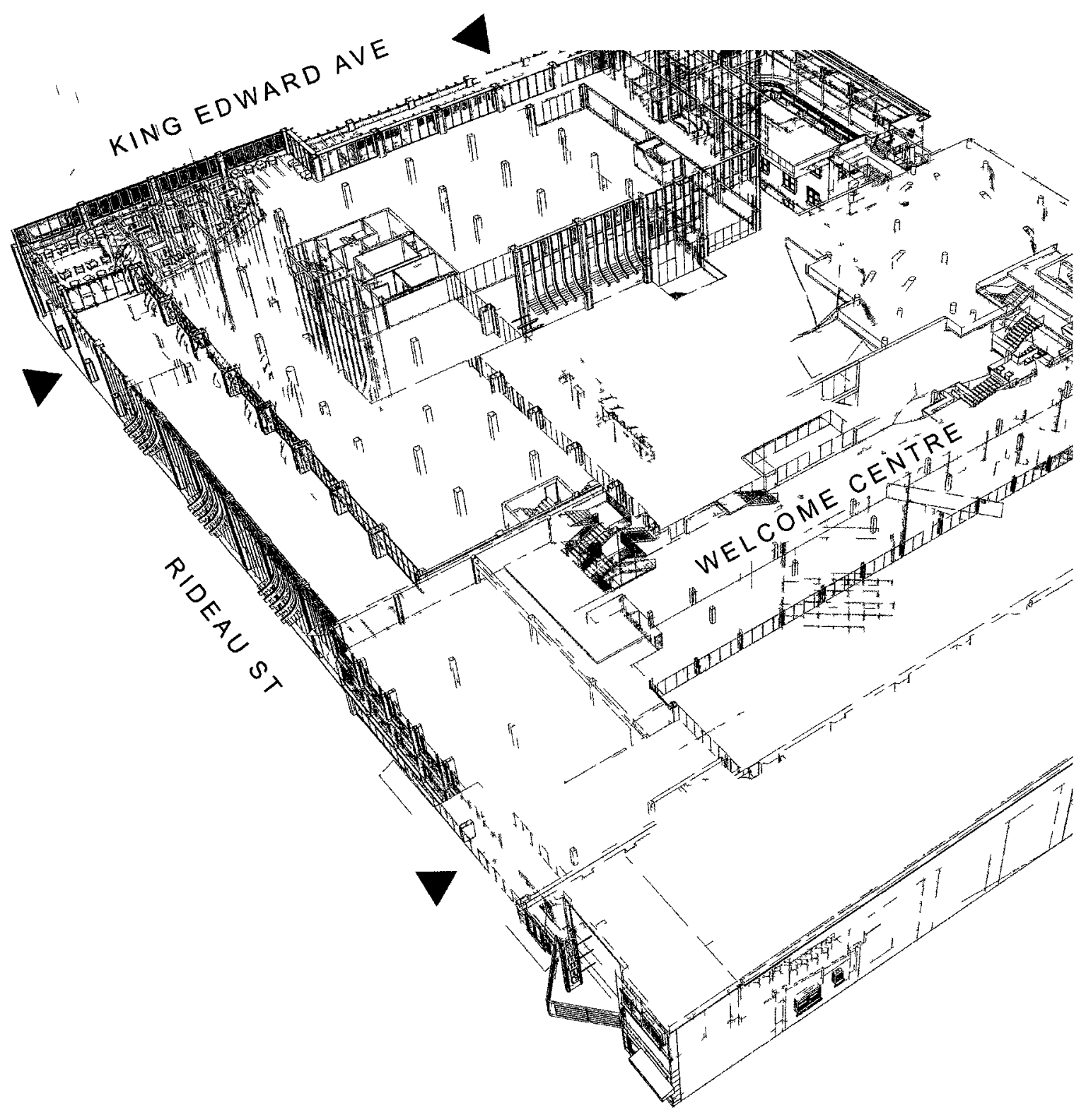

PEDESTRIAN PATHWAYS AT GRADE

[Plate 8] 
bounded by different fragments on all sides. The Carnegie Lounge creates a covered exterior walkway beside the old synagogue that creates a convenient access point for cyclists. The motel's carriageway now acts a vestibule area that connects the Business and Careers Centre with the Welcome Centre and Bytowne Cinema, providing a lobby and gathering space for events and festivals. The motel parking area is now a dynamic exterior courtyard and entry point that is partially covered by the classrooms connecting the Welcome Centre to the Media and Technology Centre.

There are additional opportunities for celebrating collaged space in the connection of fragments that don't actually touch, either by manipulating views between fragments or creating new connecting entities. The World News Centre of the Fiction/Newspapers and Magazines library is oriented both inside, to those in the library, and outside, to those inhabiting the inner courtyard. This allows pedestrians outside to view the centre's content on large screens, keeping them connected with the latest in world events and important breaking news. In order to provide more visible and accessible vertical circulation between the Welcome Centre and the different library levels, beyond the necessary fire stairs, new stair and walkway connections were added to the building's exterior. These connections are expressed on the exterior as metal tie rods that appear to physically pull the separate fragments together. The Media and Technology Centre is connected to the Welcome Centre with program elements, such as classrooms rather than circulation corridors, which are suspended above the courtyard and allow both components direct access to shared facilities. The new permanent exhibition spaces of the Heritage Gateway are connected to the old synagogue building through an intermediary, a glass stairwell that allows daylight to continue to penetrate the building's original windows. A door connects the now vacated space of the ark with the new stairwell, which uses daylight to 
draw attention to the void when it is open and provides a contemplative backdrop for the podium area when it is closed.

The final step in synthesizing the disparate fragments to create a new architectural expression of civic identity is the metamorphosis of the fragments. By following Schwitters' techniques of dividing, deforming, and painting over, the boundaries between the fragments are blurred, and they gain the ability to signify a shared vision. This process adds new meaning to fragments that could previously only express their past civic lives, allowing them instead to participate in forming the civic life of a new generation. Each existing fragment has been transformed in a different way based on the needs of its new programmatic functions, while ensuring that it maintains its ability to communicate its former life. The former synagogue has been pierced with careful surgical incisions that allow it to connect with its adjacent program spaces. Rounded windows are inserted into its vaulted ceiling that complement its existing architectural form and allow views from the Carnegie Lounge. An opening was carefully cut from the ark's original position to emphasize that which is missing and allow access to new spaces beyond.

The Constitution Building was deformed, as if it were made of clay, to give shape to its new program spaces and expose it to the life of the street. The corner has been pushed in to open the auditorium lobby to the public. The Fireside Amphitheatre of the Community Library has been pulled down to articulate the building entrance and to provide stepped seating. The facade surrounding the Children's Services reading spaces has been moulded to create intimate reading nooks. Other areas have been extended or depressed to give shape to particular functions, such as the Multi-faith Room, or increase the daylighting of particular library spaces. Floor areas of the library sections have been carved away to interconnect the spaces through views and additional vertical circulation. The resulting architectural expression maintains the 

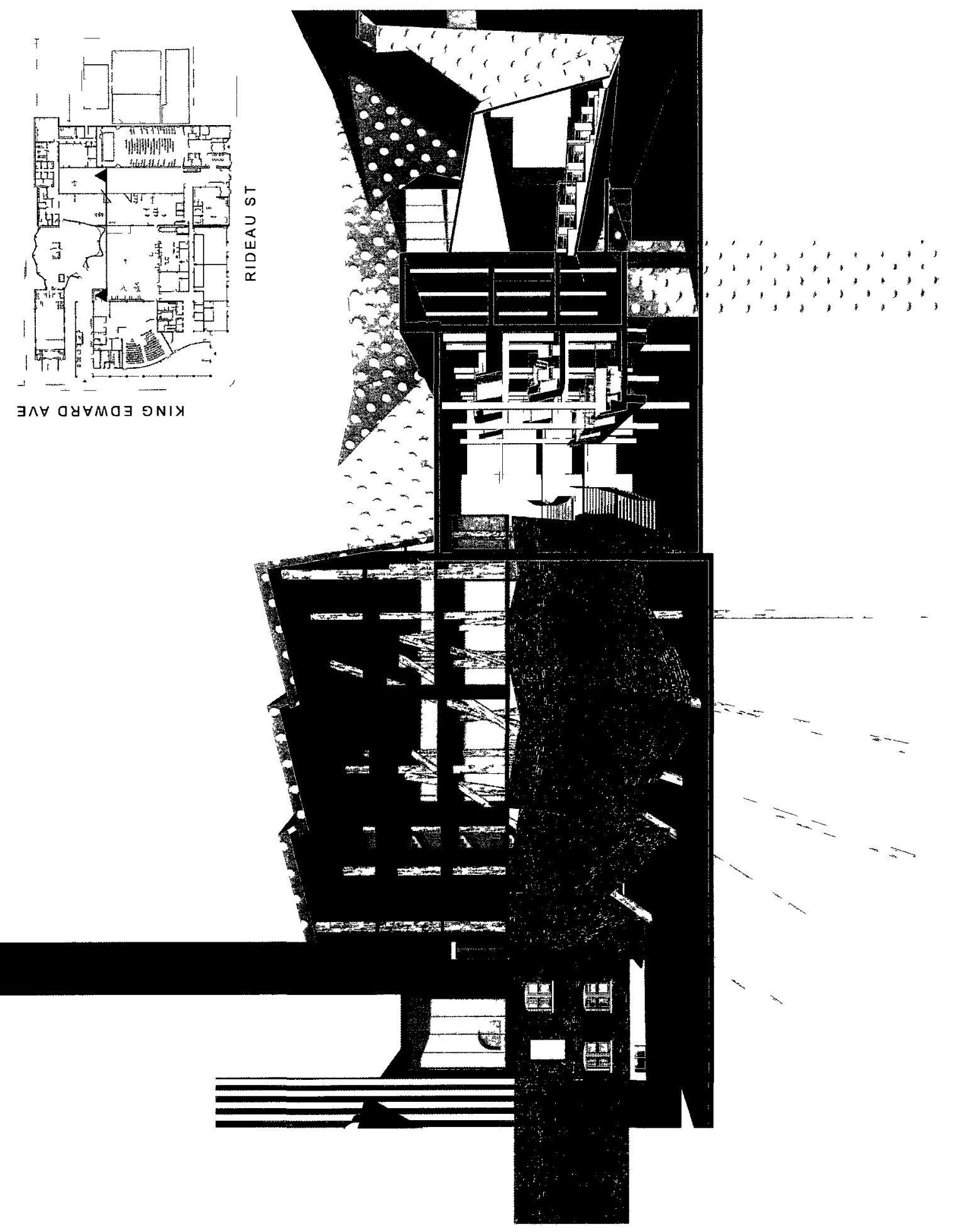

[Plate 9]

Synthesizing the Fragments 
original materials of precast concrete and glass to allow the building to communicate its story: that it is an original 1960 s office building that has been seized by the citizens who have reshaped it according to their own desires.

The body of the previous Town House Motor Hotel has been hollowed out, leaving a shell that denies its former use. The remaining husk creates a four-storey open atrium that contains the Welcome Centre. A new circulation corridor has been added along its east elevation, to which information pods have been docked through the openings for the windows of the original suites. Since the Bytowne Cinema retains its original functions, its interior spaces remain unaltered. However, its west wall now kneels towards the library, offering support to the classrooms which are suspended over the courtyard. The new fragments, which were made specifically to suit their new functions and surroundings, do not require these kinds of deformations; however, all fragments are synthesized through over-painting and metamorphic transition spaces to unify the building into a single architectural entity.

Although it is possible, from the interior and exterior, to identify each individual fragment as the originator of a unique material expression, the boundaries that delineate one fragment from another are unclear. The materials from one element have been extended over the next, unifying the fragments through material synthesis. The masonry facades of the old synagogue transition to a more contemporary expression in the new portion of the Heritage Gateway. The precast fins of the Constitution Building extend beyond its boundaries, intertwining with the new tower of staff spaces. The metal layers of the Media and Technology Centre are not bound to its rectangular form but extend across the facades of other components. On the interiors, new horizontal and vertical connectors create material transitions by extending the material language of one interior to the next. 
In the design of the Ottawa Central Library, the preservation and celebration of the urban fragments generate new architectural spaces and connections, and their transformation creates a new language of architectural synthesis. However, these innovations do not only provide Ottawa with the sought after "stamp of originality"; their deeply rooted connection to the city's reality enables the resulting civic architecture to achieve the level of insignificance necessary to prove that it has, in fact, created a new civic identity. By providing a recognizable representation of the city's present reality and a vision for its future, the project involves the citizens in a public discussion about civic architecture and demonstrates how they can actively participate in the development of future representations of Ottawa's identity. In the end, the initiation of this civic discourse and participation is far more significant than the architecture itself. 


\section{[Conclusion]}

The purpose of the new Central Ottawa Library project is to create civic architecture that inspires the citizens of Ottawa to recognize the value of the city's existing urban fabric and its potential to represent their civic identity. The project encourages the citizens to take pride in and ownership of the human aquariums that support their civic life, which are currently either avoided or thoughtlessly demolished. It proposes a new vision for the city that is derived not from the imitation of imported foreign concepts of identity but from a careful study of the city's own "fundamental reality." ${ }^{105}$ It establishes a new medium for civic representation that no longer relies on national monuments, which have proven to be inadequate as expressions of local identity.

The overzealous attempt to represent the national identity in Ottawa's architecture, combined with a disinterest in the expression of the citizens' values, has given rise to the general feeling that the city is "singularly lacking in a symbol of city life"106 and that its urban fabric is "purely unremarkable." ${ }^{107}$ Although this feeling of civic disappointment provided the impetus for this thesis' investigations, these statements were not merely accepted as mattersof-fact. Instead the thesis committed to investigating the city's current condition from the point of view of Agamben's "Contemporary" to uncover the hidden reality that has thus far evaded architectural expression. It then used the example of Gaudís work in Barcelona to demonstrate that, by developing innovative architectural solutions to convey this newly discovered reality, architecture acquires the capacity to embody the values of the citizens. The intent of this

\footnotetext{
105 Ingersoll, "Conference Review," 125.

${ }^{106}$ Ottawa Public Library Board, New Central Library, 8.

${ }^{107}$ Wieclawski, "Design lost on city council."
} 
process is to generate a new architectural vision that is unconventional and remarkable, which causes one to take notice and ponder its meaning. Conversely the resulting vision will also display an intimate level of familiarity, which will allow the citizens to recognize its source: roots that are firmly entangled in the city's unique identity.

Since it is clear that Ottawa's city life cannot be discerned from the surface of its urban fabric, this thesis concluded that the contemporary investigation of its present would have to be conducted from "within." This entailed exploring the city from the citizen's perspective and revealed the hidden potential of the city's unremarkable fabric to express the vibrant life it shelters. Based on this discovery, the project sought to preserve the important fragments of civic identity in its proposal for the new Ottawa Central Library. By including the discordant fragments of an old synagogue, an office tower, a motel, and a cinema in the new building, it sustains the past lives these buildings have harboured and the roles they have played in forming the city's identity. By providing them with new library functions, the project enables them to continue to participate in shaping the lives of a new generation. The project also preserves the logic of the existing urban fabric in the design of new additions, which exhibit a diverse range of material and formal expressions that have been dictated by their unique functional requirements.

Yet preservation alone cannot adequately protect these unremarkable urban fragments from demolition. In order to understand how these worthless fragments can be given value, the thesis looks to the lessons of collage, an artform that successfully raised discarded and worthless materials to the status of important signifiers of artistic meaning. These lessons were incorporated into the project's treatment of the fragments: in their composition, layering, juxtaposition and interconnection. The resulting architecture exhibits not only a celebration of the individual fragments and their meanings but also of the remarkable spaces and unique 
environments that they are capable of generating when composed into a larger work of architectural collage.

Lastly, this thesis establishes that, if the city's disparate fragments are to participate in the creation of a new vision for the future, then they must communicate not only their disparate individual meanings but also a new common message. They must be synthesized into a new architectural whole that projects a united front. This will allow for the diverse expressions of the citizens' values to be finally unified into a comprehensive expression of civic identity. The project draws inspiration from Kurt Schwitters' Merz works to develop methods for creating architectural synthesis, such as transformation and metamorphosis. It deforms the existing fragments and blurs their material boundaries to bind the fragments together and express their shared purpose. Through this final step, the project generates an original architectural expression that is capable of redefining the city's identity through a "Spectacle of Substance".

The result of the Ottawa Central Library project is a new civic monument that presents a remarkable and convincing precedent for the preservation, celebration, and creation of the city's unique identity. It aims to not only provide the city with a singular expression of the citizens' values but to elevate the importance of the entire urban fabric by demonstrating its potential to communicate the city's vibrant life and participate in a new vision for the future. By celebrating the value of the Ottawa's inconsistent urban massing it challenges the city's illconceived plan to superficially replicate the consistent civic identity of foreign cities. It revives the social agenda of Modern architecture and criticizes the recent use of Modernist architectural language for purely aesthetic purposes. The Ottawa Central Library project imagines a new future for Ottawa, one in which the citizens are proud of their civic architecture and recognize in its physical qualities reflections of their own values. This future is only one building away. 


\section{[Bibliography]}

Agamben, Giorgio. "What Is the Contemporary?" In What Is an Apparatus? and Other Essays, 39-54. California: Stanford University Press, 2009.

"A Lesson for Europe from Nate's Deli." National Post, May 29, 2010. Accessed February 13, 2011. http://fullcomment.nationalpost.com/2010/05/29/a-lesson-for-europe-from-natesdeli/

Aragon, Louis. Paris Peasant. Boston: Exact Change, 1994.

City of Ottawa. Corporate Services and Economic Development Committee. Report 44. Ottawa: City of Ottawa, 2009

City of Ottawa. Ottawa Public Library. New Central Library: Functional Building Program, Resource Planning Group Inc. (Confidential Final Draft) Ottawa: Ottawa Public Library, March 2009.

City of Ottawa. Ottawa Public Library Board. New Central Library: Functional Building Program, prepared by Barbara Clubb and Elaine Condos. (Doc. P1) Ottawa: Ottawa Public Library Board, June 10, 2009.

City of Ottawa. Uptown Rideau: Community Design Plan, Rideau Street Redevelopment Working Group. Ottawa: City of Ottawa, 2005.

Dietrich, Dorothea. The Collages of Kurt Schwitters: Tradition and Innovation. New York: Cambridge University Press, 1993.

Frampton, Kenneth. “Prospects for a Critical Regionalism." Perspecta Vol. 20 (1983): 147-162.

Gruft, Andrew. Introduction to Substance over Spectacle: Contemporary Canadian Architecture, edited by Andrew Gruft, 7-17. Vancouver: Arsenal Pulp Press, 2005.

Hadaya, Hagit. "Lack of Parking May Doom Ottawa's Oldest Synagogue." Jewish Heritage Report Vol. II, No. 1-2 (1998)

Hadaya, Hagit. "The First Synagogues in Ottawa." Society for the Study of Architecture in Canada Bulletin Vol. 19, No. 2 (1994): 76-82.

Ingersoll, Richard. "Conference Review: Context and Modernity: Delft, June 12-15, 1990." Journal of Architectural Education (1984-) Vol. 44, No.2 (1991): 124-125.

Lahuerta, Juan José. Antoni Gaudi 1852-1926: Architecture, Ideology and Politics. Milano: Electa Architecture, 2003. 
Lees, David. Capital Realty Management Corp.: Constitution Building (Rideau). Ottawa: Royal LePage, 1985.

McKay, Sherry. "Ideas of Canadian Architecture." In Substance over Spectacle: Contemporary Canadian Architecture, edited by Andrew Gruft, 191-201. Vancouver: Arsenal Pulp Press, 2005.

Miguelez, Alain. A Theatre Near You: 150 Years of Going to the Show in Ottawa-Gatineau. Canada: Penumbra Press, 2004.

Permanyer, Lluis. Gaudi of Barcelona. New York: International Publications, Inc., 1997.

Polo, Marco. "Mannered Modernism: Fifteen Years of Canadian Architecture." In Substance over Spectacle: Contemporary Canadian Architecture, edited by Andrew Gruft, 213-223. Vancouver: Arsenal Pulp Press, 2005.

Rowe, Colin, and Fred Koetter. Collage City. Massachusetts: MIT Press, 1978.

Taylor, Brandon. Collage: The Making of Modern Art. New York: Thames \& Hudson, 2004.

Warncke, Carsten-Peter. Pablo Picasso: 1881-1973. Cologne: Taschen, 2003.

Wieclawski, Tim. "Design lost on city council, says architect." Metro Ottawa, December 9, 2009. Accessed October 6, 2009. http://www.metronews.ca/ottawa/local/article/391895--designlost-on-city-council-says-architect.

"Wreckers send remains of Nate's Deli into Ottawa's dusty memory." Ottawa Citizen, August 26, 2010. Accessed February 13, 2011.

http://www.ottawacitizen.com/life/Wreckers+send+remains+Nate+Deli+into+Ottawa+dusty +memory/3442783/story.html 


\section{[Existing Ground Floor Plan]}

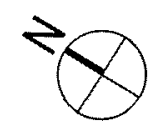

IS NOS7ヨN
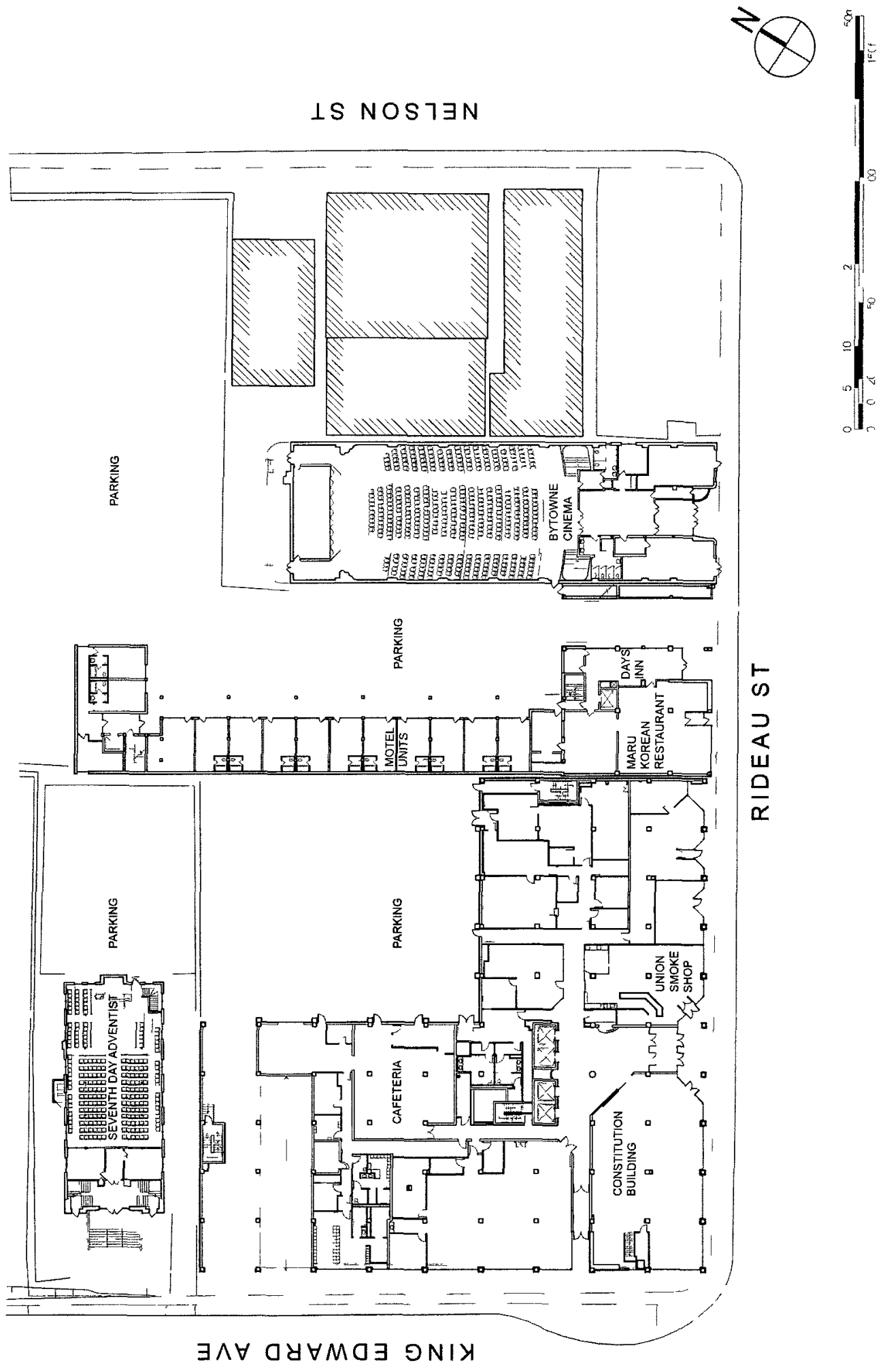
[Proposed Ground Floor Plan]

IS NOS7ヨN
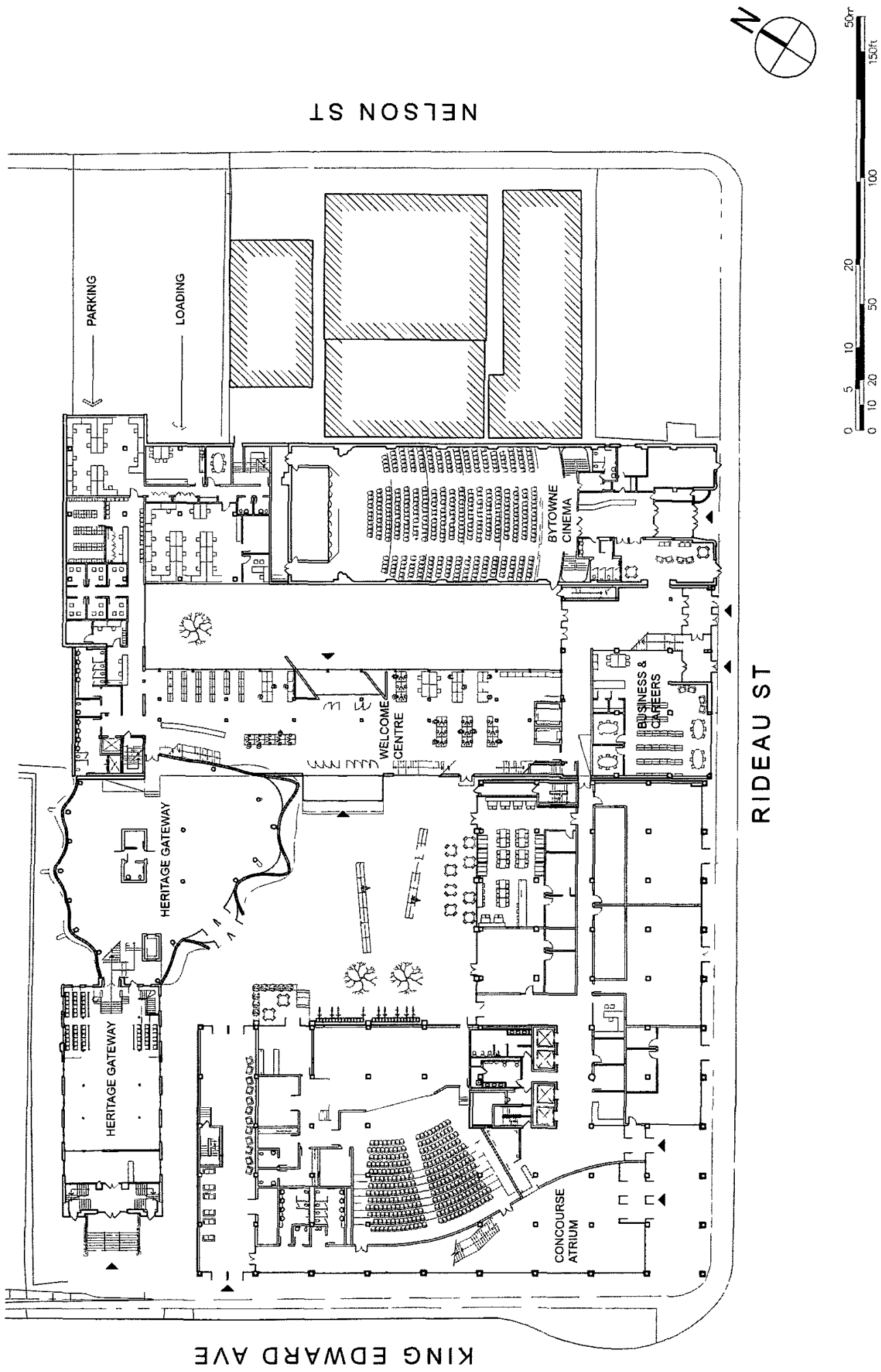


\section{[Existing Floor Plans]}

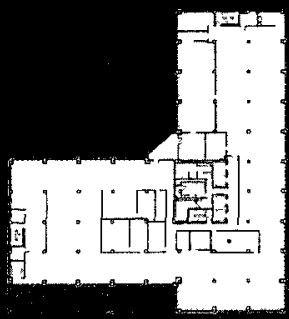

$N$
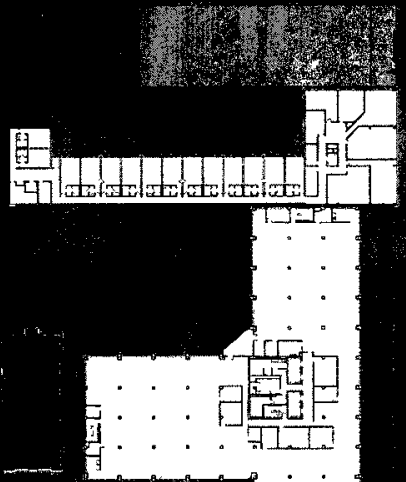

$\forall$

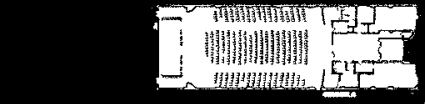

早

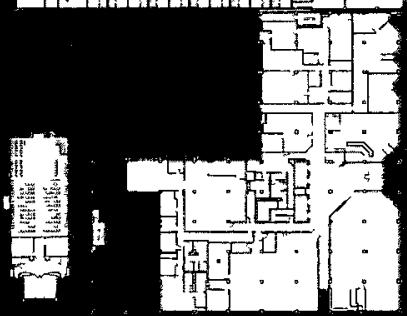

F

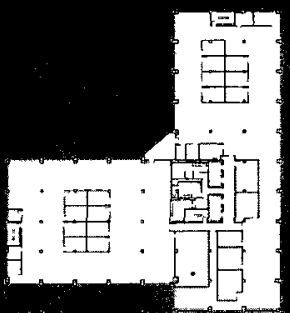

$\infty$

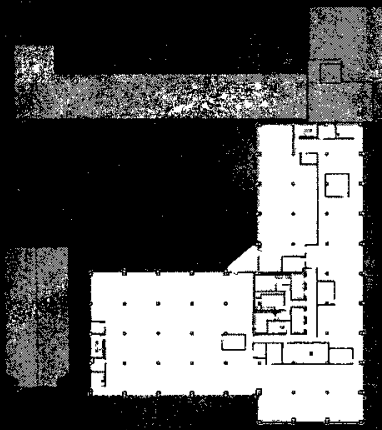

10

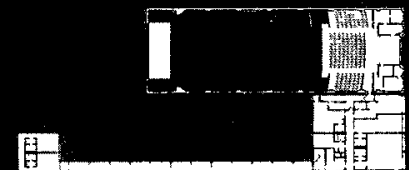

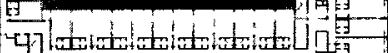

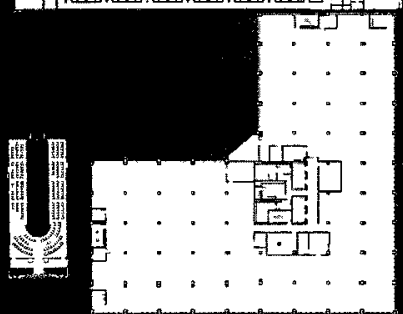

V

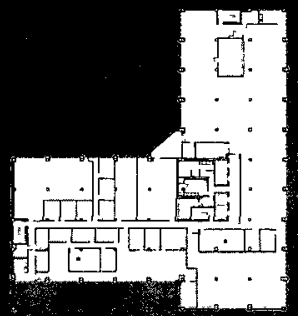

$\boldsymbol{\infty}$

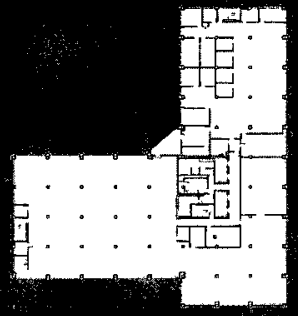

$\infty$

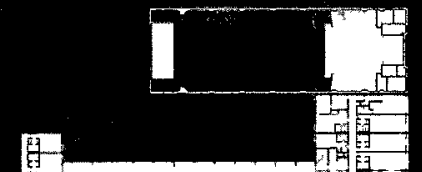

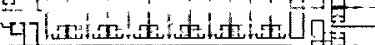

과느:

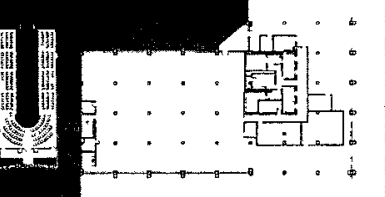

$m$ 
[Proposed Floor Plans]

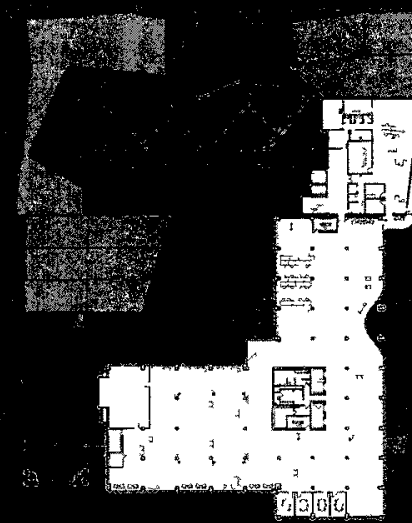

$N$

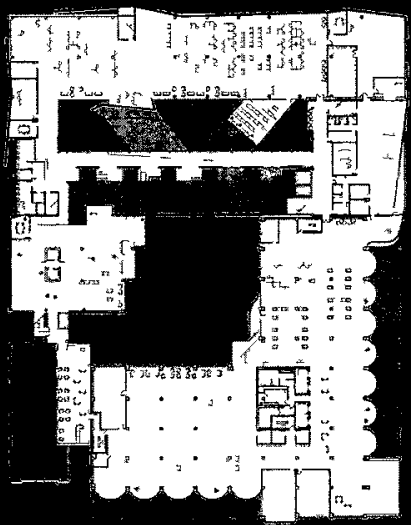

$\checkmark$

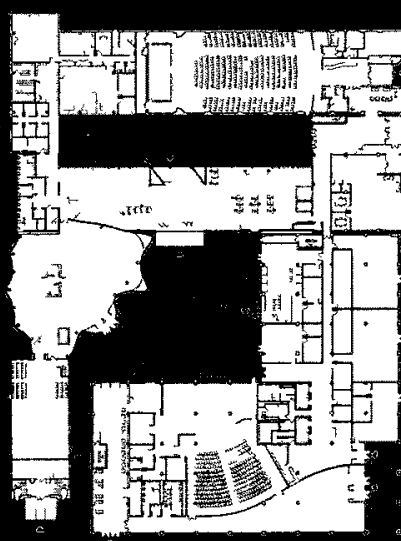

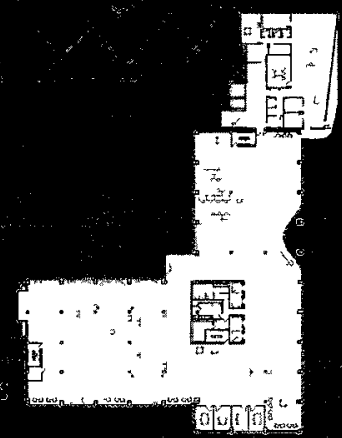

$\infty$

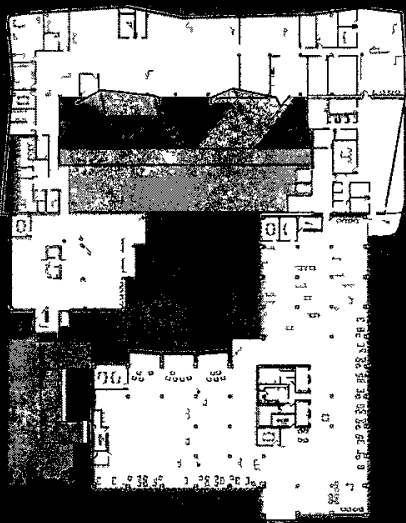

19

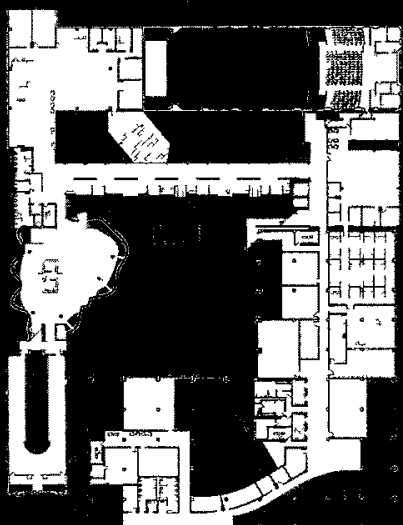

N

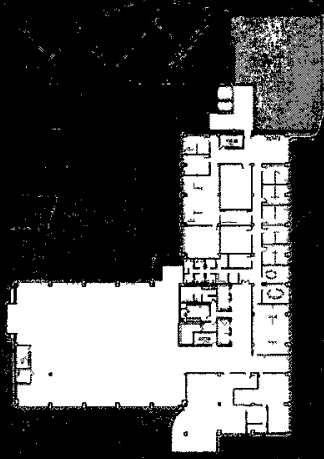

()

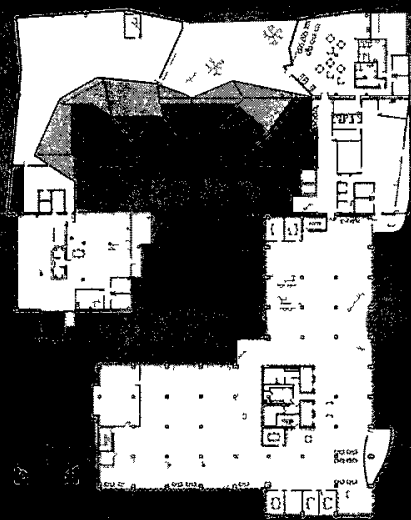

10

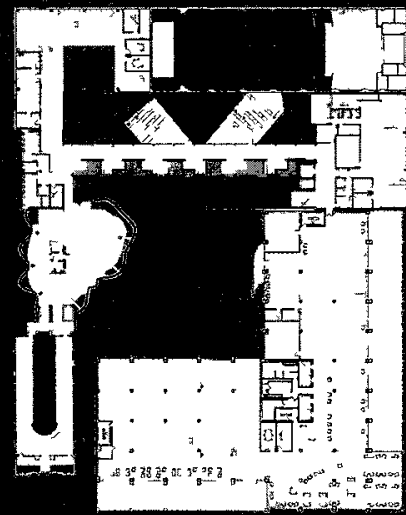

क 


\section{[Massing Model Photographs]}
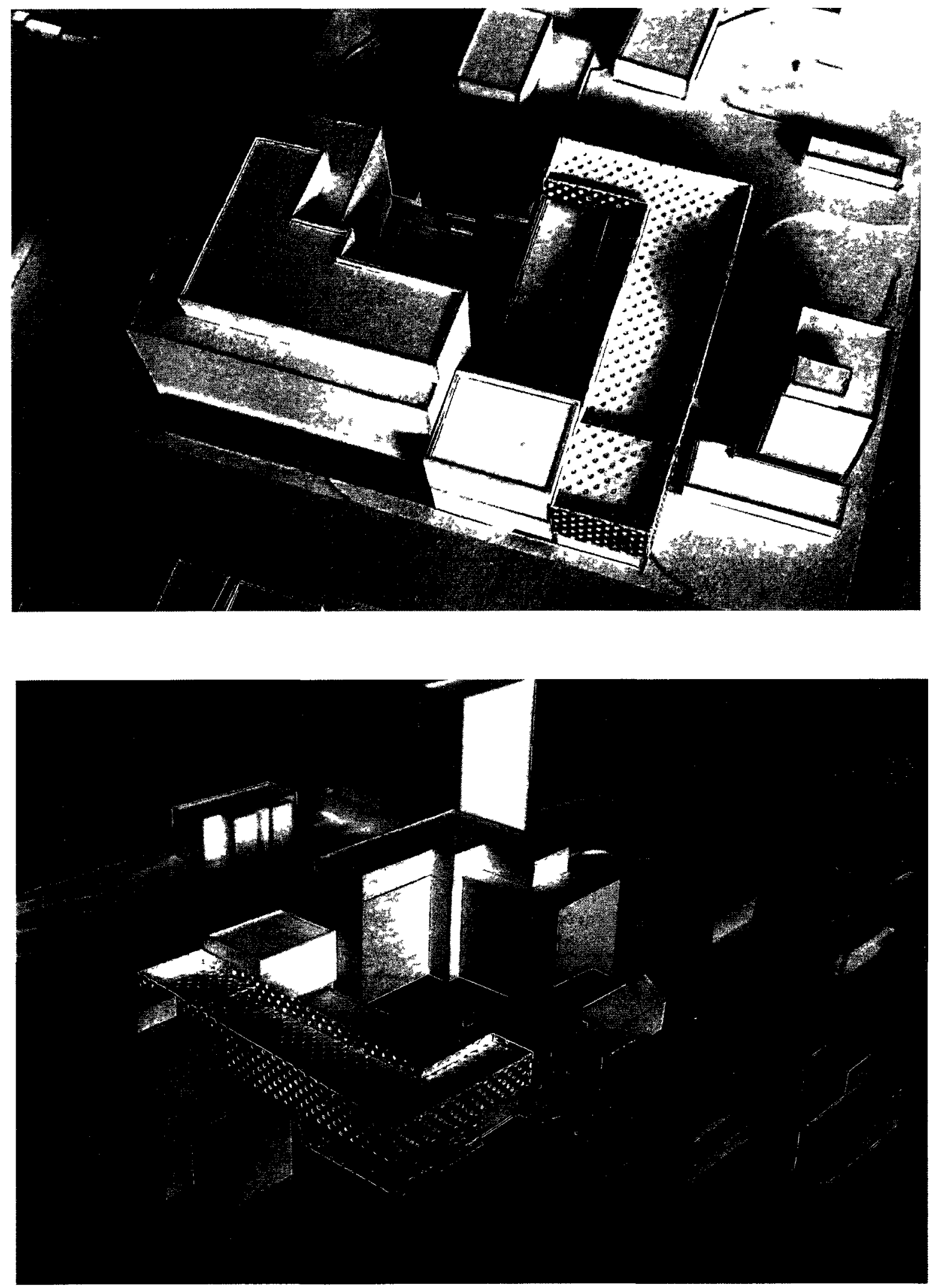


\section{[Concourse Atrium Plans]}

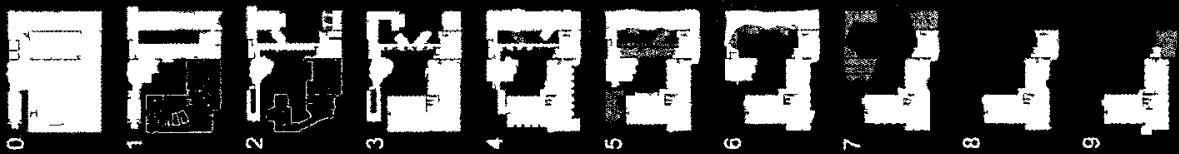

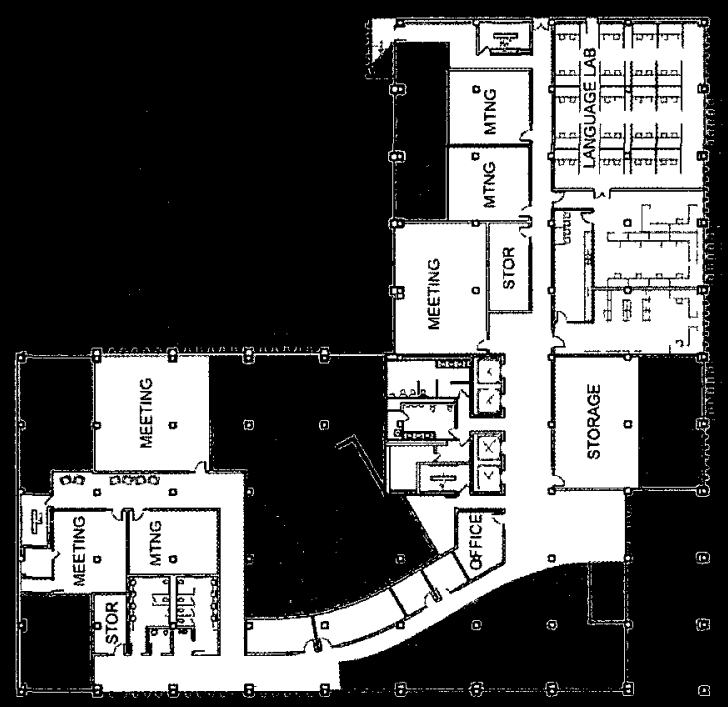

N

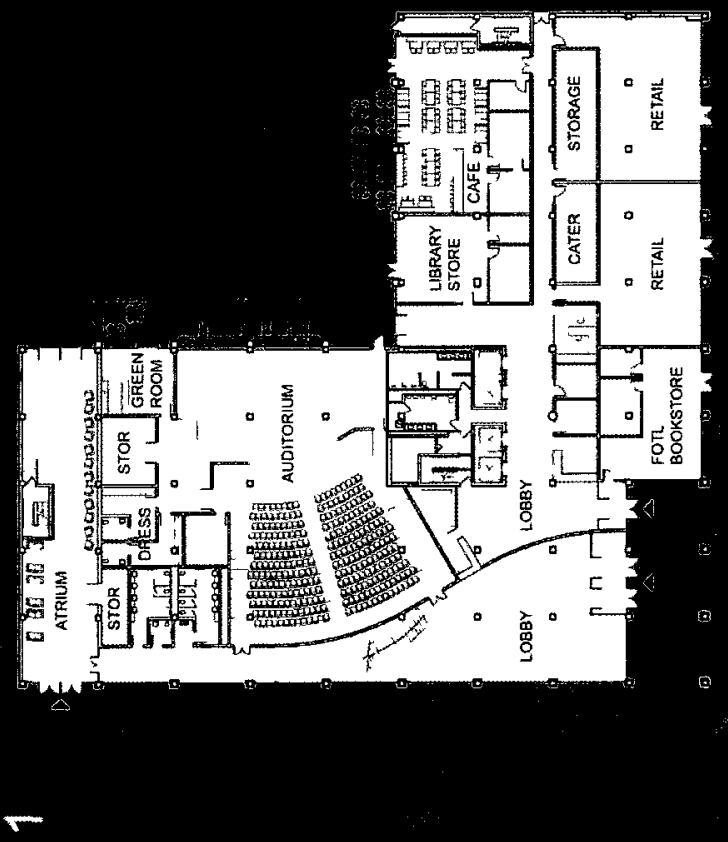




\section{[Concourse Atrium Perspectives]}

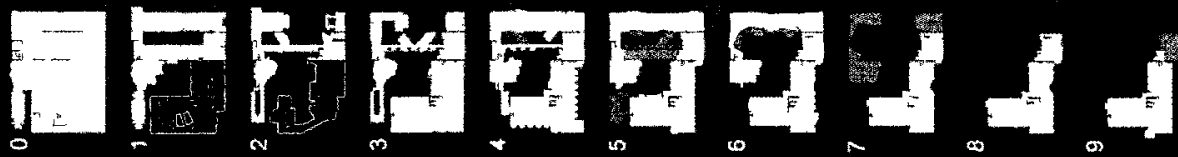

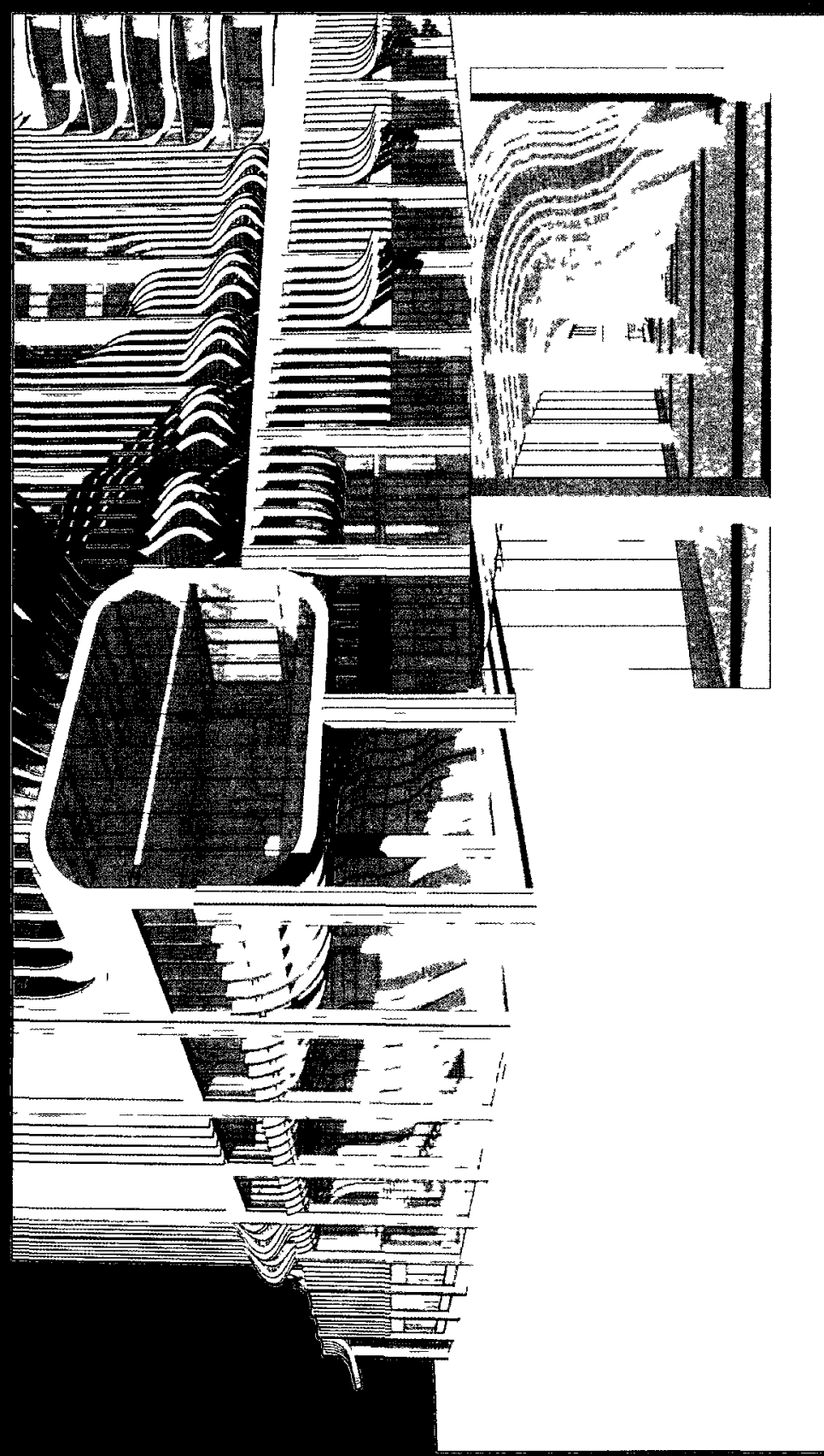


[Heritage Gateway Plans]

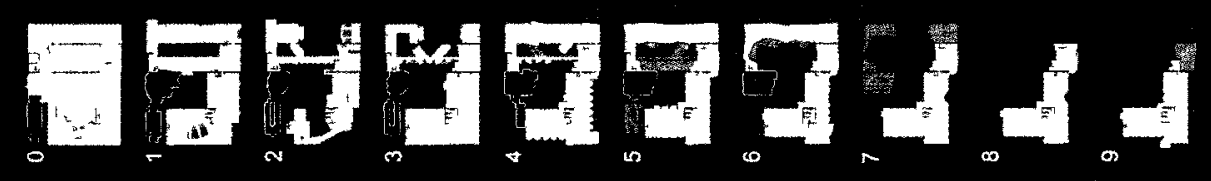

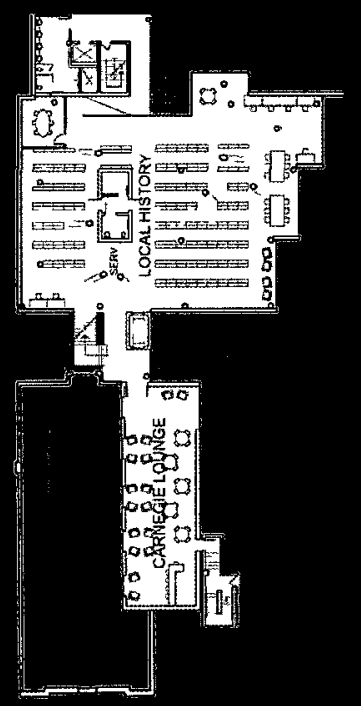

$\forall$

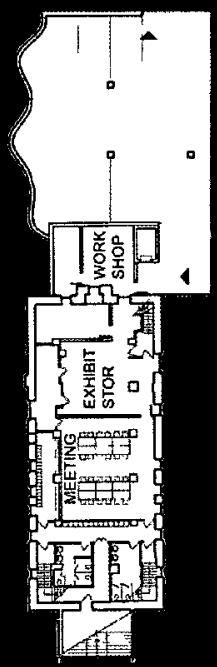

○

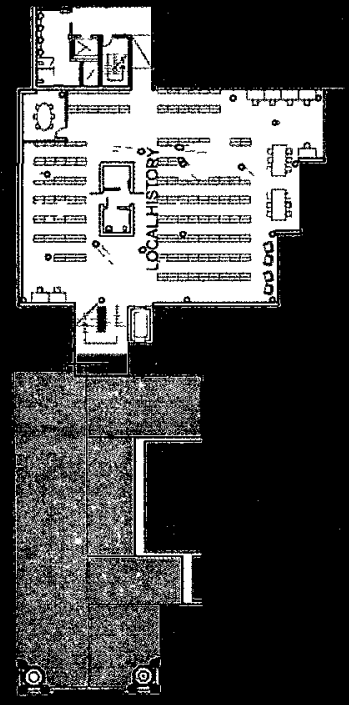

10

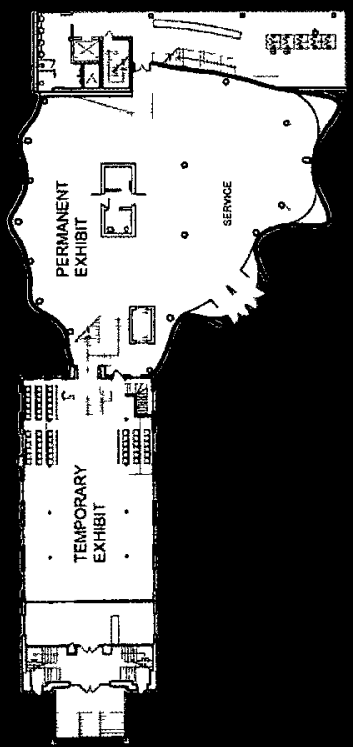

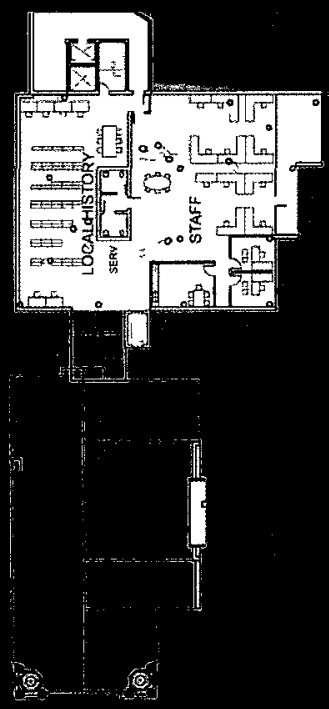

$\infty$

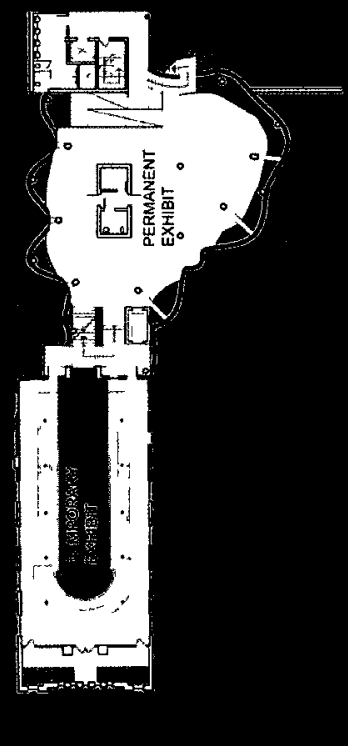

$N$ 
[Heritage Gateway Perspectives]
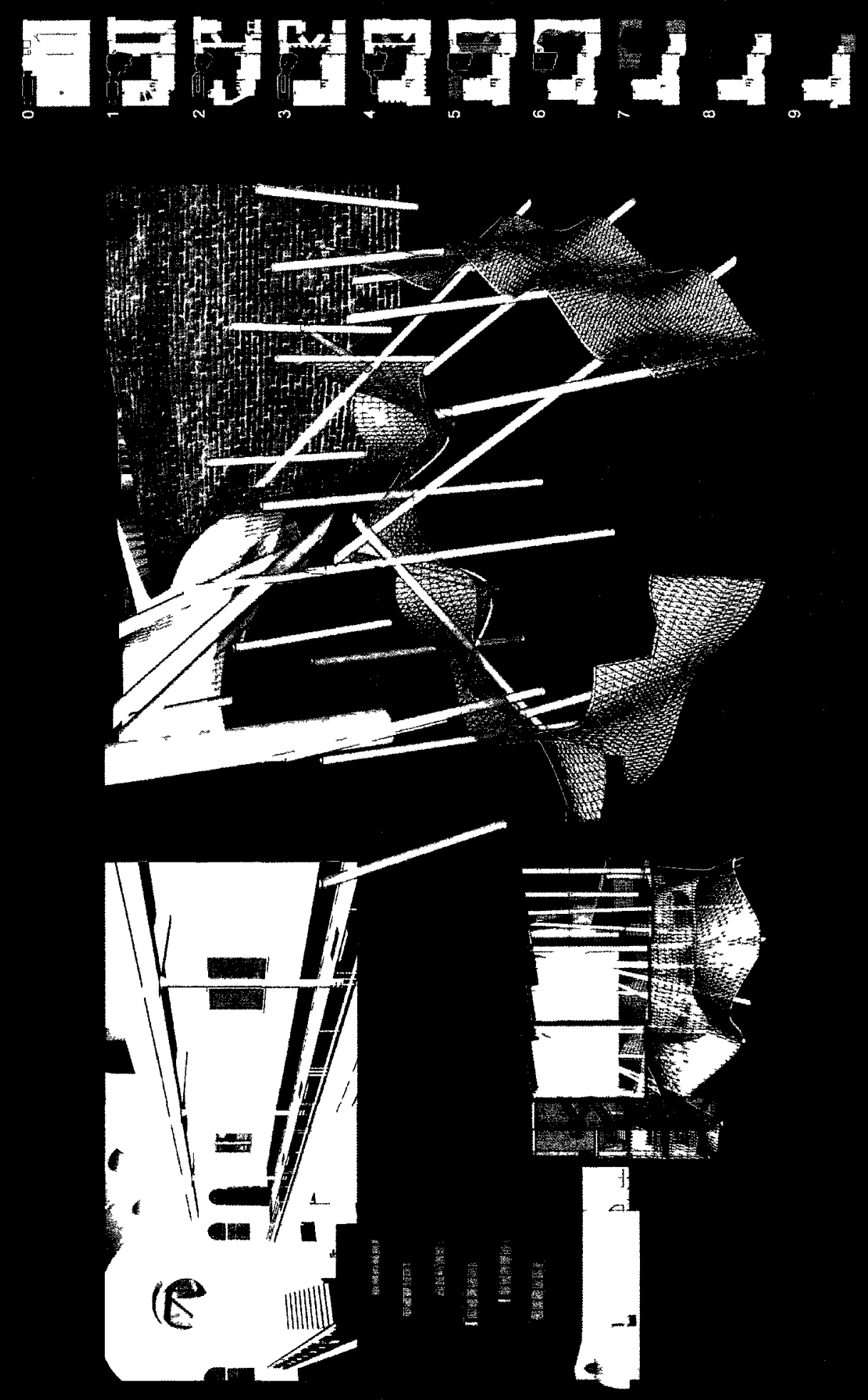
[Business \& Careers Centre and Language \& Literacy Centre Plans and Perspective]

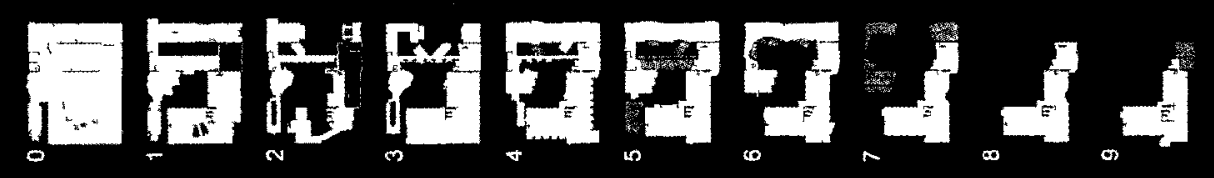

$-$

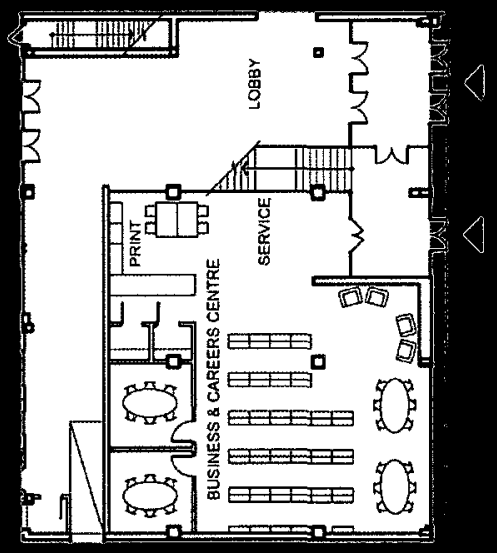

N

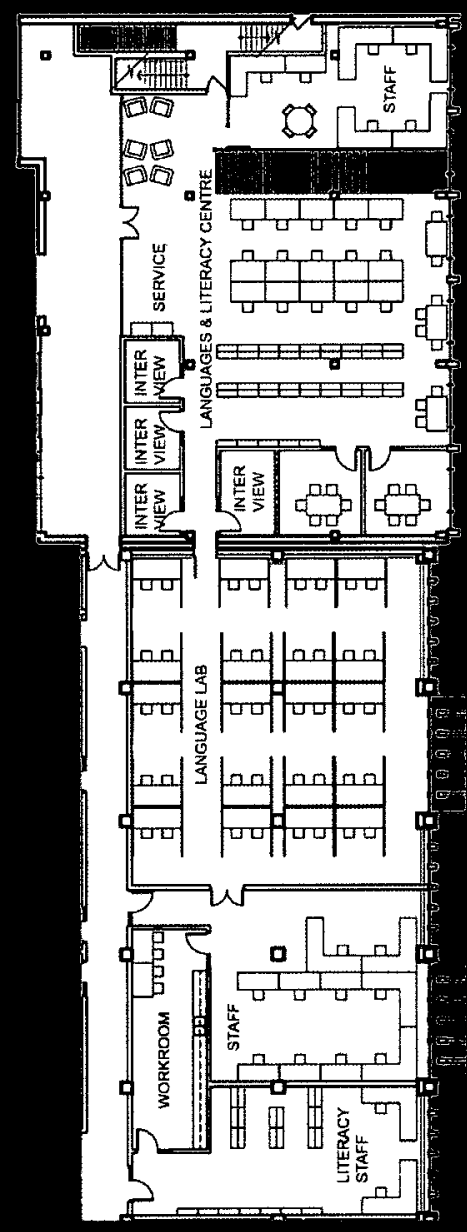




\section{[Welcome Centre Plans]}

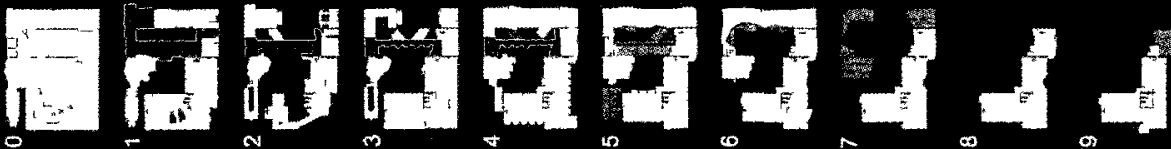

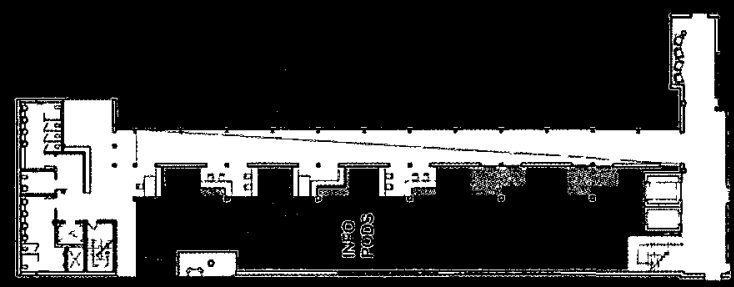

$\forall$

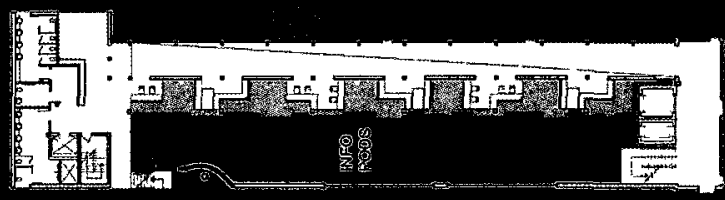

$m$

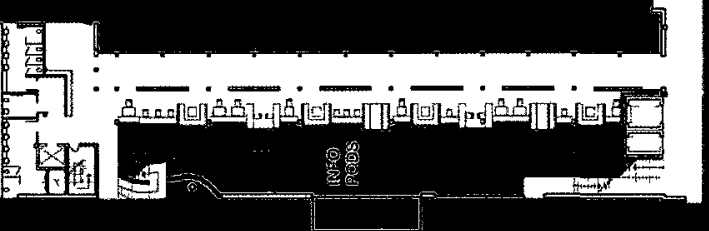

N

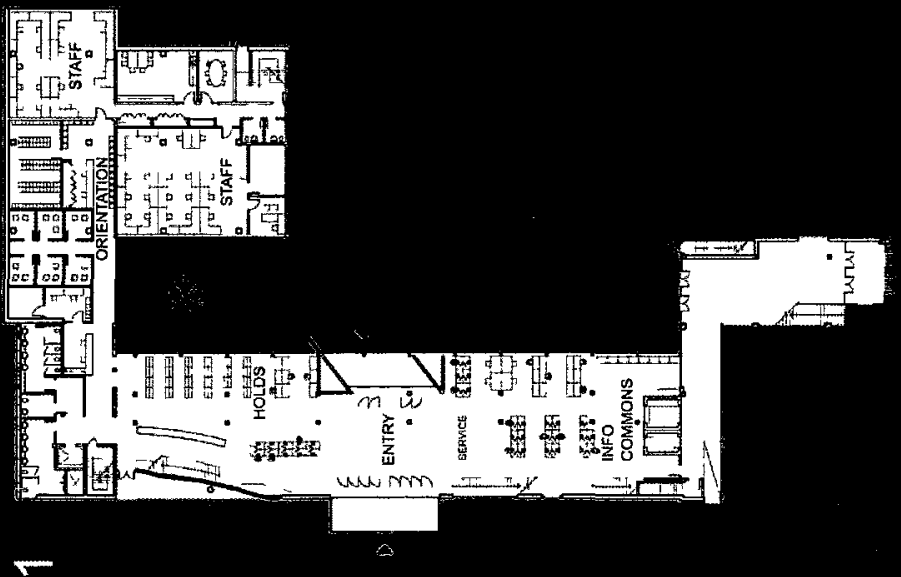


[Welcome Centre Sections]

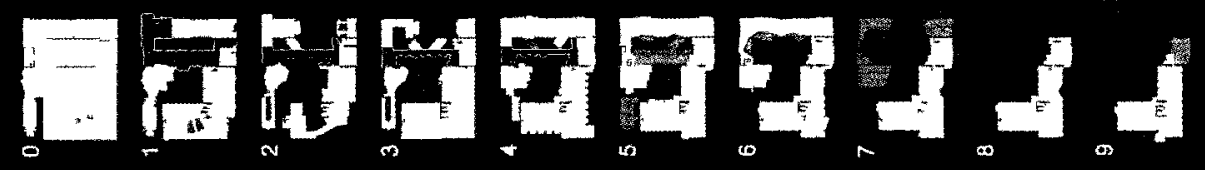
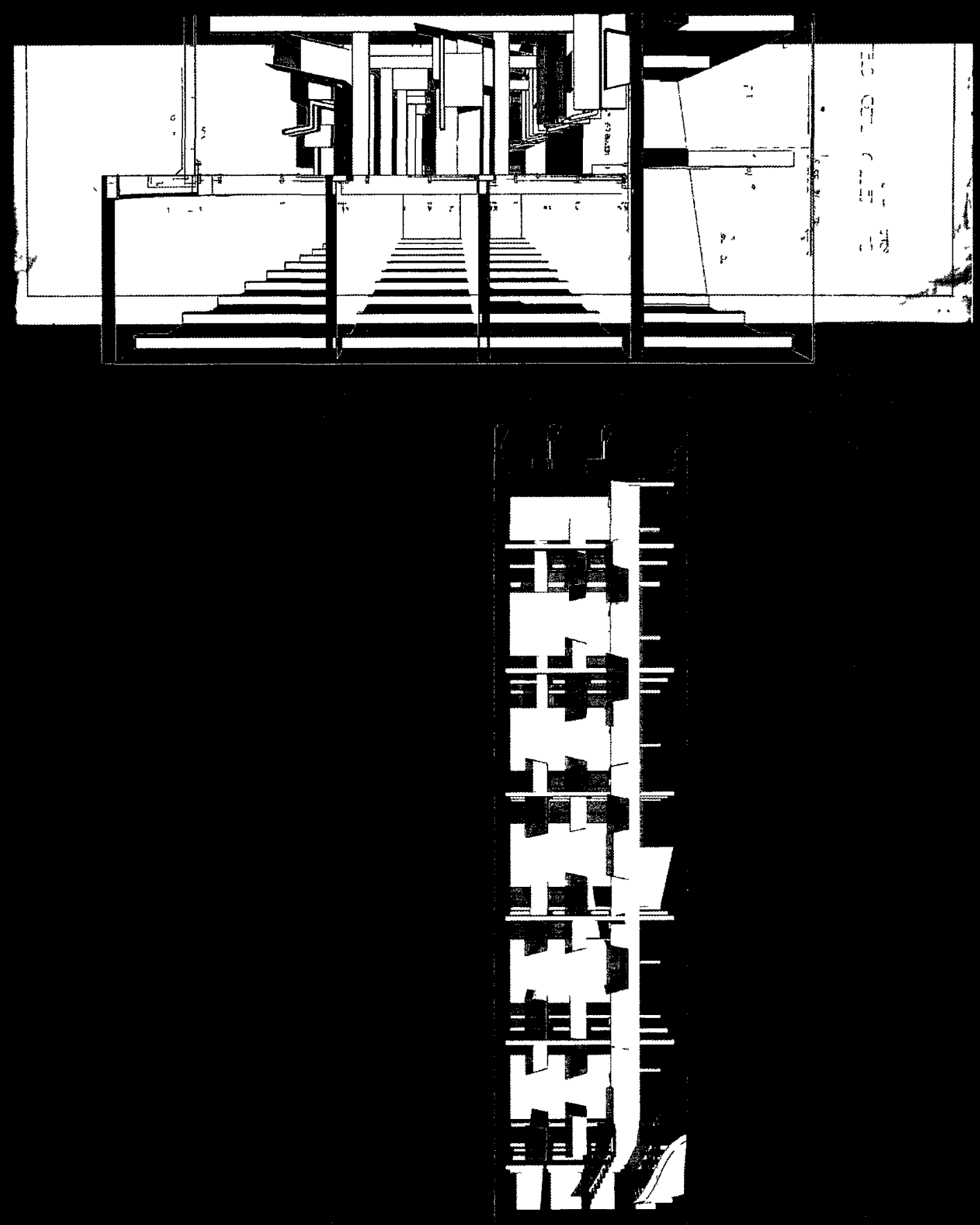


\section{[Teen Services Plans]}

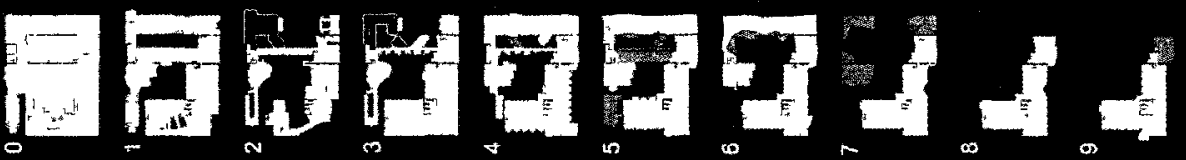

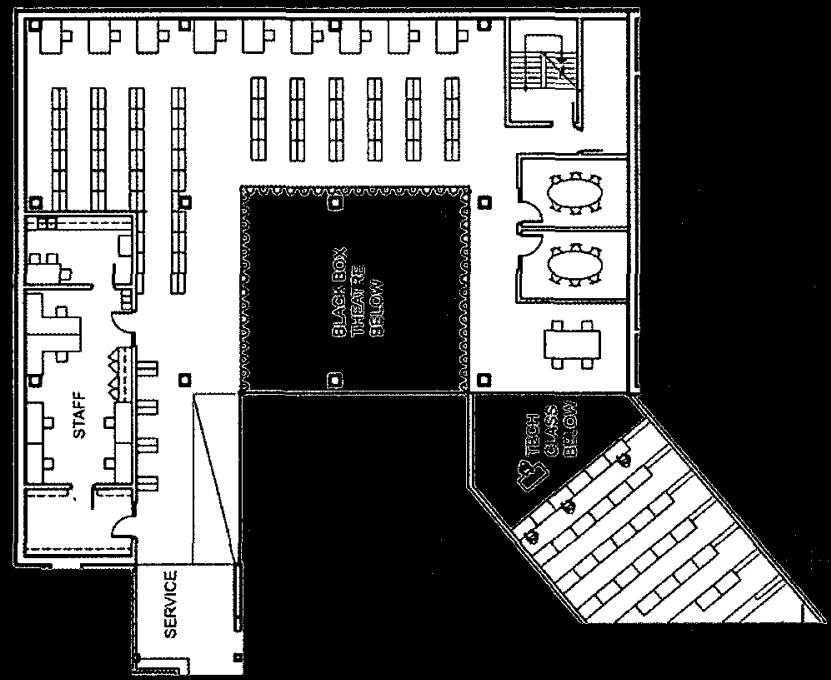

$m$

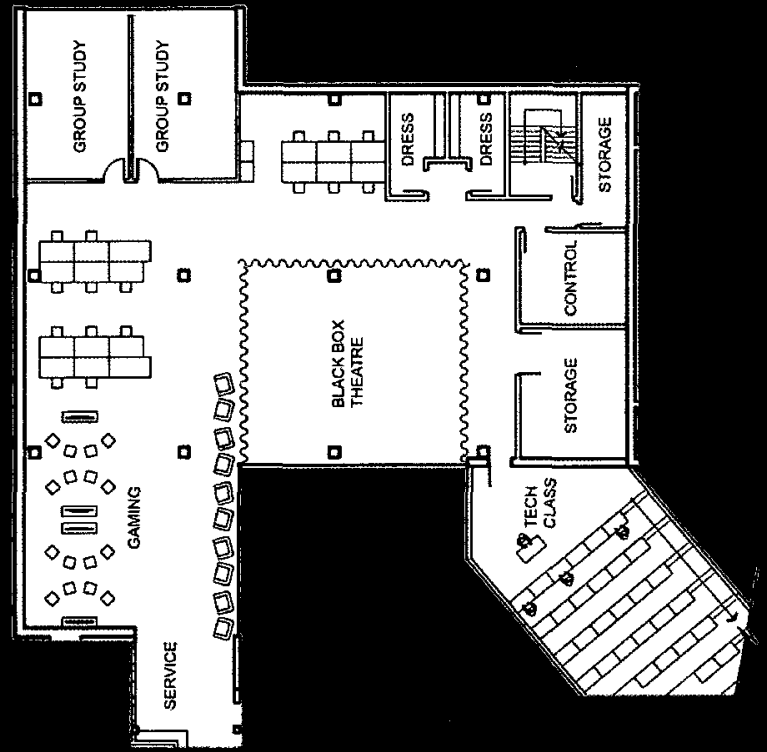

$\mathbf{v}$ 


\section{[Community Library Plan and Perspective]}
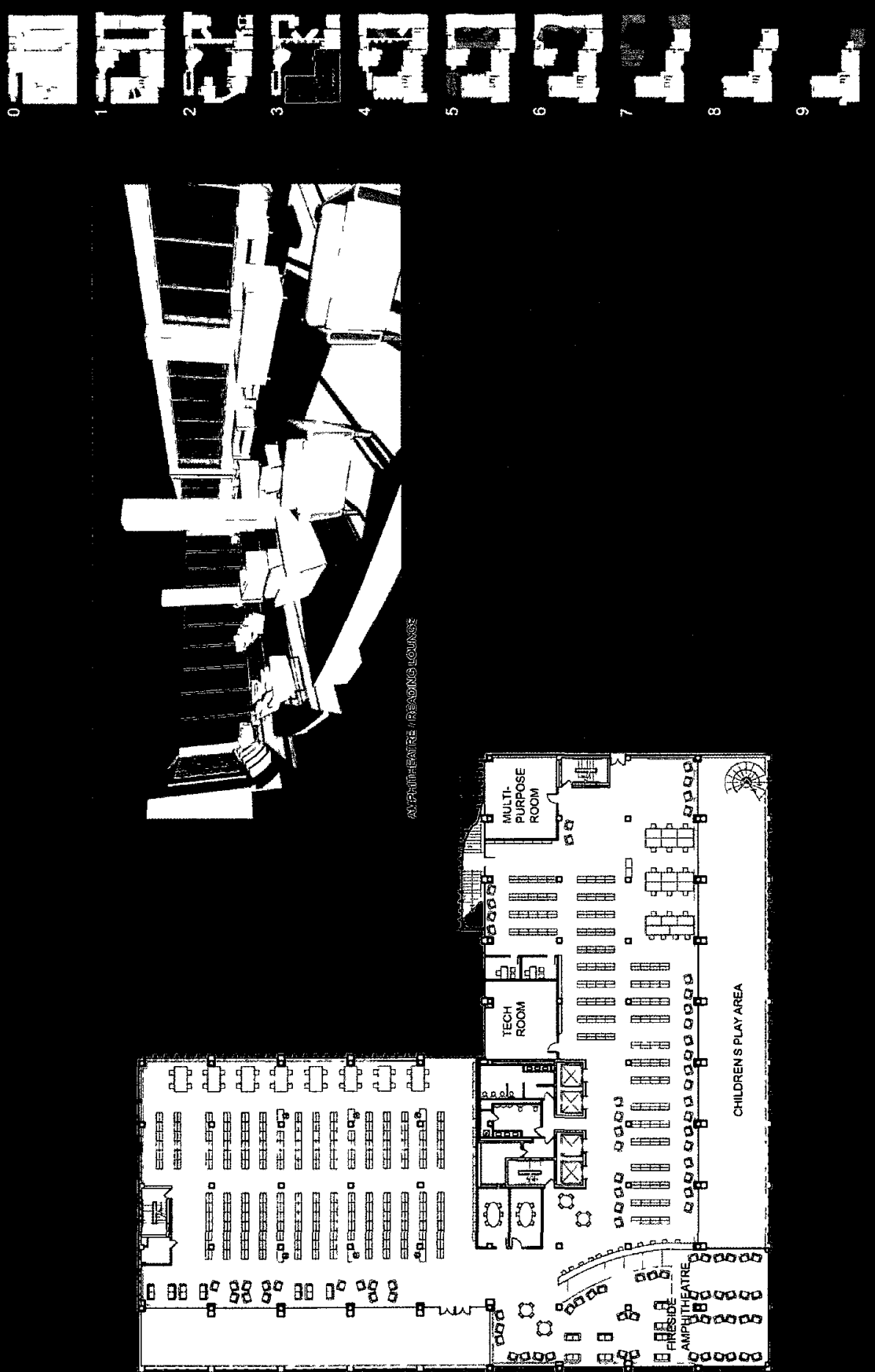


\section{[Children's Services Plan and Perspective]}
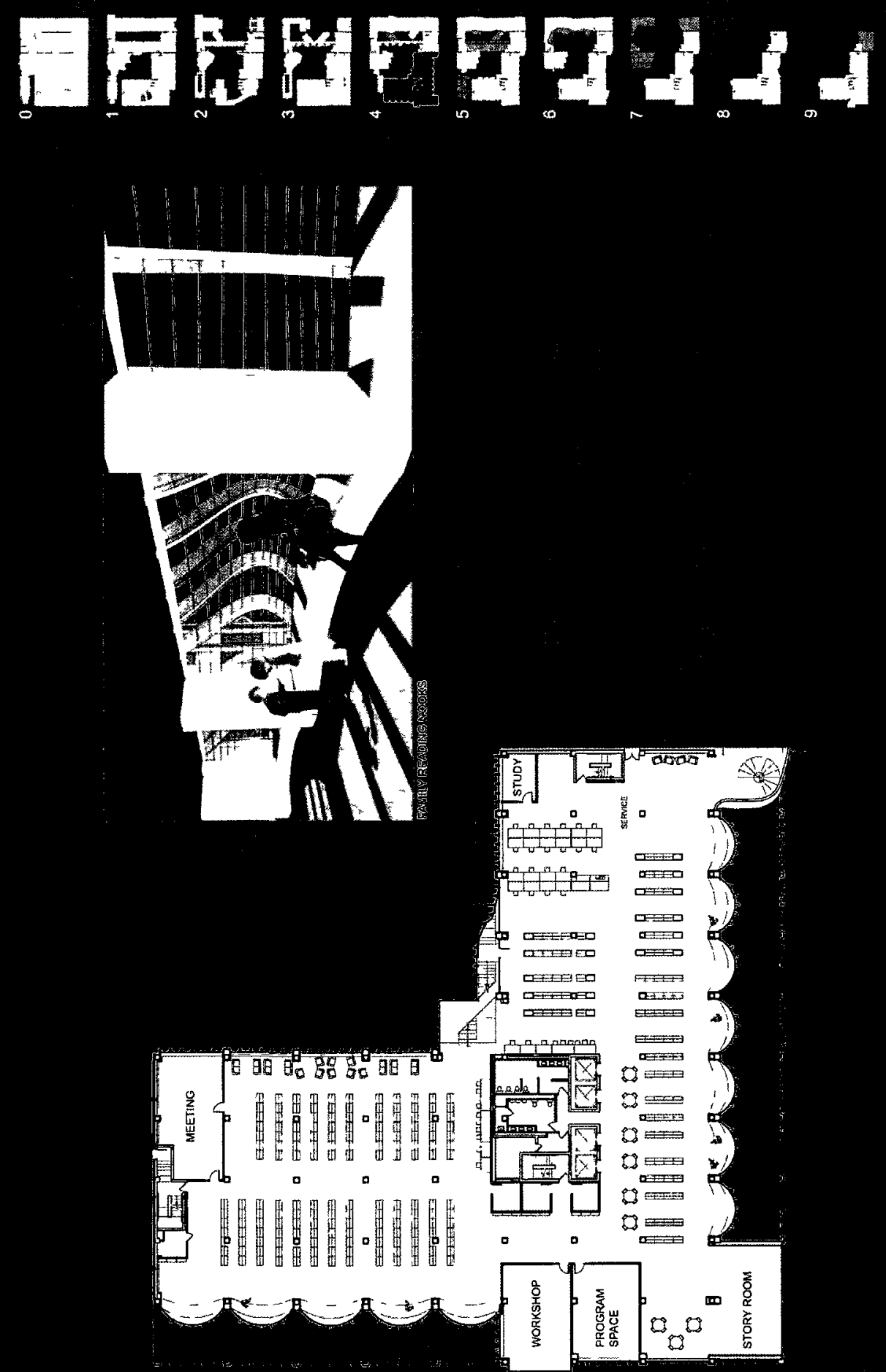

$\forall$ 
[Fiction, Newspapers \& Magazines Plan and Perspective]
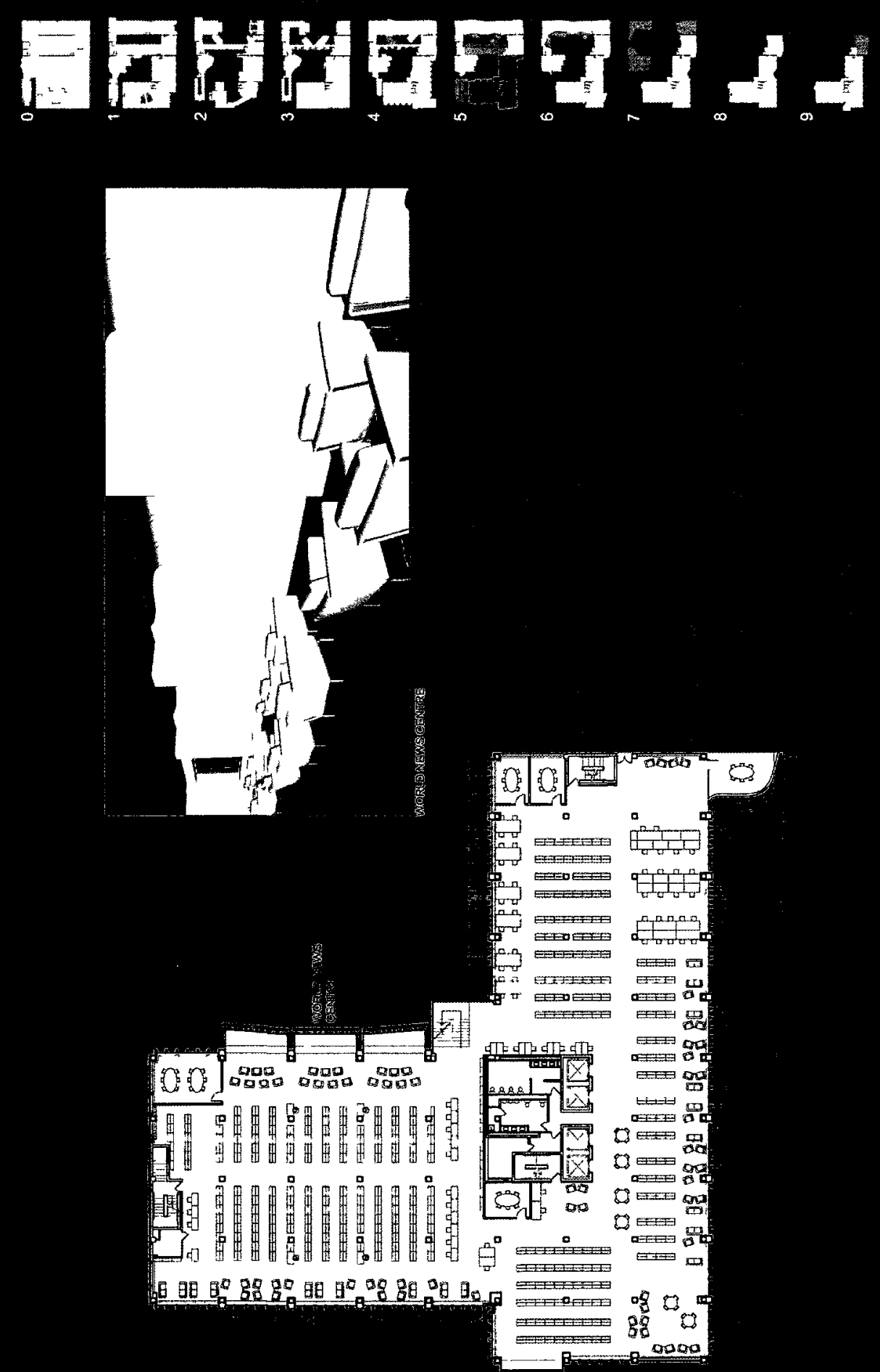

10 


\section{[Non-Fiction A Plan and Perspective]}

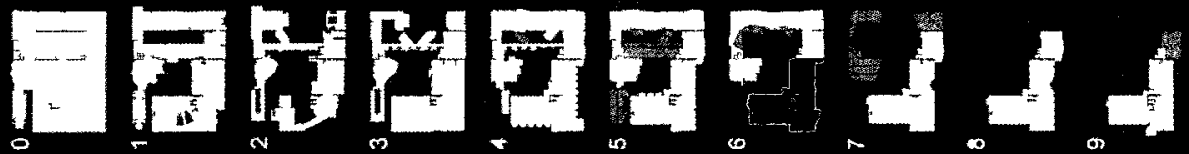
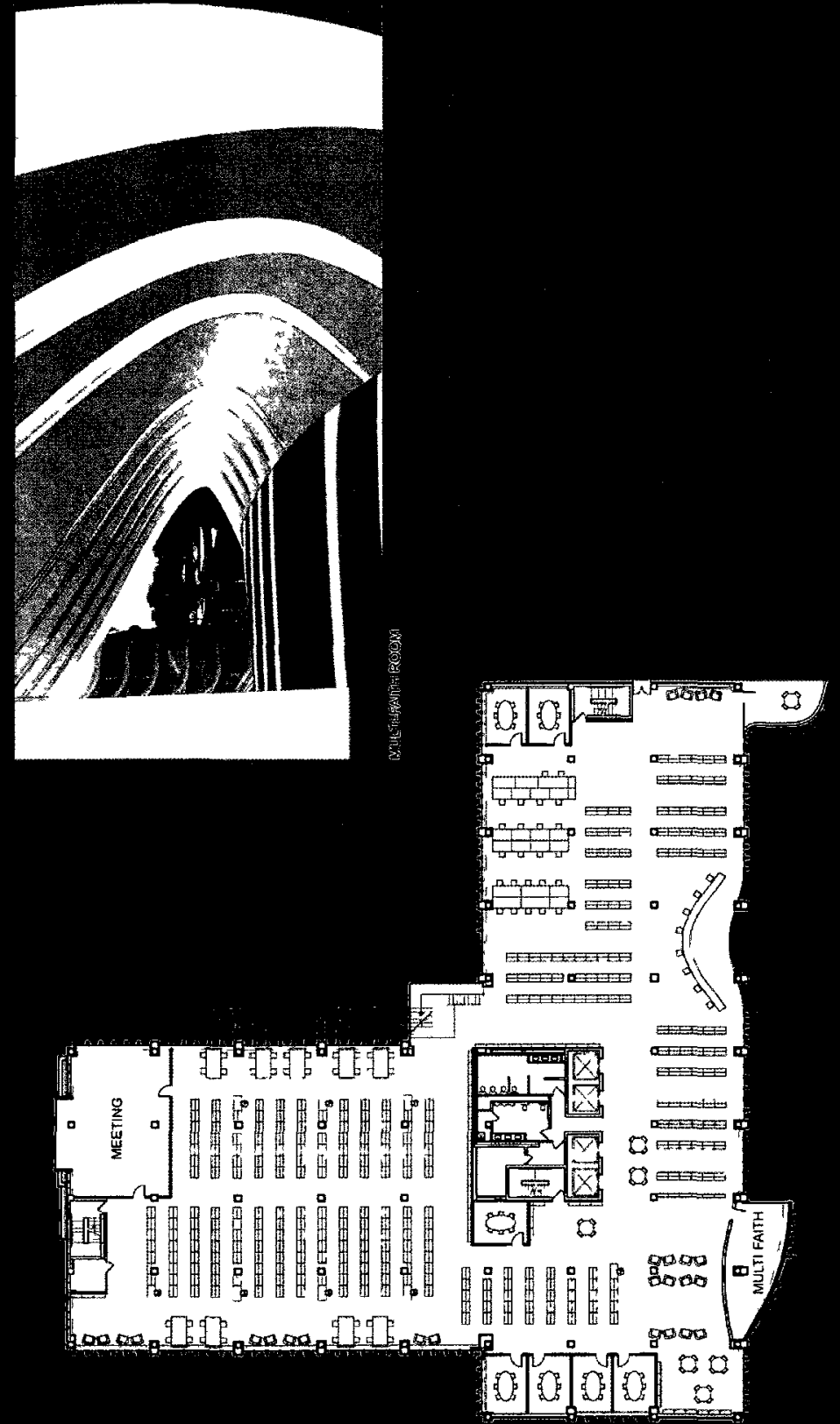

$\boldsymbol{\infty}$ 
[Non-Fiction B Plan and Perspective]
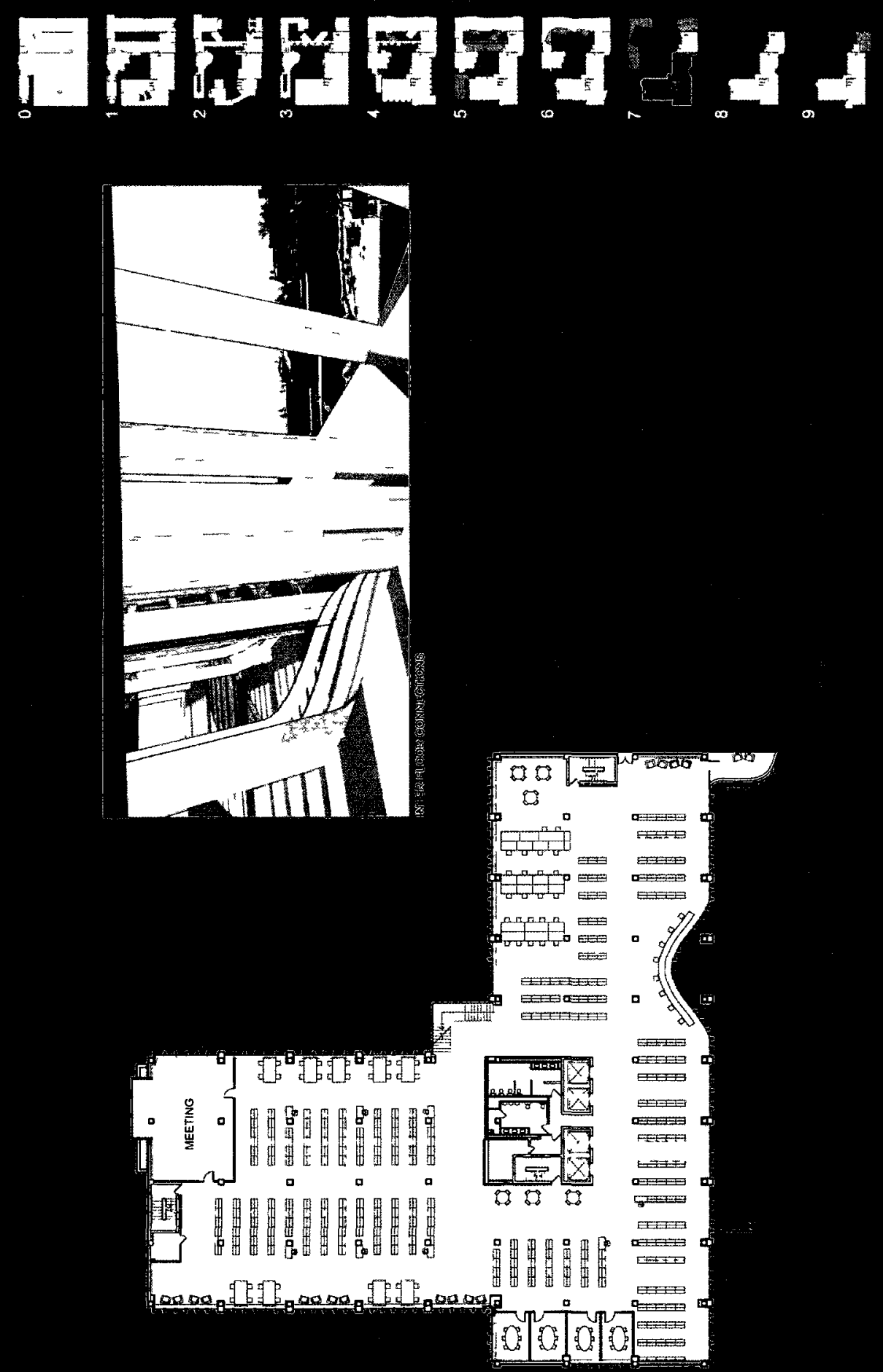

$N$ 


\section{[Non-Fiction C Plan]}
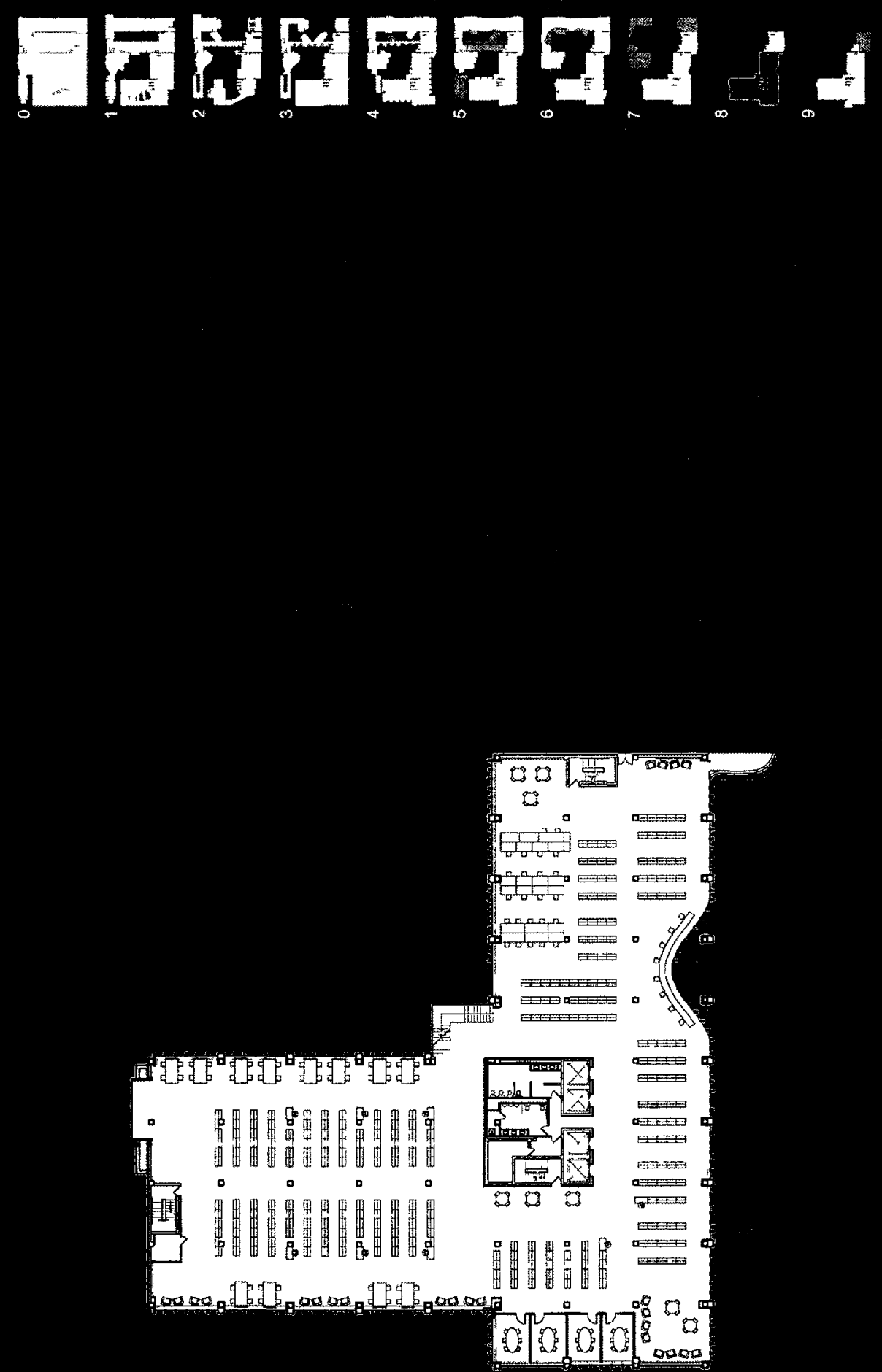

$\infty$ 


\section{[Administration Plan and Perspective]}

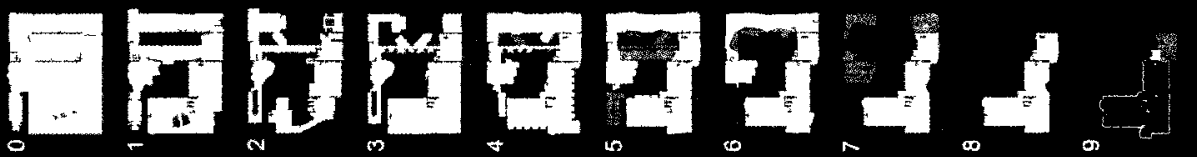

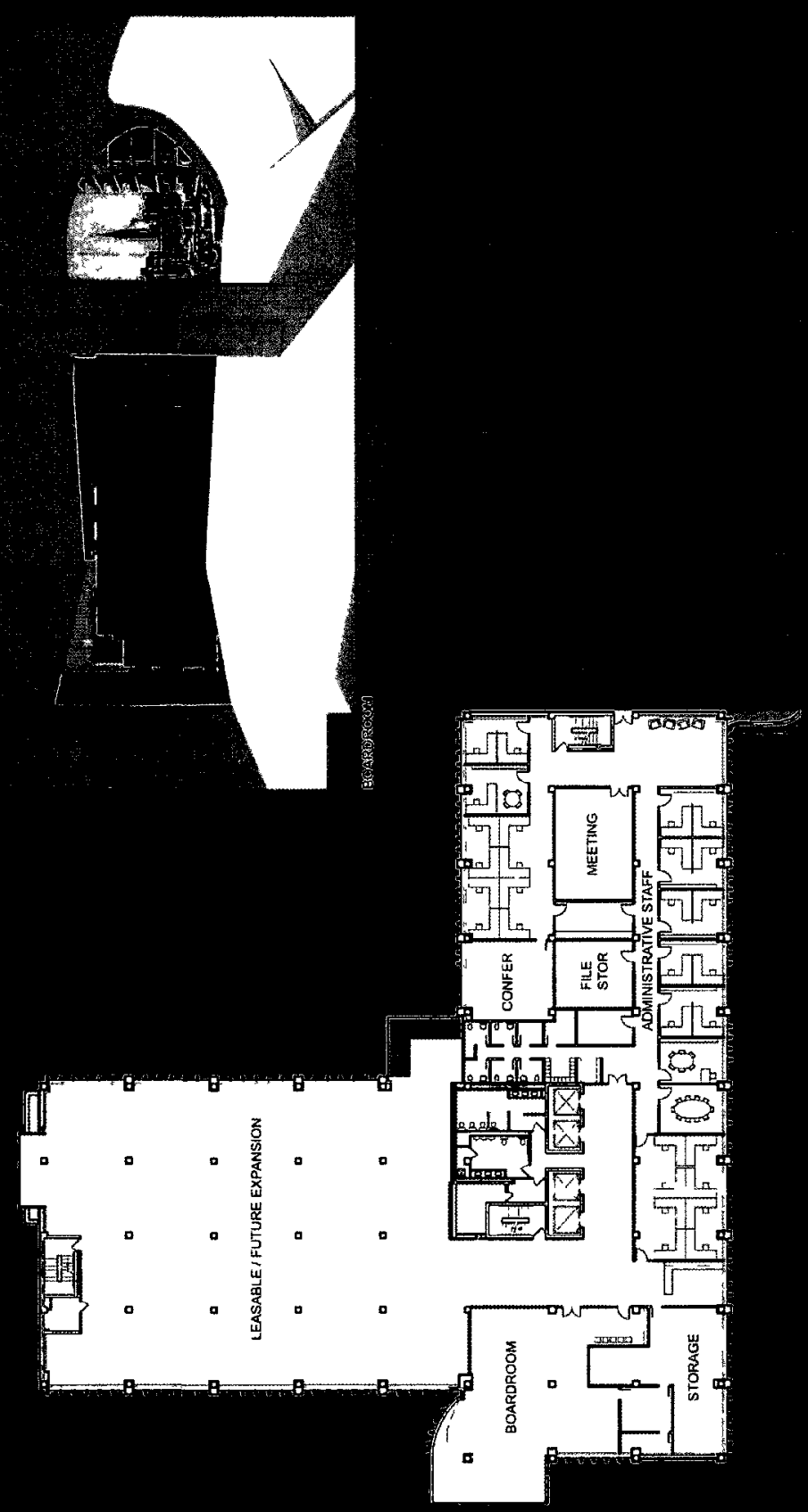

の) 
[Media \& Technology Centre Plans and Perspective]
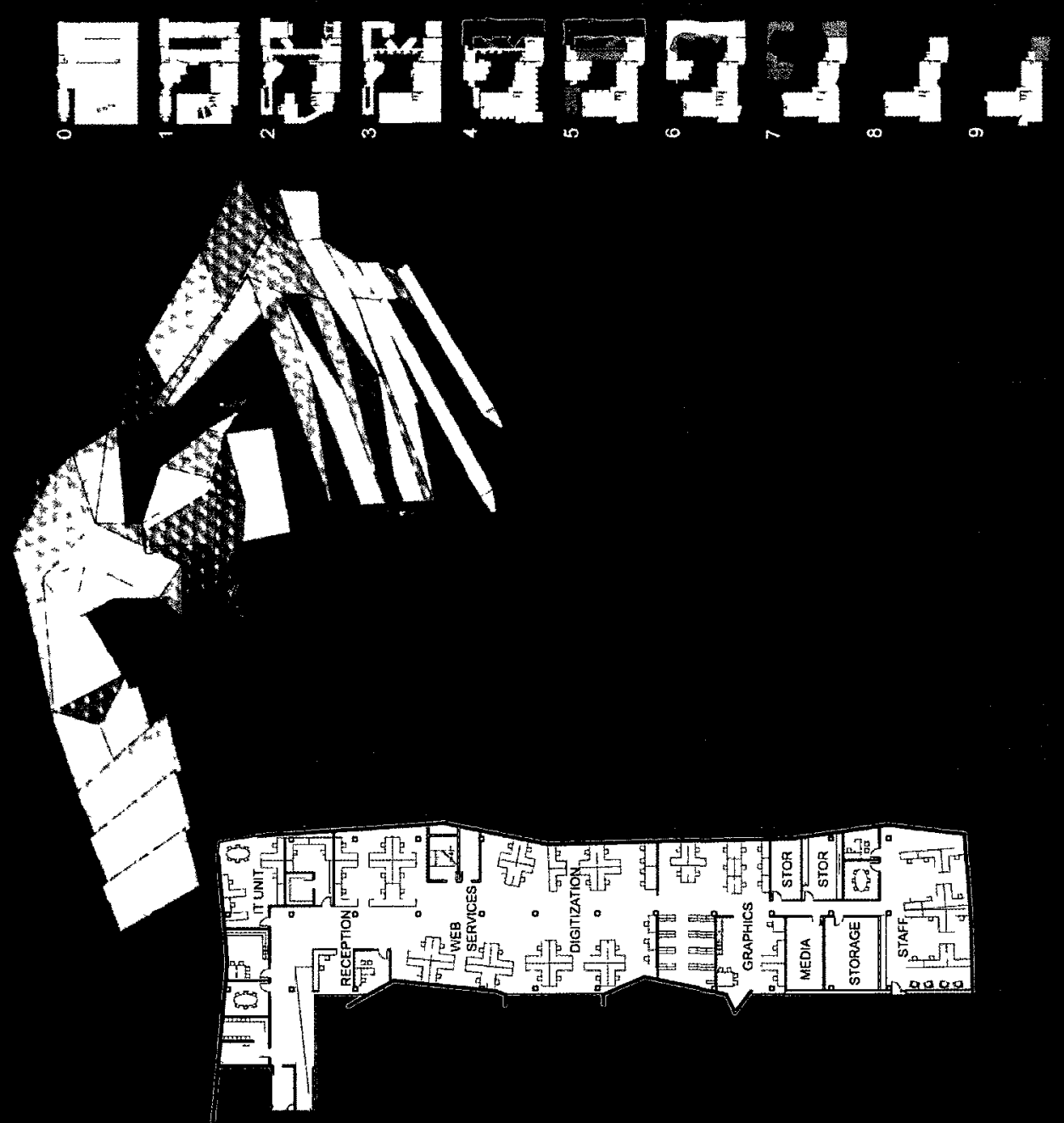

10

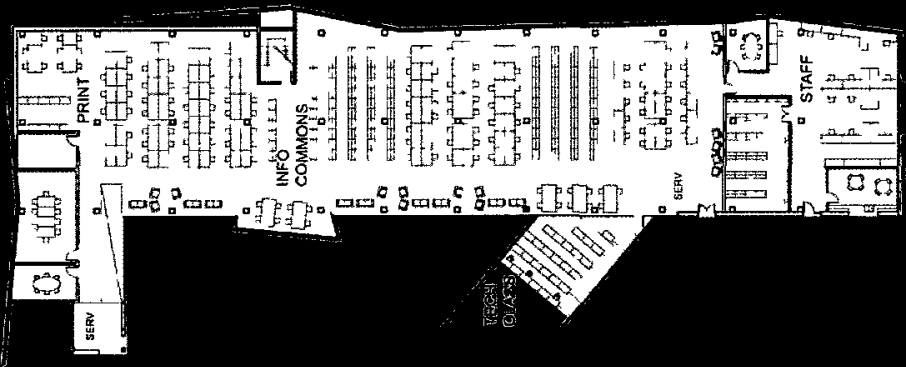

寸 


\section{[Library Staff Spaces Plans]}

\section{Gadrogidid}
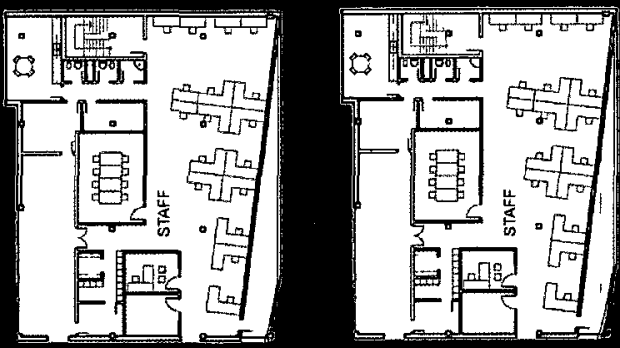

$N$

Q9)

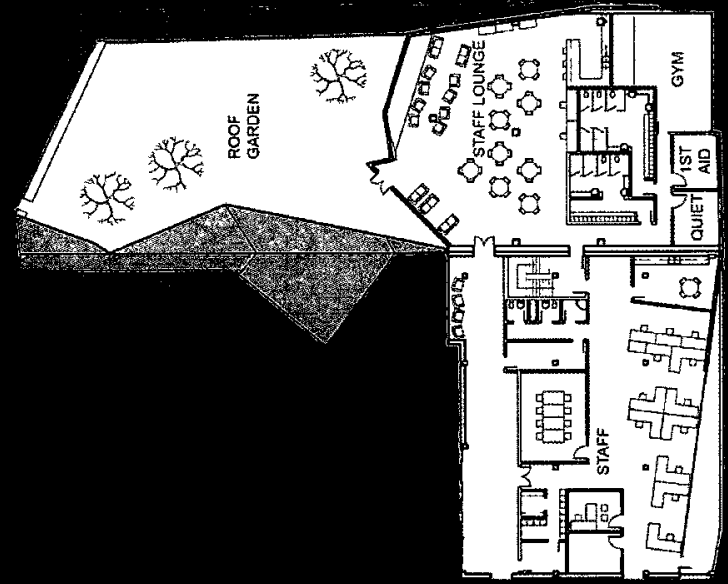

10
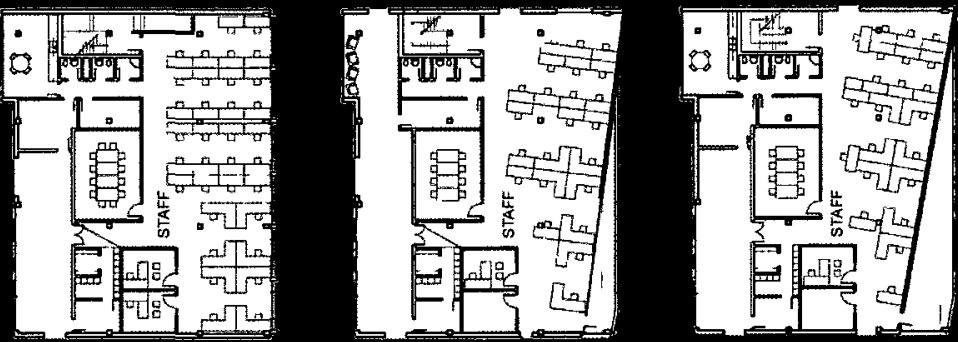

a)

$\forall$

4 
[Library Staff Spaces Perspective]
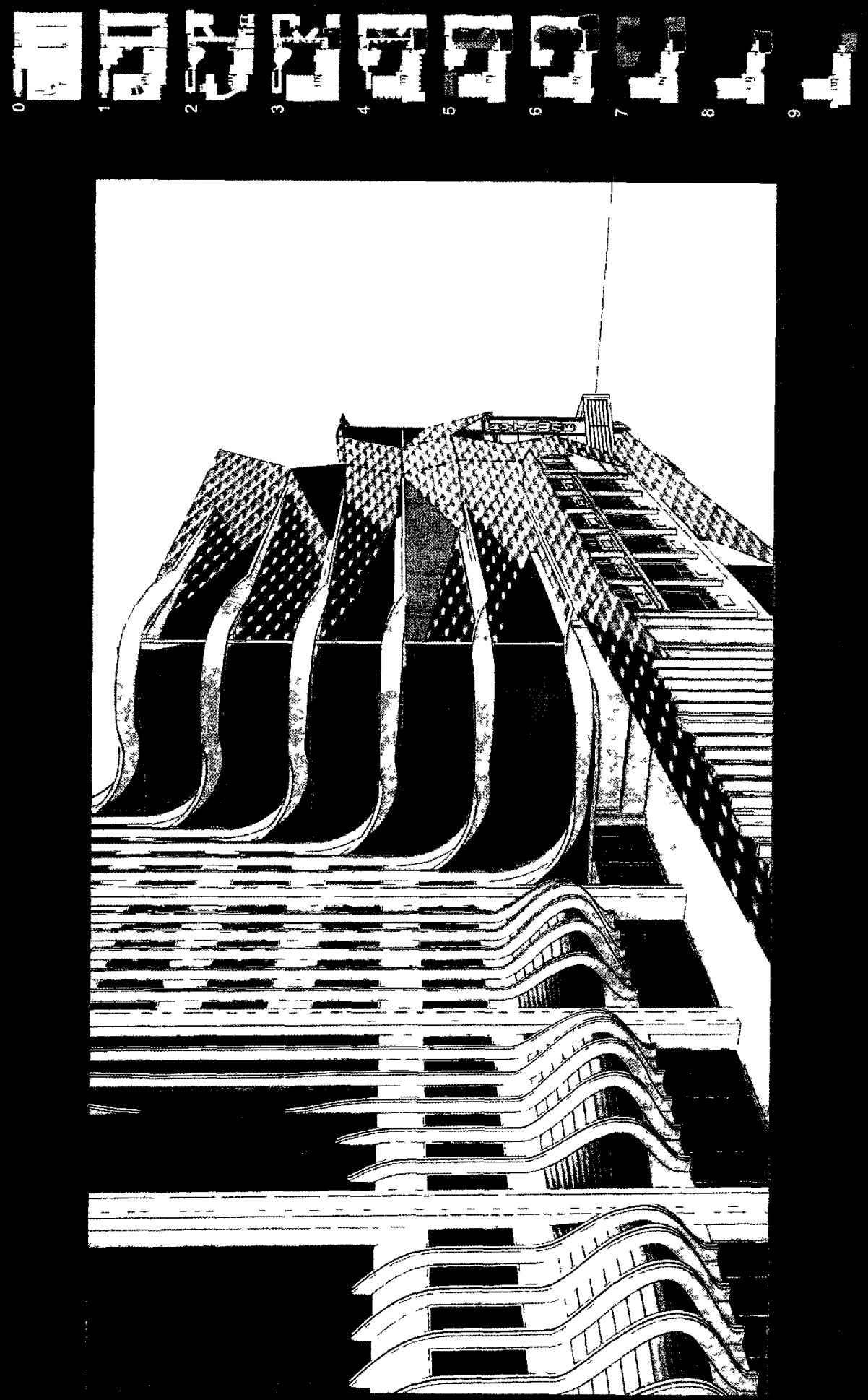
[Materials Handling \& Operations Plan]

\section{Badgagad}
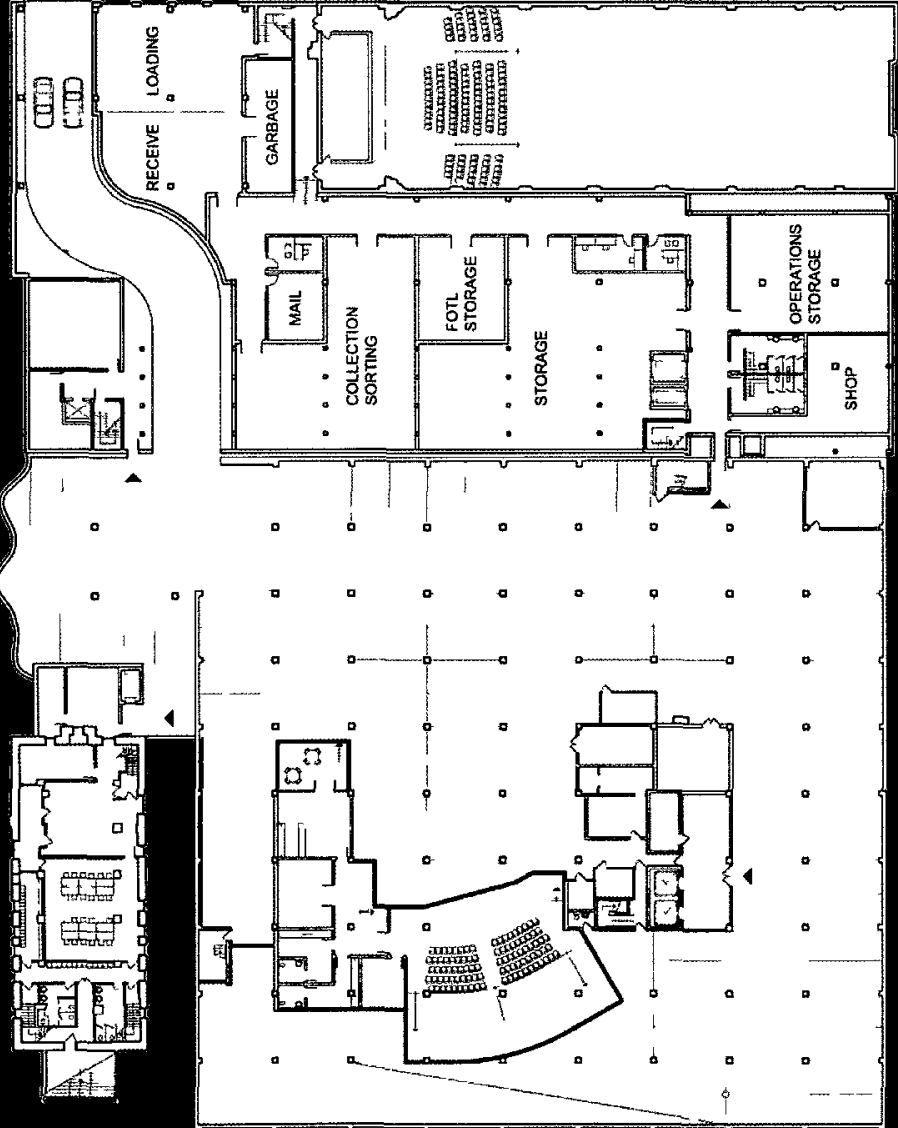

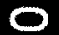


[Section Facing South]

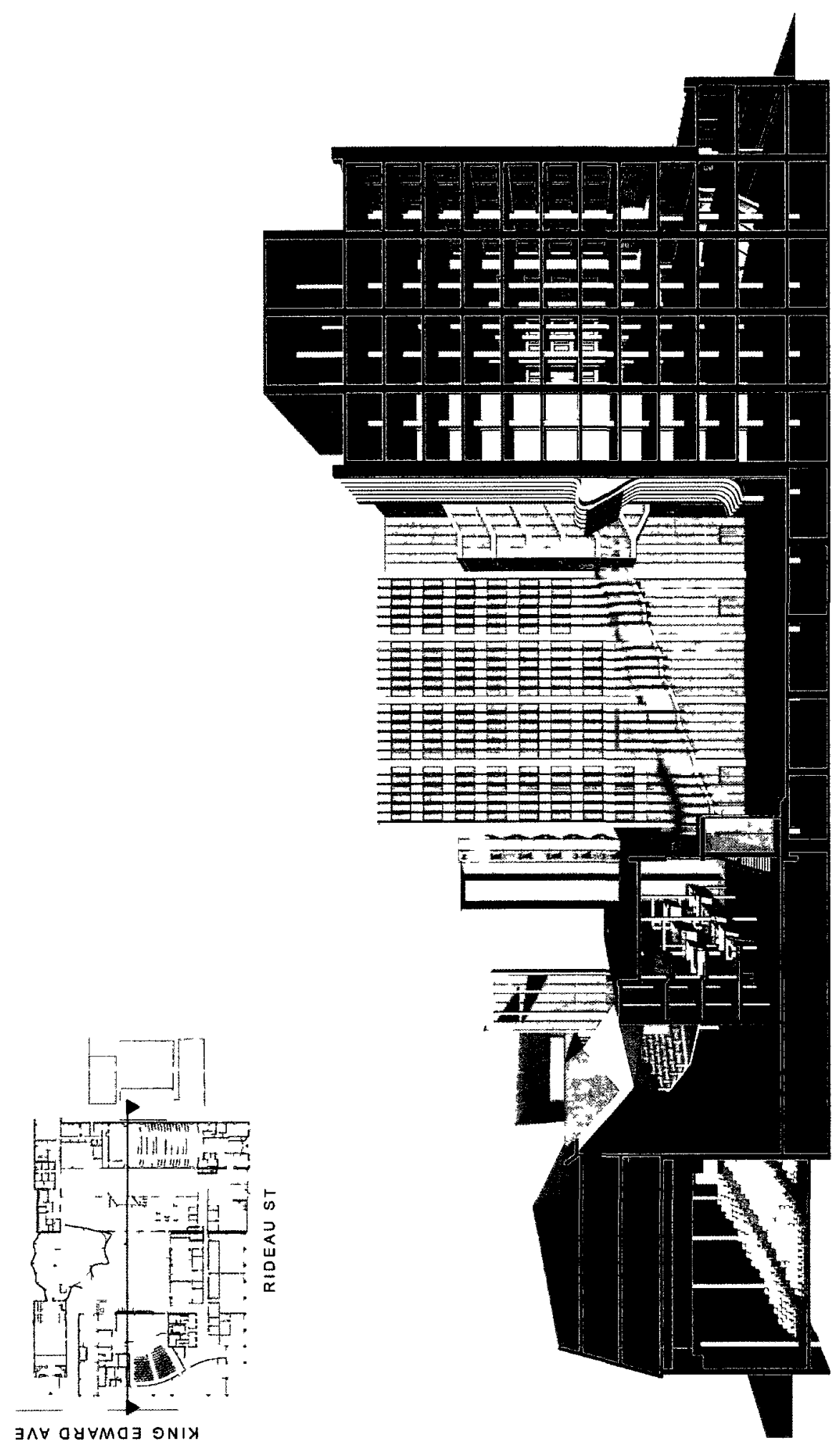




\section{[Section Facing North]}
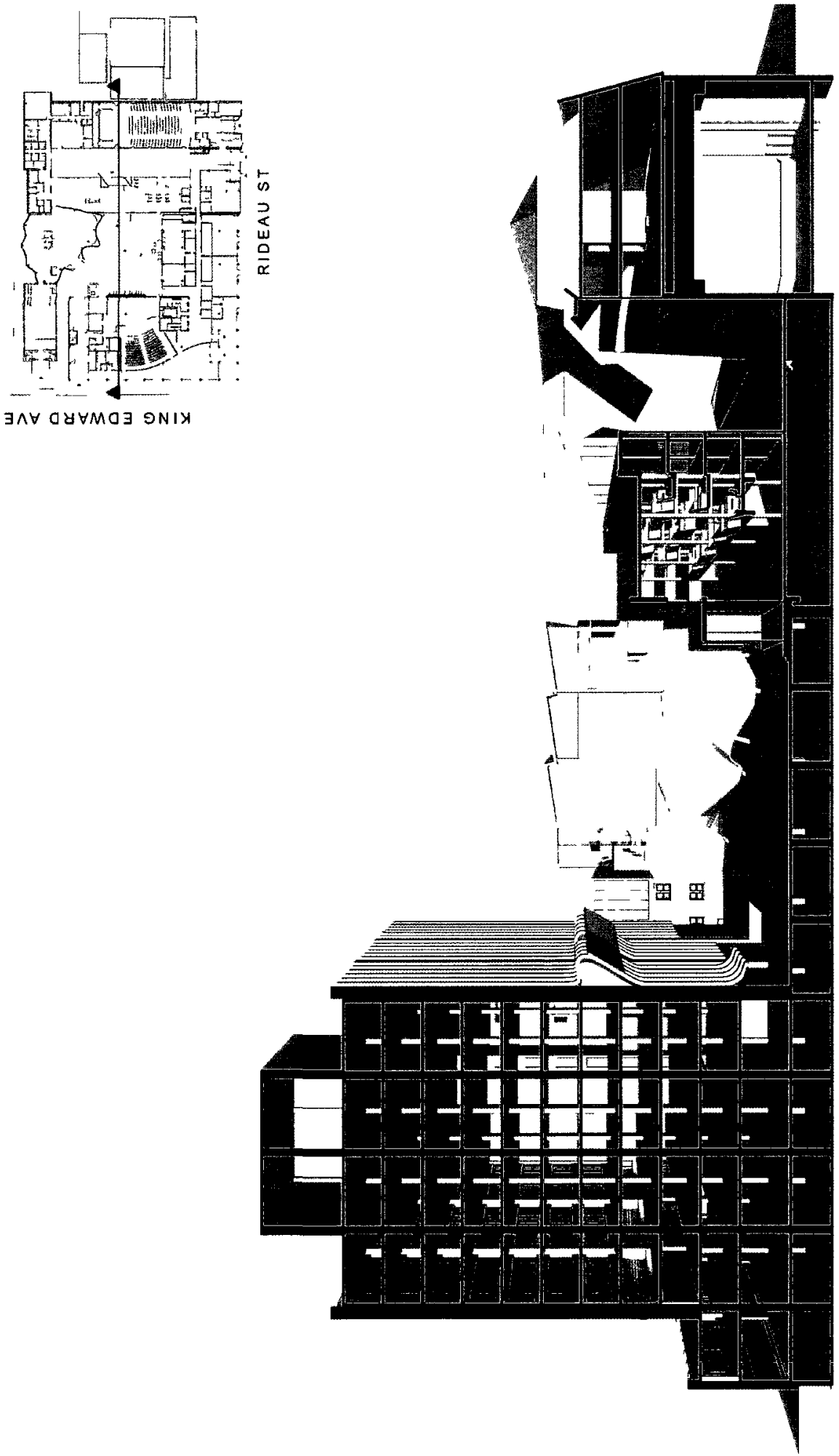
[Interior Perspective]

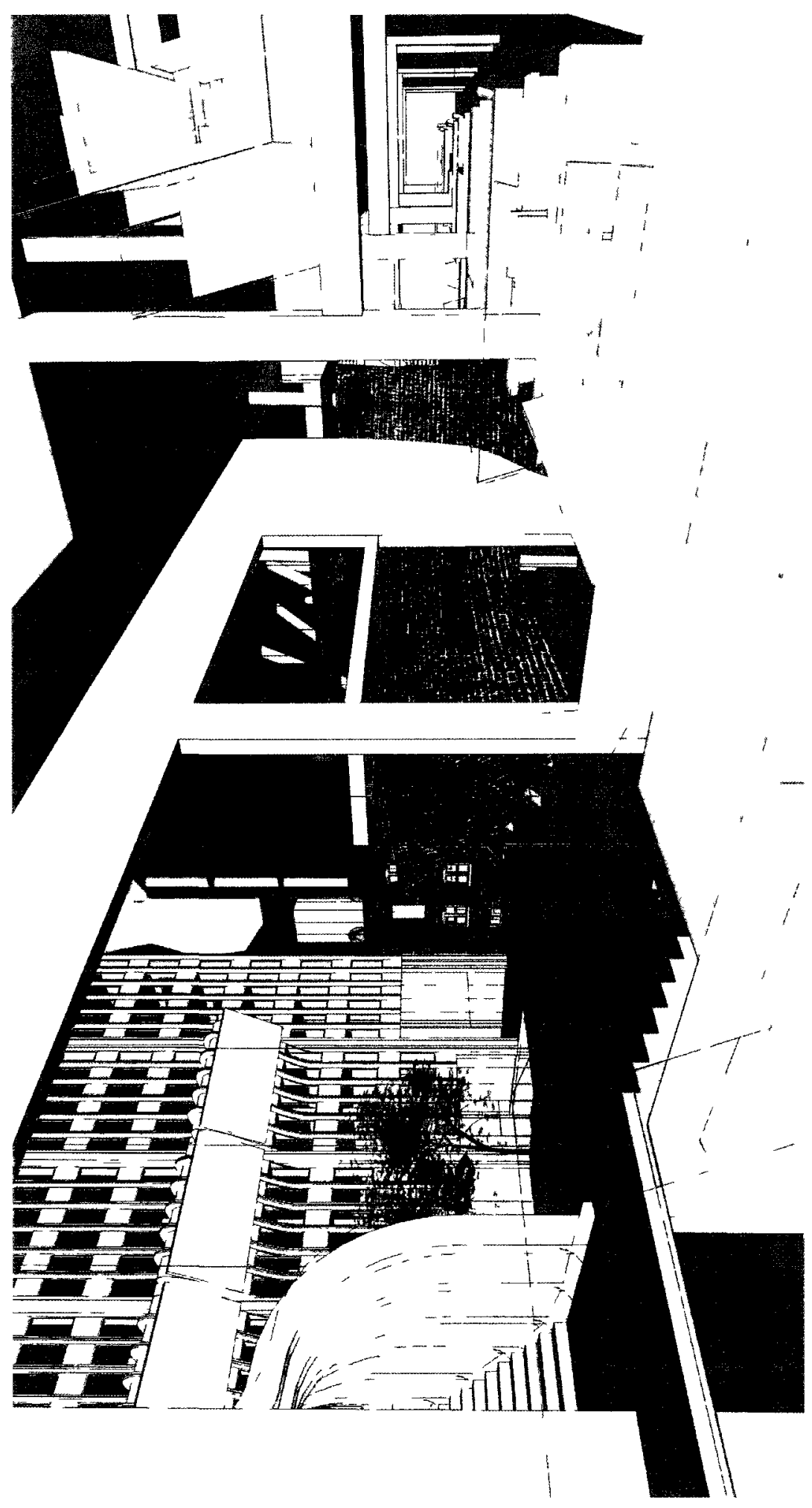

